\title{
Special Analysis for the Disposal of the Consolidated Edison Uranium Solidification Project Waste Stream at the Area 5 Radioactive Waste Management Site, Nevada National Security Site, Nye County, Nevada
}

January 2013

Prepared by

National Security Technologies, LLC

Las Vegas, Nevada

\section{Natlonal Securlty Technologles Lce

Prepared for

U.S. Department of Energy

National Nuclear Security Administration

Nevada Site Office

Under Contract Number DE-AC52-06NA25946 


\section{DISCLAIMER}

Reference herein to any specific commercial product, process, or service by trade name, trademark, manufacturer, or otherwise does not necessarily constitute or imply its endorsement, recommendation, or favoring by the United States Government or any agency thereof or its contractors or subcontractors.

Available for sale to the public, in paper, from:

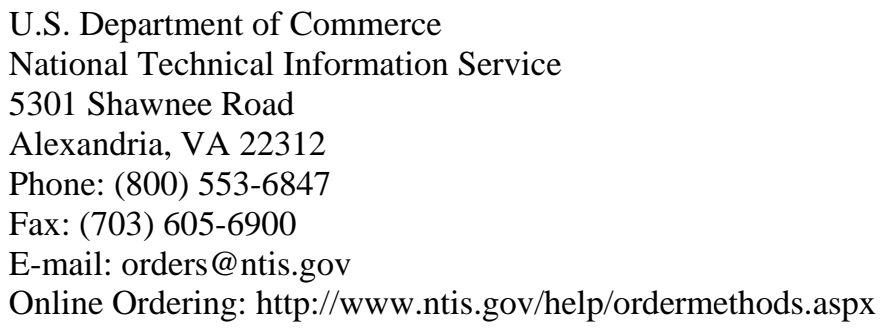

Available electronically at http://www.osti.gov/bridge

Available for a processing fee to the U.S. Department of Energy and its contractors, in paper, from:

U.S. Department of Energy

Office of Scientific and Technical Information

P.O. Box 62

Oak Ridge, TN 37831-0062

Phone: (865) 576-8401

Fax: (865) 576-5728

E-mail: reports@adonis.osti.gov 


\title{
Special Analysis for the Disposal of the Consolidated Edison Uranium Solidification Project Waste Stream at the Area 5 Radioactive Waste Management Site, Nevada National Security Site, Nye County, Nevada
}

January 2013

\author{
Prepared by \\ National Security Technologies, LLC \\ Las Vegas, Nevada
}

Prepared for

U.S. Department of Energy

National Nuclear Security Administration

Nevada Site Office

Under Contract Number DE-AC52-06NA25946 
This Page Intentionally Left Blank 


\section{Executive Summary}

The purpose of this Special Analysis (SA) is to determine if the Oak Ridge (OR) Consolidated Edison Uranium Solidification Project (CEUSP) uranium-233 $\left({ }^{233} \mathrm{U}\right)$ waste stream (DRTK000000050, Revision 0) is acceptable for shallow land burial (SLB) at the Area 5 Radioactive Waste Management Site (RWMS) on the Nevada National Security Site (NNSS). The CEUSP ${ }^{233} \mathrm{U}$ waste stream requires a special analysis because the concentrations of thorium-229 $\left({ }^{229} \mathrm{Th}\right),{ }^{230} \mathrm{Th},{ }^{232} \mathrm{U},{ }^{233} \mathrm{U}$, and ${ }^{234} \mathrm{U}$ exceeded their NNSS Waste Acceptance Criteria action levels. The acceptability of the waste stream is evaluated by determining if performance assessment (PA) modeling provides a reasonable expectation that SLB disposal is protective of human health and the environment.

The CEUSP ${ }^{233} \mathrm{U}$ waste stream is a long-lived waste with unique radiological hazards. The SA evaluates the long-term acceptability of the CEUSP ${ }^{233} \mathrm{U}$ waste stream for near-surface disposal as a two tier process. The first tier, which is the usual SA process, uses the approved probabilistic PA model to determine if there is a reasonable expectation that disposal of the CEUSP ${ }^{233} \mathrm{U}$ waste stream can meet the performance objectives of U.S. Department of Energy Manual DOE M 435.1-1, "Radioactive Waste Management,” for a period of 1,000 years (y) after closure. The second tier addresses the acceptability of the OR CEUSP ${ }^{233} \mathrm{U}$ waste stream for near-surface disposal by evaluating long-term site stability and security, by performing extended (i.e., 10,000 and 60,000 y) modeling analyses, and by evaluating the effect of containers and the depth of burial on performance.

Tier I results indicate that there is a reasonable expectation of compliance with all performance objectives if the OR CEUSP ${ }^{233} \mathrm{U}$ waste stream is disposed in the Area 5 RWMS SLB disposal units. The maximum mean and $95^{\text {th }}$ percentile PA results are all less than the performance objective for 1,000 y. Monte Carlo uncertainty analysis indicates that there is a high likelihood of compliance with all performance objectives.

Tier II results indicate that the long-term performance of the OR CEUSP ${ }^{233} \mathrm{U}$ waste stream is protective of human health and the environment. The Area 5 RWMS is located in one of the least populated and most arid regions of the U.S. Site characterization data indicate that infiltration of precipitation below the plant root zone at 2.5 meters ( 8.2 feet) ceased 10,000 to 15,000 y ago. The site is not expected to have a groundwater pathway as long as the current arid climate persists. The national security mission of the NNSS and the location of the Area 5 RWMS within the Frenchman Flat Corrective Action Unit require that access controls and land use restrictions be maintained indefinitely.

PA modeling results for 10,000 to $60,000 \mathrm{y}$ also indicate that the OR CEUSP ${ }^{233} \mathrm{U}$ waste stream is acceptable for near-surface disposal. The mean resident air pathway annual total effective dose (TED), the resident all-pathways annual TED, and the acute drilling TED are less than their performance objectives for $10,000 \mathrm{y}$ after closure. The mean radon-222 $\left({ }^{222} \mathrm{Rn}\right)$ flux density exceeds the performance objective at 4,200 y, but this is due to waste already disposed at the Area 5 RWMS and is only slightly affected by disposal of the CEUSP ${ }^{233} \mathrm{U}$. The peak resident 
all-pathways annual TED from CEUSP key radionuclides occurs at 48,000 y and is less than the 0.25 millisievert performance objective.

Disposal of the OR CEUSP ${ }^{233} \mathrm{U}$ waste stream in a typical SLB trench slightly increases PA results. Increasing the depth was found to eliminate any impacts of the OR CEUSP ${ }^{233} \mathrm{U}$ waste stream. Containers could not be shown to have any significant impact on performance due to the long half-life of the waste stream and a lack of data for pitting corrosion rates of stainless steel in soil.

The results of the SA indicate that all performance objectives can be met with disposal of the OR CEUSP ${ }^{233} \mathrm{U}$ waste stream in the SLB units at the Area 5 RWMS. The long-term performance of the OR CEUSP ${ }^{233} \mathrm{U}$ waste stream disposed in the near surface is protective of human health and the environment. The waste stream is recommended for disposal without conditions. 


\section{Table of Contents}

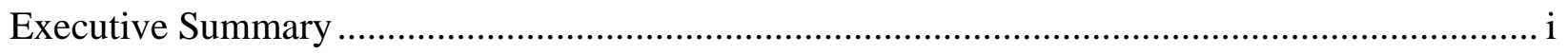

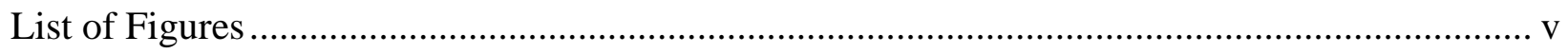

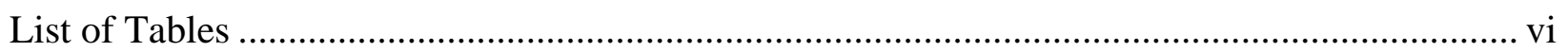

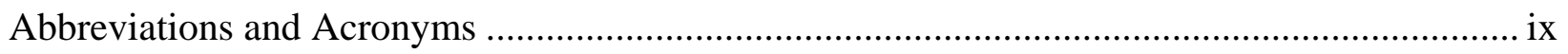

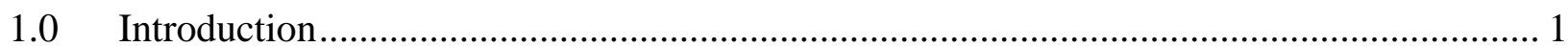

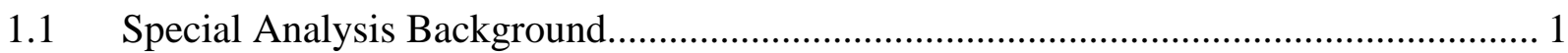

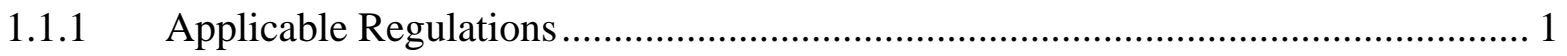

1.1.2 Special Characteristics of CEUSP ${ }^{233} \mathrm{U}$ Waste Stream ........................................... 2

1.1.3 Special Analysis Approach .................................................................................... 2

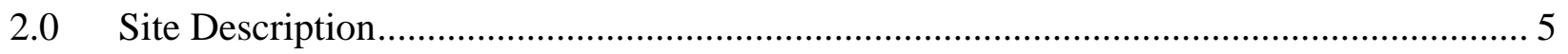

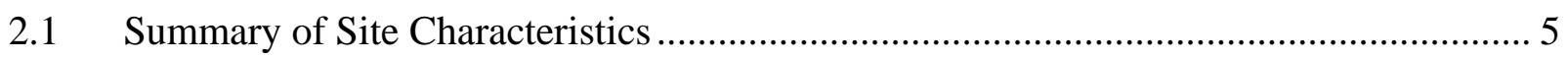

2.2 Future Site Characteristics ................................................................................... 5

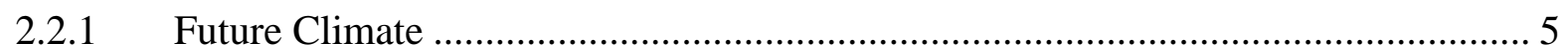

2.2.2 Future Hydrologic Conditions ……………….................................................... 7

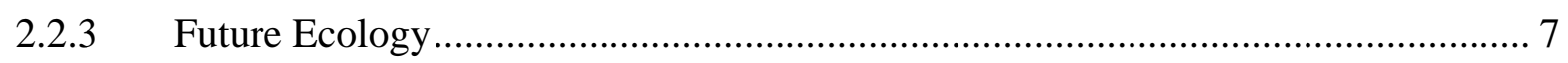

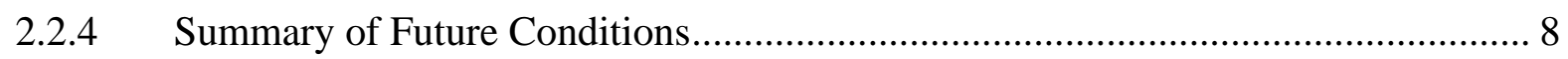

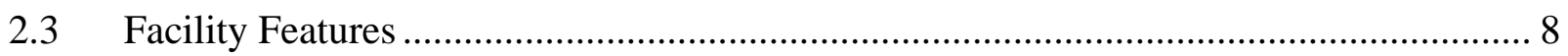

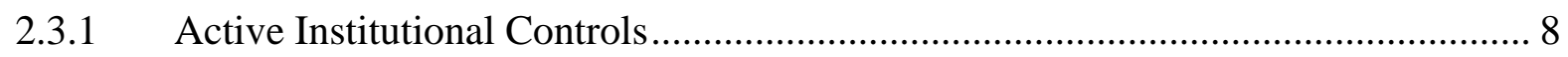

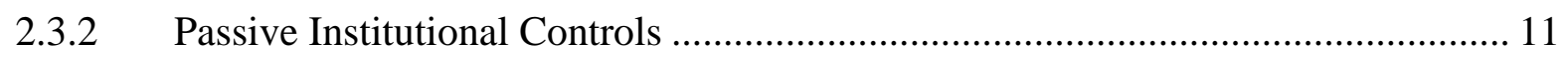

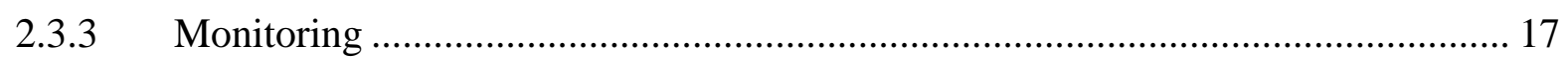

2.3.4 Natural and Engineered Barriers..................................................................... 19

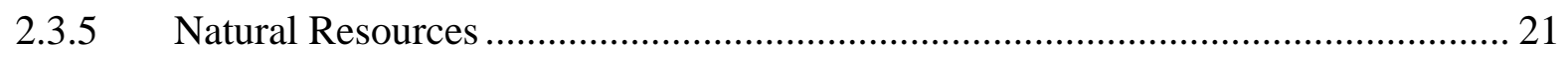

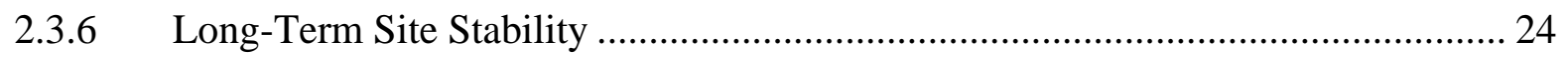

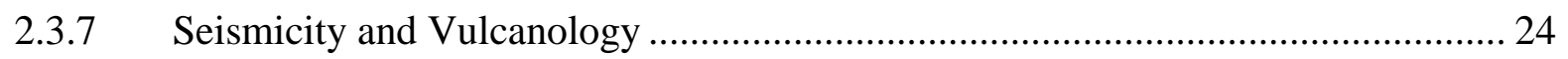

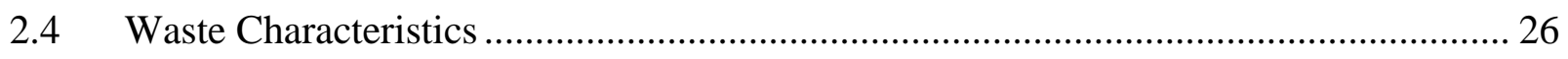

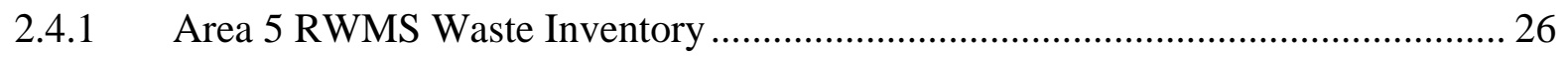

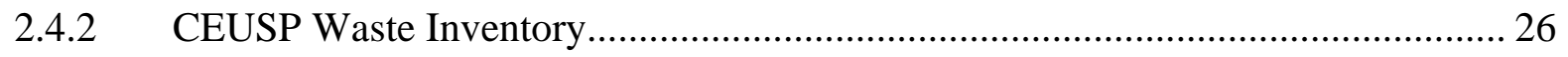

2.4.3 CEUSP Waste Form and Containers ……………............................................ 28

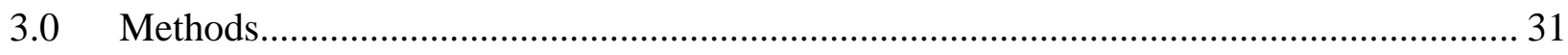

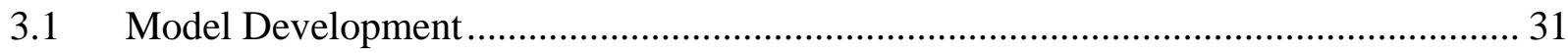

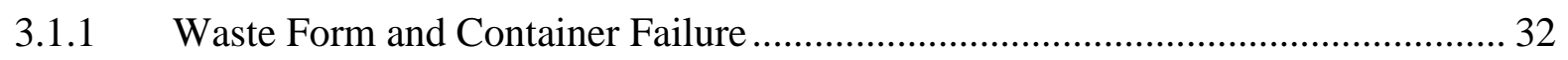

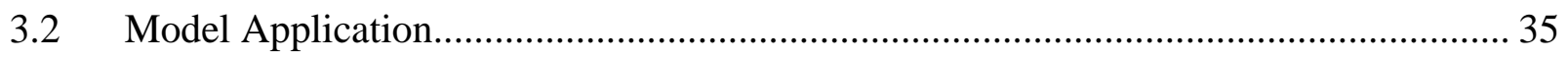


4.0 Tier I Results: Performance Assessment ................................................................ 37

4.1 Performance Assessment Results ....................................................................... 37

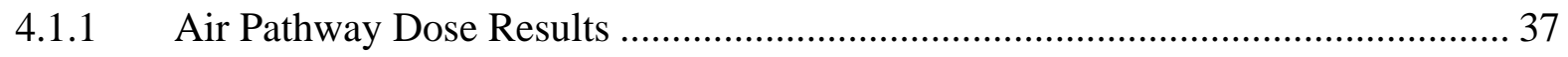

4.1.2 All-Pathways Dose Results.......................................................................... 39

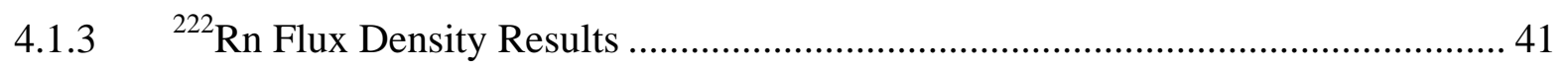

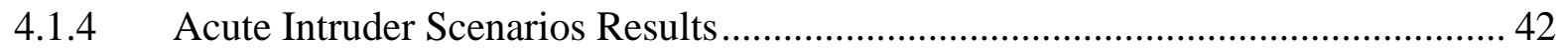

4.2 Performance Assessment Uncertainty Analysis.................................................... 44

4.2.1 Air Pathway Dose Uncertainty ................................................................... 44

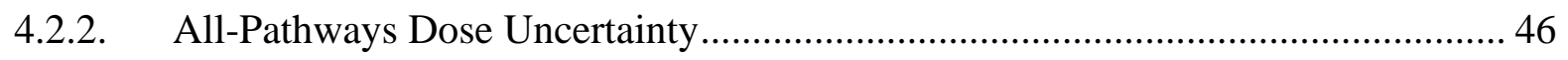

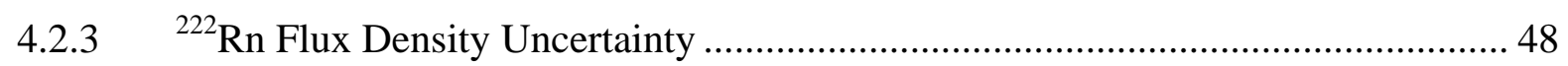

5.0 Tier II: Assessing Long-Term Acceptability for Near-Surface Disposal ........................ 51

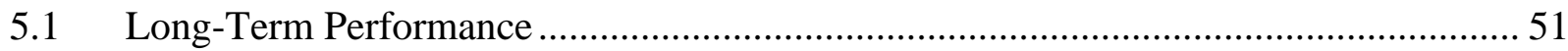

5.1.1 Air Pathway Long-Term Performance............................................................ 51

5.1.2 All-Pathways Long-Term Performance ........................................................... 52

5.1.3 Peak CEUSP Waste Stream All-Pathways Dose ................................................. 54

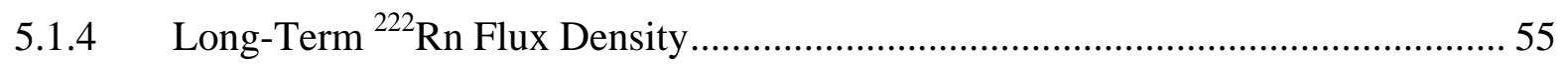

5.1.5 Long-Term Intruder Results ...................................................................... 56

5.2 Long-Term Effects of Containers and Depth of Burial........................................... 57

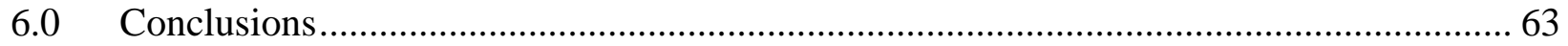

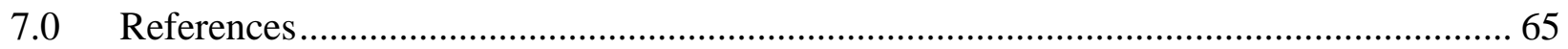

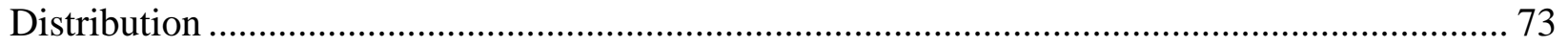




\section{List of Figures}

Figure 2.1 Ownership of lands surrounding the NNSS 12

Figure 2.2 Inventory time history of long-lived radionuclides in the CEUSP ${ }^{233} \mathrm{U}$ waste stream.... 28

Figure 4.1 Air pathway annual TED time history for a resident at the 100-m site boundary....... 38 Figure 4.2 Resident air pathway annual TED time history by radionuclide.............................. 39 Figure 4.3 All-pathways annual TED time history for a resident at the 100-m site boundary ..... 40 Figure 4.4 Resident all-pathway annual TED time history by radionuclide............................. 41 Figure $4.5{ }^{222} \mathrm{Rn}$ flux density time history averaged over all disposal units.............................. 42 Figure 4.6 Acute intruder TED time history for the drilling intruder scenario at a SLB disposal

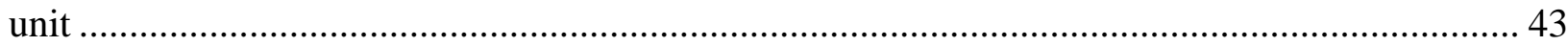

Figure 4.7 Acute drilling intruder TED time history by radionuclide ................................... 44

Figure 4.8 Histogram of non-zero values and ecdf of the resident air pathway annual TED at

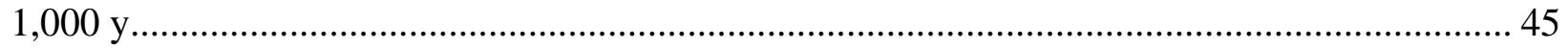

Figure 4.9 Air pathway annual TED time histories for alternative scenarios............................ 46

Figure 4.10 Histogram of non-zero values and ecdf of the resident all-pathways annual TED at

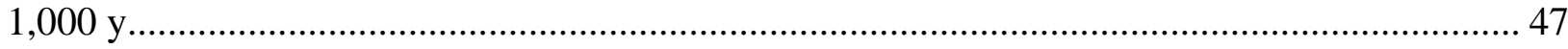

Figure 4.11 All-pathways annual TED time histories for alternative scenarios ........................ 48 Figure 4.12 Histogram and ecdf of the ${ }^{222}$ Rn flux density averaged over the Area 5 RWMS at

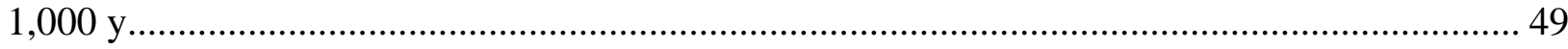

Figure 5.1 Resident air pathway annual TED time history over 10,000 y................................ 52

Figure 5.2 Resident all-pathways annual TED time history over 10,000 y …........................... 53

Figure 5.3 Resident all-pathways annual TED by radionuclide over 60,000 y......................... 55

Figure $5.4{ }^{222} \mathrm{Rn}$ flux density time history over 10,000 y ................................................... 56

Figure 5.5 Acute drilling intruder TED time history over 10,000 y ….................................... 57

Figure 5.6 Comparison of resident air pathway annual TED time histories over 10,000 y for

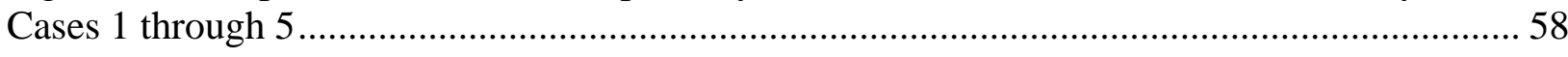

Figure 5.7 Comparison of resident all-pathways annual TED time histories over 10,000 y for

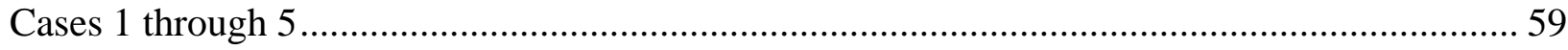

Figure 5.8 Time history of the ${ }^{222} \mathrm{Rn}$ flux density over 10,000 y for Cases 1 through 5 ............. 60 Figure 5.9 Boxplots of the resident all-pathways annual TED at 10,000 y for Cases 1 through 5... 


\section{List of Tables}

Table 2.1 Summary of future climate states forecast for southern Nevada by the YMP 6

Table 2.2 Mean annual precipitation and temperature for current and future climate conditions as assumed by the YMP

Table 2.3 Mean annual precipitation and temperature for current and future climate regimes for Frenchman Flat

Table 2.4 OR CEUSP waste stream geometric means and geometric standard deviations at the time of disposal.....

Table 2.5 General corrosion rates for steel buried in arid vadose zone soils at the Idaho National

Laboratory 29

Table 2.6 Maximum radon gas production in CEUSP canisters ............................................. 30

Table 3.1 Carbon steel pitting model parameters ................................................................ 33

Table 3.2 Statistics for time to failure, y, for the CEUSP disposal sleeve and stainless steel

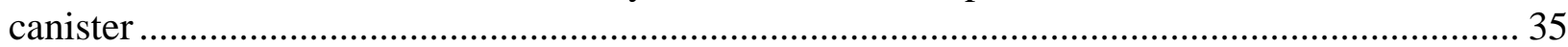

Table 3.3 Description of modeling cases evaluated in the SA .............................................. 35

Table 4.1 Resident air pathway annual TED for the FY 2011 Area 5 RWMS Inventory with and

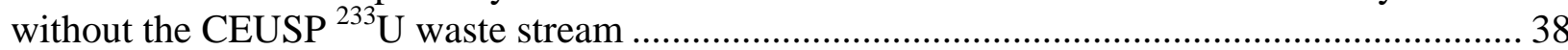

Table 4.2 Resident all-pathways annual TED for the FY 2011 Area 5 RWMS Inventory with and

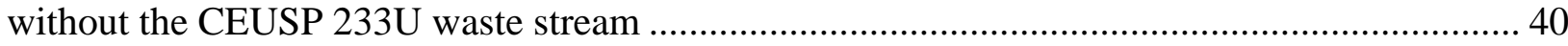

Table 4.3 222Rn flux density for the FY 2011 Area 5 RWMS Inventory with and without the

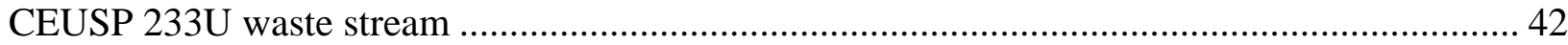

Table 4.4 Acute drilling TED for the FY 2011 Area 5 RWMS Inventory with and without the CEUSP 233U waste stream

Table 4.5 Alternative scenario air pathway TED for the FY 2011 Area 5 RWMS Inventory with

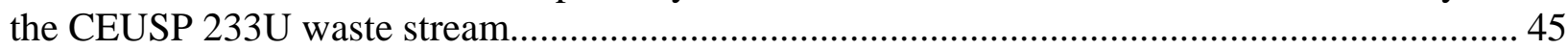

Table 4.6 Alternative scenario all-pathways TED for the FY 2011 Area 5 RWMS Inventory with

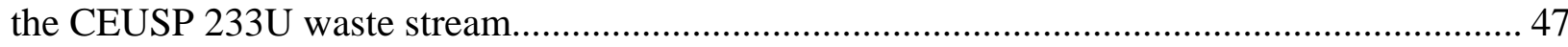

Table 5.1 Long-term air pathway results for the CEUSP ${ }^{233} \mathrm{U}$ waste stream averaged over the

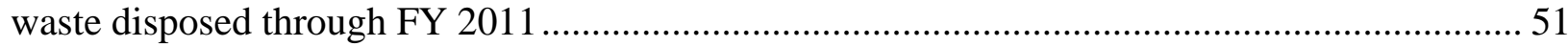

Table 5.2 Long-term air pathway results for the waste disposed through FY 2011 ................... 52

Table 5.3 Long-term all-pathways results for the CEUSP ${ }^{233} \mathrm{U}$ waste stream averaged over the

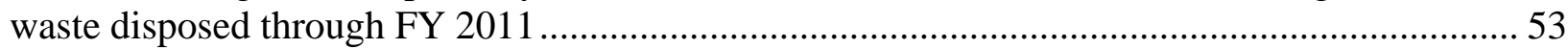

Table 5.4 Long-term all-pathways results for the waste disposed through FY 2011 ................. 54

Table 5.5 Long-term ${ }^{222} \mathrm{Rn}$ flux density for the CEUSP ${ }^{233} \mathrm{U}$ waste stream averaged over the

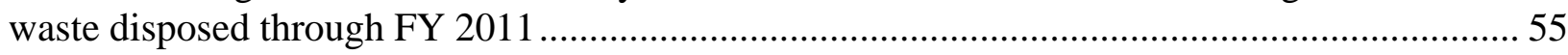

Table 5.6 Long-term acute drilling intruder results for the OR CEUSP ${ }^{233} \mathrm{U}$ waste stream averaged over the SLB waste disposed through FY 2011 56 
Table 5.7 Comparison of mean results for Cases 1 through 5 at 1,000 y ......................................6 60

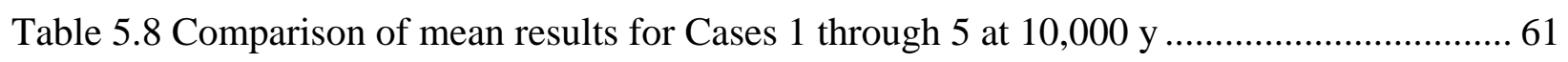

Table 6.1 Comparison of mean SA results with and without the OR CEUSP ${ }^{233} \mathrm{U}$ waste stream at

1,000 y 
This Page Intentionally Left Blank 


\section{Abbreviations and Acronyms}

\begin{tabular}{|c|c|}
\hline BLM & Bureau of Land Management \\
\hline $\mathrm{BN}$ & Bechtel Nevada \\
\hline $\mathrm{Bq}$ & becquerel(s) \\
\hline $\mathrm{Bq} \mathrm{m} \mathrm{m}^{-2} \mathrm{~s}^{-1}$ & becquerel(s) per square meter per second \\
\hline CAU & corrective action unit \\
\hline CEUSP & Consolidated Edison Uranium Solidification Project \\
\hline CFR & Code of Federal Regulations \\
\hline $\mathrm{cm}$ & centimeter(s) \\
\hline CR & closure report \\
\hline DoD & U.S. Department of Defense \\
\hline DOE & U.S. Department of Energy \\
\hline DOE/NV & U.S. Department of Energy, Nevada Operations Office \\
\hline ecdf & empirical cumulative distribution function \\
\hline EIS & Environmental Impact Statement \\
\hline ET & evapotranspirative \\
\hline FEPs & features, events, and processes \\
\hline $\begin{array}{l}\text { FFACO } \\
\mathrm{ft}\end{array}$ & $\begin{array}{l}\text { Federal Facility Agreement and Consent Order } \\
\text { foot(feet) }\end{array}$ \\
\hline FY & fiscal year \\
\hline g & $\operatorname{gram}(\mathrm{s})$ \\
\hline${ }^{3} \mathrm{H}$ & tritium \\
\hline ha & hectare(s) \\
\hline HLW & high-level radioactive waste \\
\hline $\begin{array}{l}\text { IC } \\
\text { in. }\end{array}$ & $\begin{array}{l}\text { institutional control } \\
\text { inch(es) }\end{array}$ \\
\hline $\mathrm{kg}$ & kilogram(s) \\
\hline $\mathrm{kg} \mathrm{ha}^{-1} \mathrm{y}^{-1}$ & kilogram(s) per hectare per year \\
\hline $\mathrm{km}$ & kilometer(s) \\
\hline $\mathrm{km}^{2}$ & square kilometer(s) \\
\hline LHS & Latin hypercube sampling \\
\hline LLW & low-level radioactive waste \\
\hline $\mathrm{m}$ & meter(s) \\
\hline Мa & million years ago \\
\hline $\mathrm{mi}$ & mile(s) \\
\hline
\end{tabular}




$\begin{array}{ll}\mathrm{mi}^{2} & \text { square mile(s) } \\ \mathrm{mm} & \text { millimeter(s) } \\ \mathrm{mSv} & \text { millisievert(s) }\end{array}$

$\mathrm{nCi} \mathrm{g}^{-1} \quad$ nanocurie per gram

NDEP Nevada Division of Environmental Protection

NNSA/NSO U.S. Department of Energy, National Nuclear Security Administration Nevada Site Office

NNSA/NV U.S. Department of Energy, Nevada Operations Office

NNSS Nevada National Security Site

NRC U.S. Nuclear Regulatory Commission

NSTec National Security Technologies, LLC

NTS Nevada Test Site

OR Oak Ridge

PA performance assessment

$\mathrm{Pb} \quad$ lead

pdf probability density function

RaDU radium disposal unit

RCRA Resource Conservation and Recovery Act

Rn radon

RWMS Radioactive Waste Management Site

S

second(s)

SA Special Analysis

SAIC Science Applications International Corporation

SLB shallow land burial

SME subject matter expert

SNF spent nuclear fuel

SPEIS Special Programmatic Environmental Impact Statement

TED total effective dose

Th thorium

TRU transuranic

$\mathrm{U} \quad$ uranium

$\mathrm{U}_{3} \mathrm{O}_{8} \quad$ uranium oxide

UGTA Underground Test Area

UNS Unified Numbering System

UR use restriction

y $\quad$ year(s)

YMP Yucca Mountain Project 


\subsection{Introduction}

The purpose of this Special Analysis (SA) is to determine if the Oak Ridge (OR) Consolidated Edison Uranium Solidification Project (CEUSP) uranium-233 $\left({ }^{233} \mathrm{U}\right)$ waste stream (DRTK000000050, Revision 0) is acceptable for shallow land burial (SLB) at the Area 5 Radioactive Waste Management Site (RWMS) on the Nevada National Security Site (NNSS), formerly the Nevada Test Site (NTS). (All quotations featuring the name of the site have been updated from "NTS" to "NNSS.") The CEUSP ${ }^{233}$ U waste stream consists of 403 sealed stainless steel canisters partially filled with approximately 4.2 kilograms $(\mathrm{kg})$ of a ceramic-like uranium oxide $\left(\mathrm{U}_{3} \mathrm{O}_{8}\right)$ monolith (Isotek 2012a). The CEUSP ${ }^{233} \mathrm{U}$ waste stream requires a special analysis because the concentrations of thorium-229 $\left({ }^{229} \mathrm{Th}\right),{ }^{230} \mathrm{Th},{ }^{232} \mathrm{U},{ }^{233} \mathrm{U}$, and ${ }^{234} \mathrm{U}$ exceeded their NNSS Waste Acceptance Criteria action levels. The acceptability of the waste stream is evaluated by determining if performance assessment (PA) modeling provides a reasonable expectation that disposal by SLB is protective of human health and the environment.

\subsection{Special Analysis Background}

\subsubsection{Applicable Regulations}

Radioactive waste is managed based on how it is categorized by regulation. Some radioactive wastes are categorized based on their source, such as spent nuclear fuel (SNF), high-level radioactive waste (HLW), and uranium mill tailings. SNF is fuel that has been made highly radioactive by irradiation in a nuclear reactor. HLW is the highly radioactive liquid and solid wastes produced by reprocessing of SNF. Uranium mining and mill tailings are the tailings or waste produced by the extraction or concentration of uranium or thorium from naturally occurring ores.

Other radioactive wastes are categorized based on the waste's characteristics. Transuranic (TRU) waste is man-made, long-lived, alpha particle-emitting waste with concentrations greater than 100 nanocuries per gram ${ }^{-1}\left(\mathrm{nCi} \mathrm{g}^{-1}\right)$. The man-made TRU criterion is defined as heavy elements with atomic numbers greater than the heaviest naturally occurring element, uranium, which has an atomic number of 91 .

The disposal of radioactive waste generated by the U.S Department of Energy (DOE) is regulated under DOE Order DOE O 435.1 (DOE 2001), which invokes compliance with the requirements in DOE Manual DOE M 435.1-1 (DOE 1999a). Low-level radioactive waste (LLW) is defined in DOE M 435.1-1 by exclusion as radioactive waste not falling into the HLW, SNF, TRU, or the uranium mill tailings categories.

The CEUSP ${ }^{233} \mathrm{U}$ is not HLW or SNF because it is an unirradiated nuclear fuel. Although ${ }^{233} \mathrm{U}$ is a man-made, long-lived, alpha-emitting nuclide, it is an isotope of uranium with an atomic number of 91 . Therefore, it is not legally regulated as TRU waste. The CEUSP ${ }^{233} U$ is a man-made material not produced by uranium mining or milling. The CEUSP ${ }^{233} \mathrm{U}$ waste is LLW because it is not HLW, SNF, TRU, or uranium mining or mill tailings. 
LLW disposed by the DOE must be shown by PA to meet the performance objectives contained in DOE M 435.1-1. The performance objectives are applied to all radioactive waste disposed after the DOE O 435.1 implementation date of September 26, 1988. Compliance is assessed for a period of 1,000 years (y) after final closure.

\subsubsection{Special Characteristics of CEUSP ${ }^{233} \mathrm{U}$ Waste Stream}

The sources and characteristics of radioactive wastes are numerous and complex. Waste management regulations have limitations and may not appropriately categorize every new or unique waste (See for example U.S. Nuclear Regulatory Commission [NRC] 2009).

The LLW category was conceived as waste safe for disposal in the near-surface environment (NRC 1981) where near-surface is defined as in the upper 30 meters (m) (98 feet [ft]) of the land surface (Code of Federal Regulations [CFR] 2008; International Atomic Energy Agency 1999). Because LLW is defined by excluding a finite set of waste categories, it is possible that unique wastes not suitable for near-surface disposal may fall into the LLW category.

The CEUSP ${ }^{233} \mathrm{U}$ is an uncommon man-made material, rarely disposed in concentrated form as waste. It has special characteristics that pose a potential concern for near-surface disposal. Special characteristics of ${ }^{233} \mathrm{U}$ potentially affecting its long-term performance in the near-surface include the following:

- The long half-life of ${ }^{233} \mathrm{U}, 1.6 \times 10^{5} \mathrm{y}$, significantly exceeds the LLW 1,000-y compliance period contained in DOE M 435.1-1.

- $\quad{ }^{233} \mathrm{U}$ is a man-made, long-lived, alpha-emitting radionuclide with significant inhalation and ingestion dose conversion factors.

- $\quad{ }^{233} \mathrm{U}$ decays to a serial radioactive decay chain. The first radioactive progeny, ${ }^{229} \mathrm{Th}$, is a long-lived alpha emitter that has a large inhalation dose conversion factor when in secular equilibrium with its short-lived progeny.

- The ${ }^{233} \mathrm{U}$ production process unintentionally produces ${ }^{232} \mathrm{U}$ as a contaminant. ${ }^{232} \mathrm{U}$ is an alpha emitter with a 69 y half-life that decays to ${ }^{228} \mathrm{Th}$. ${ }^{228} \mathrm{Th}$ decays to a series of short-lived progeny that have significant external irradiation dose conversion factors. The progeny of ${ }^{232} \mathrm{U}$ in the CEUSP waste generate very high gamma exposure rates.

Although the CEUSP ${ }^{233} \mathrm{U}$ waste stream is LLW, the effect of the waste's long half-life and its unique radiological hazards should be considered in an evaluation of its acceptability for disposal in the near-surface as a LLW.

\subsubsection{Special Analysis Approach}

The SA uses a two tier approach to evaluate the acceptability of CEUSP ${ }^{233} \mathrm{U}$ waste stream for SLB at the Area 5 RWMS. The objective of the first tier is to provide reasonable expectation of compliance with the performance objectives in DOE M 435.1-1 for a period of 1,000 y. The objective of the second tier is to evaluate the long-term acceptability of the CEUSP ${ }^{233} \mathrm{U}$ waste for near-surface disposal at the Area 5 RWMS. Radioactive waste regulations for long-lived wastes address long-term risks by requiring an increased depth of burial, increasing the duration 
of the required risk assessment, and requiring site characteristics, engineered barriers, and administrative controls that provide additional assurance of long-term site stability. Therefore, the tier II evaluation considers factors that enhance site stability (e.g., site characteristics, engineered barriers, container integrity, and administrative controls), the long-term performance of the CEUSP ${ }^{233} \mathrm{U}$ waste, and the appropriate depth of burial.

The long half-life of ${ }^{233} \mathrm{U}$ indicates that risks may exist beyond the DOE LLW 1,000-y compliance period. The tier II analysis quantitatively evaluates the performance of the CEUSP ${ }^{233} \mathrm{U}$ waste to $10,000 \mathrm{y}$ and determines the timing and magnitude of the maximum dose from the CEUSP waste. A 10,000 y analysis period is selected for quantitative analysis because:

- Multiple model assumptions and conceptual models are reasonably likely to remain valid within $10,000 \mathrm{y}$.

- Other radioactive waste regulations addressing long-lived wastes use a quantitative 10,000-y compliance period (see NRC 1996; CFR 1994, 2001).

- $\quad$ The ${ }^{233} \mathrm{U}$ decay chain will reach $89 \%$ of its peak activity in $10,000 \mathrm{y}$.

The greater uncertainty of analyses conducted to the time of peak dose, well beyond 10,000 y, makes quantitative analysis impractical. Compliance with quantitative performance objectives cannot be assured with confidence for such long-term analyses due to the great uncertainties about the future state of the disposal system and surrounding geosphere. Increasing the assessment to 10,000 y requires re-evaluation of features, events, and processes (FEPs) for possible inclusion in the assessment.

Long-lived radioactive waste not suitable for near-surface disposal (e.g., HLW, SNL, and TRU) require disposal in a deep geologic repository. The advantages of a deep geologic repository are understood to include the following:

- Little need for active maintenance and inspection

- Less potential for disturbance by inadvertent human activity and near surface biotic processes (e.g., plant rooting, animal burrowing)

- No vulnerability to near-surface geologic processes

- Isolation from climatic variations and induced hydrologic variations

Waste regulations recognize that deep geologic disposal may not be necessary for all long-lived waste due to limited waste quantities, special site characteristics, or engineered barriers (see for example DOE M 435.1-1, Chapter II, Part B; 10 CFR Section 61.58; 40 CFR Section 191.04). The TRU waste disposed in the near-surface at the Area 5 RWMS, in $21 \mathrm{~m}$ (69 ft) deep Greater Confinement Disposal boreholes, has been shown to meet the requirements of 40 CFR Part 191 (Cochran et al. 2001). The intent of the tier II analyses is to determine if the disposal site's natural features, engineered barriers, administrative controls, and the waste characteristics are such that disposal in the near-surface is acceptable. 
This SA is organized into seven chapters, described briefly below:

- Chapter 1: Summarizes the purpose and approach of the SA.

- Chapter 2: Describes site conditions and the disposal site. Special emphasis is placed on site conditions, engineered barriers, and administrative controls that enhance long-term site stability and security. The OR CEUSP ${ }^{233} \mathrm{U}$ waste inventory, waste form, and containers are also discussed.

- Chapter 3: Summarizes the modeling methods used in the SA.

- Chapter 4: Presents the tier I results, showing reasonable expectation of compliance with DOE M 435.1-1 performance objectives for 1,000 y.

- Chapter 5: Presents the tier II modeling results, which describe the long-term performance of the CEUSP ${ }^{233} \mathrm{U}$ waste and the effects of the depth of burial and container integrity.

- Chapter 6: Summarizes the conclusions of the SA.

- Chapter 7: Lists references cited. 


\subsection{Site Description}

\subsection{Summary of Site Characteristics}

The Area 5 RWMS is located in Frenchman Flat on the NNSS approximately 105 kilometers (km) (65 miles [mi]) northwest of the Las Vegas metropolitan area, population 1.9 million (State of Nevada Demographer 2013). Outside of Las Vegas, the region is one of the least populous regions in the U.S. due to the lack of water resources. The ecologic and hydrogeologic conditions on the NNSS (DOE 1997; Shott et al. 1998; Ostler et al. 2000; Bechtel Nevada [BN] 2006a) and at the Area 5 RWMS (Reynolds Electrical and Engineering Company 1993, 1994; Istok et al. 1994; Blout et al. 1995) have been summarized previously. Frenchman Flat is a closed basin typical of the Basin and Range Province, filled with 360 to $460 \mathrm{~m}$ (1181 to $1509 \mathrm{ft}$ ) of alluvial sediments. Permanent surface waters do not occur within the basin. The uppermost aquifer is found in the alluvial sediments approximately $236 \mathrm{~m}(774 \mathrm{ft})$ below the Area 5 RWMS. Frenchman Flat receives an average of 12 centimeters $(\mathrm{cm})(4.7$ inches [in.]) of precipitation per year, and potential evapotranspiration is approximately $150 \mathrm{~cm} \mathrm{y}^{-1}\left(59\right.$ in $\left.\mathrm{y}^{-1}\right)$. The floral community surrounding the site is a creosote bush (Larrea tridentata) shrubland characteristic of the Mojave Desert. Aboveground net primary productivity is comparatively low ( $\sim 300$ kilograms per hectare per year $\left[\mathrm{kg} \mathrm{ha}^{-1} \mathrm{y}^{-1}\right]$ ), and plant roots are rare below the depth of infiltrating precipitation, which is approximately $2.5 \mathrm{~m}(8.2 \mathrm{ft})$.

Multiple results from site characterization studies indicate that precipitation does not infiltrate below the depth of the plant root zone and recharge of the aquifer is negligible under current climatic conditions. A large accumulation of chloride is observed at approximately $2.5 \mathrm{~m}$ (8.2 ft) in the alluvial sediments, indicating the depth of infiltrating precipitation. The amount of accumulated chloride indicates that recharge to the aquifer ceased 10,000 to 15,000 y ago (Tyler et al. 1996; Scanlon et al. 2003). Weighing lysimeters, in operation for $18 \mathrm{y}$, have not detected any drainage below a depth of $2 \mathrm{~m}(6.6 \mathrm{ft})$. Water potential measurements indicate that vadose zone pore water flows upwards in the upper $35 \mathrm{~m}$ (115 ft) of the vadose zone (Shott et al. 1998). Similar conclusions of negligible recharge have been made by others investigating arid intermountain valleys of the U.S. desert southwest (National Academy of Sciences 1995; Andraski 1997; Walvoord et al. 2002; Scanlon et al. 2003).

\subsection{Future Site Characteristics}

Increasing the duration of the risk assessment beyond 1,000 y requires consideration of long-term changes that might occur at the site. For a 10,000 y period, climate change is a key change that may drive other important changes in hydrology and the biotic communities present.

\subsubsection{Future Climate}

A previous SA evaluating TRU waste disposed in a SLB trench at the Area 5 RWMS considered climate change over 10,000 y (Shott et al. 2008). The previous SA adapted the Yucca Mountain Project (YMP) climate change forecast for use at the Area 5 RWMS. The YMP developed a model of future climate using a climate forecasting method based on the earth's orbital cycles (Forester et al. 1999; Bechtel Science Applications International Corporation [SAIC] 2004a). The climate forecast method attempts to establish the relationship between past climate states and periodic variations in the earth's orbital motion and to project these changes into the future. 
Using this approach, movement away from the present-day interglacial conditions is projected to begin in approximately 400 to 600 y (Bechtel SAIC 2004a) (Table 2.1). The present-day interglacial period is assumed to be followed by a monsoon period lasting 900 to 1,400 y. The remainder of the $10,000 \mathrm{y}$ period is expected to be a glacial-transition period.

Table 2.1 Summary of future climate states and their present-day analog sites as forecasted by the YMP (Bechtel SAIC 2004a)

\begin{tabular}{|c|c|c|}
\hline Climate State & Duration & Analog Site \\
\hline Inter-Glacial & $400-600 \mathrm{y}$ & Current Site Conditions \\
\hline Monsoon & $900-1,400 \mathrm{y}$ & $\begin{array}{r}\text { Upper Limit: Sonoran/Chihuahuan Desert } \\
\text { (e.g., Nogales, AZ, Hobbs, NM) } \\
\text { Lower Limit: Current Site Conditions }\end{array}$ \\
\hline Glacial & $\begin{array}{c}\text { Remainder of } \\
\text { Transition }\end{array}$ & $\begin{array}{c}\text { Upper Limit: Eastern Slope of the Cascade Mountains } \\
\text { (e.g., Spokane, Rosalia, and St. John, WA) } \\
\text { Lower Limit: Great Basin Desert } \\
\text { (e.g., Beowawe, NV, Delta, UT) }\end{array}$ \\
\hline
\end{tabular}

During the monsoon period, the subtropical high is assumed to move northward, producing a warmer climate with a wetter summer monsoon season, similar to conditions currently observed in the Sonoran and Chihuahuan deserts of southern Arizona and New Mexico. The glacial-transition period is expected to be wetter and colder than present-day conditions. Three sites on the eastern slope of the Cascade Mountains were selected as upper limit analog sites for the glacial transition period. These sites are under greater influence of the polar front and in the rain shadow of the Cascades. The lower limit conditions for the glacial-transition period are based on Great Basin Desert sites.

\section{Meteorological Conditions}

Site meteorological conditions are inputs to infiltration process models used to evaluate potential changes to the hydrogeologic conceptual model under climate change and to estimate soil moisture contents. Meteorological conditions also guide selection of parameters describing future flora and fauna. The meteorological conditions at Frenchman Flat during future climate regimes were estimated by scaling present-day conditions using the relative changes predicted for Yucca Mountain. Relative changes were estimated by comparing analog sites with current Yucca Mountain conditions (Table 2.2).

Table 2.2 Mean annual precipitation and temperature for current and future climate conditions as assumed by the YMP (Bechtel SAIC 2004b)

\begin{tabular}{|c|c|c|c|}
\hline Climate State & Location & $\begin{array}{c}\text { Mean Annual } \\
\text { Precipitation } \\
(\mathbf{m m})\end{array}$ & $\begin{array}{c}\text { Mean Annual } \\
\text { Temperature, } \\
\text { Celsius }\left({ }^{\circ} \mathbf{C}\right)\end{array}$ \\
\hline Current inter-glacial mean & Yucca Mountain Region & 188.5 & 15.1 \\
\hline Current inter-glacial upper limit & Yucca Mountain Region & 265.5 & 18.2 \\
\hline Monsoon mean & Nogales, AZ; Hobbs, NM & 300.5 & 17.2 \\
\hline Monsoon upper limit & Nogales, AZ; Hobbs, NM & 412.5 & 17.3 \\
\hline Glacial-transition mean & Rosalia, Spokane, St. John, WA & 316.1 & 9.8 \\
\hline Glacial-transition upper limit & Rosalia, Spokane, St. John, WA & 431.1 & 10.2 \\
\hline
\end{tabular}


The relative changes are used to scale the present-day Frenchmen Flat conditions to future conditions (Table 2.3).

Table 2.3 Mean annual precipitation and temperature for current and future climate regimes for Frenchman Flat

\begin{tabular}{|c|c|c|c|c|}
\hline \multirow{2}{*}{ Climate State } & \multicolumn{2}{|c|}{ Relative Change } & \multirow{2}{*}{$\begin{array}{l}\text { Estimated Frenchman } \\
\text { Flat Mean Annual } \\
\text { Precipitation (mm) }\end{array}$} & \multirow{2}{*}{$\begin{array}{l}\text { Estimated Frenchman } \\
\text { Flat Mean Annual } \\
\text { Temperature, }{ }^{\circ} \mathrm{C}\end{array}$} \\
\hline & Precipitation & Temperature & & \\
\hline Present-day & $1 X$ & \pm 0 & $\mathrm{~N}\left(123.82,8.11^{2}\right)^{\dagger}$ & $\mathrm{N}\left(15.2,0.04^{2}\right)$ \\
\hline Monsoon & $1.59 x$ & +0.6 & $N\left(197,32^{2}\right)$ & $N\left(15.8,0.04^{2}\right)$ \\
\hline Glacial-transition & $1.68 \mathrm{X}$ & -5.3 & $\mathrm{~N}\left(208,32^{2}\right)$ & $\mathrm{N}\left(9.9,0.17^{2}\right)$ \\
\hline
\end{tabular}

${ }^{\dagger}-\mathrm{N}(\cdot, \cdot)=$ Normal distribution(mean, variance)

\subsubsection{Future Hydrologic Conditions}

Future hydrologic conditions are estimated from the results of hydrologic process models using the climatic conditions described above and site specific soil properties. Monsoon climate regime analog sites do not appear to currently have infiltration below the plant root zone (Scanlon et al. 1999). The Hanford Site, an analog site for the glacial-transition period, has been reported to have low recharge rates ranging from 0.2 to 5 millimeters per y $\left(\mathrm{mm} \mathrm{yr}^{-1}\right.$ ) (Mann et al. 2003).

Hydrologic process model simulations of the vadose zone performed for the previous SA suggested that higher vadose zone water contents may occur with onset of a glacial-transition climate and that small downward water fluxes below the plant root zone may be initiated (Shott et al. 2008). The downward fluxes were not sufficient to recharge the uppermost aquifer within $10,000 \mathrm{y}$. It was concluded that climate change was not sufficient to initiate a groundwater pathway within $10,000 \mathrm{y}$.

\subsubsection{Future Ecology}

\section{Floral Community}

The climate changes described above were assumed to impact the floral community in the following areas:

- Plant community or species composition of plant associations

- Aboveground net primary productivity of plants

- Allometric structure of plants (i.e., root-to-shoot ratio, rooting depth, root depth distribution)

Primary productivity is the rate of production of plant biomass by the process of photosynthesis. Model plant-soil concentration ratios are generic and are assumed to be unaffected by climate change or changing plant communities. Climate change and ecosystem response are assumed to be instantaneous.

Under the monsoonal climate regime, Larrea tridentata is expected to remain as the dominant species surrounding the Area 5 RWMS based on analog sites. The plant community during the 
monsoonal period is assumed to have the same species compositions as present-day communities with increased primary productivity due to increased water availability.

The plant community assumed for the glacial-transition climate regime is based on present-day communities observed at analog sites with similar climatic and soil conditions. Low elevation areas at analog sites typically support shrub-steppe communities with big sagebrush (Artemisia tridentata) as the dominant species or in the past supported the now rare Palouse Prairie, a bunchgrass community dominated by bluebunch wheat grass (Agropyron spicatum) and Idaho fescue (Festuca idahoensis). Lower limit analog sites are Great Basin Desert sites.

The changes in plant communities described above were used to select revised inputs for primary productivity, plant rooting depth, and root distribution with depth. A complete description of the revised distributions can be found in Shott et al. (2008).

\subsubsection{Summary of Future Conditions}

Climate change is likely to change site conditions over the next 10,000 y. The changes described above were previously implemented for an SA of the TRU waste in Trench T04 (Shott et al. 2008). The results of this model indicate that climate change had minimal impacts on the maximum dose received by a resident. The inclusion of climate change reduced the resident dose by $2 \%$ at $10,000 \mathrm{y}$. A $2 \%$ change is not considered significant because (1) the change was a decrease rather than an increase; (2) a $2 \%$ change is small relative to result uncertainty, which is usually greater than $\pm 25 \%$; (3) a $2 \%$ change is not large enough to change any SA conclusion given that most results are $1 \%$ or less of their performance objective. Therefore, this SA does not use the Shott et al. (2008) climate change model based on the previous results, which showed that climate change effects were minimal and tended to reduce dose.

\subsection{Facility Features}

The Area 5 RWMS has multiple natural, engineered, and administrative features that enhance long-term site stability and security. Many of these features are not included in the PA model. They provide additional protection beyond model estimates of performance.

\subsubsection{Active Institutional Controls}

Active institutional controls (ICs) at the Area 5 RWMS include access controls, site maintenance, remedial actions, control and cleanup of releases, and monitoring. The NNSS's national security mission, legacy of aboveground and below-ground nuclear testing, and waste disposal operations require site access controls. Access controls are currently in place at the NNSS. Federal ownership of NNSS lands and numerous commitments in DOE land-use planning and policy documents ensure that access controls will continue indefinitely. Closure planning documents for the Area 5 RWMS include provisions for inspections and maintenance of passive ICs, the closure cover, and the environmental monitoring system. Closure plans also include provisions for detecting and responding to releases. 


\section{Access Control and Site Security}

Located in a remote and sparsely populated region, the NNSS is an ideal location for sensitive or hazardous national security activities. The U.S. government has committed to the oversight and management of the NNSS into the foreseeable future for the purposes of national security. The NNSS Environmental Impact Statement (EIS) (U.S. Department of Energy, Nevada Operations Office [DOE/NV] 1996) and Resource Management Plan (DOE/NV 1998a) state a primary mission of the NNSS is to "preserve the capability to resume underground nuclear testing ... and accomplish stockpile stewardship and national security missions.” Therefore, it is expected that public access will be restricted as long as the NNSS is an operational Defense Program facility.

Current access controls and site security features are summarized in the following passage from the Resource Management Plan (DOE/NV 1998a):

NNSS is surrounded by government-controlled buffer zones and protected by Security Police officers, mobile patrols, and highly trained emergency response teams. Sensitive areas within NNSS use chain-link fencing, protective alarms, closed-circuit television, and secure communications systems. The Nye County Sheriff's Department provides civil law enforcement.

NNSS is a controlled-access area with road access beginning at the Security Station on Mercury Highway, 5 miles (mi) from the U.S. Highway 95 Mercury turnoff. Although a security clearance is not required for entry, access is not allowed without proper identification and an identification badge. Personnel are issued dosimetry badges if entering areas where they might be exposed to radiation levels above background. Security areas within NNSS have stringent personnel controls, requiring the appropriate security clearance and an operational need before access is allowed.

The entire perimeter of NNSS is not fenced, but it is posted as a restricted area; access is prohibited except at designated entrances. Beyond the perimeter, the Bureau of Land Management (BLM) and NAFR (Nellis Air Force Range) (now NTTR [Nellis Test and Training Range]) provide buffer zones. Barricades and/or Security Stations control the few roads that access NNSS boundaries. Perimeter barricades are checked by security force patrols (DOE/NV 1998a, page 8-2).

As long as the NNSS national security mission continues, access controls will ensure that the public does not have access to the Area 5 RWMS.

\section{Post-Closure Inspections and Maintenance}

Post-closure inspection and maintenance activities for the Area 5 RWMS are outlined in the Area 5 RWMS Closure Plan (National Security Technologies, LLC [NSTec] 2008). The final inspection and maintenance strategy will be presented in the post-closure care plans for the Area 5 RWMS. The 92-acre Low-Level Mixed Waste Management Unit inspection and maintenance 
plan is compliant with Resource Conservation and Recovery Act (RCRA) requirements due to the presence of the Pit 3 Mixed Waste Disposal Unit.

The operational inspection program has requirements for environmental monitoring equipment, fire protection systems, safety and emergency equipment, security devices, and operating or structural equipment that are critical to prevent, detect, or respond to human health or environmental hazards. Records will be used by RWMS personnel to ensure inspections are conducted according to established schedules.

Post-closure inspection and maintenance will be minimized to the extent possible by the design of the disposal unit and closure cover system, and the additional site security measures.

Post-closure inspections will include the following:

- General facility inspection

- Boundary monument inspection

- Subsidence marker inspection and surveys

- Warning sign inspection

- Cover inspection

- Run-on/runoff inspection

During each inspection, any changes in the condition of the closure cover, vegetation, or fenced area will be documented (40 CFR Part 265.310(b)(1)). Specific changes noted on the current condition of the cover include, but are not limited to, trash and debris within the fenced compound, animal burrows or nesting activity, and erosion of the cover.

Maintenance activities will be based on inspection results. Custodial maintenance or repair actions may include repair of fences, replacement of warning signs, re-establishment of location control monuments, removal of unwanted vegetation, and reconstruction of slopes, cover, or embankments.

All repair work to the cover will ensure that the integrity of the cover and design is maintained “as built.” For RCRA-regulated disposal units, if cover repair requires modifications of the closure cover design, the U.S. Department of Energy, National Nuclear Security Administration Nevada Site Office (NNSA/NSO) will present a formal design modification request to the Nevada Division of Environmental Protection (NDEP) prior to making the design modification.

Closure and post-closure monitoring documentation will be maintained in the Area 5 RWMS files and at the NNSA/NSO Public Reading Room in North Las Vegas. The files will be available for public inspection and review upon request.

\section{Emergency Response}

Except for extraordinary events, the site access restrictions, closure cover design, post-closure inspections and preventive maintenance are expected to mitigate the need for emergency release response during the active control period. NNSS environmental surveillance and site-specific monitoring programs are designed to detect conditions that indicate a potential containment 
breach. After detection, further investigation may be necessary to confirm site conditions and to assess the scope and nature of the problem. The type and level of response will depend on the scope and nature of the problem and the hazards that must be addressed to implement the response safely. The response may include several phases of activity including quick containment measures and longer-term construction projects. The NNSS has onsite capacity to address many types of emergencies rapidly and is likely to maintain such capacity while active U.S. Department of Defense (DoD) and DOE operations remain.

\subsubsection{Passive Institutional Controls}

Passive ICs include markers, public records and archives, government ownership, and land- and resource-use policies. Land-use policies for the NNSS reflect the need to control residual radioactive contamination from past activities. Inactive facilities and areas known to be contaminated and require access controls are fenced and posted with warning signs. In remote areas where personnel rarely work, appropriate posting at the perimeter boundary as well as access roads to the contaminated area may be substituted for fencing. Further program enhancement is accomplished by following the Integrated Safety Management guiding principles and core functions (DOE/NV 1998a, page 9-8).

\section{Markers, Signs, and Fencing}

Area 5 RWMS disposal units are marked by concrete boundary markers at their four corners. Although these markers may be buried during final site closure, intruders may still detect their presence and be alerted to the potentially hazardous nature of the site.

Fencing with warning signs every $30 \mathrm{~m}$ (100 ft) will be installed around the Area 5 RWMS. Regulated units within the Area 5 RWMS that have specific posting requirements include Federal Facility Agreement and Consent Order (FFACO)-regulated units (Corrective Action Unit [CAU] 111), Toxic Substance Control Act-regulated asbestiform disposal units, and LLW disposal units that must be posted as buried radioactive materials areas. These controls will indicate the presence and hazardous nature of the site after the end of active ICs.

\section{Land Ownership and Land Use}

The NNSS occupies federally owned public lands that are administered by the U.S. Department of the Interior and BLM. Most of the land surrounding the NNSS is also owned and controlled by various agencies of the federal government (Figure 2.1). 


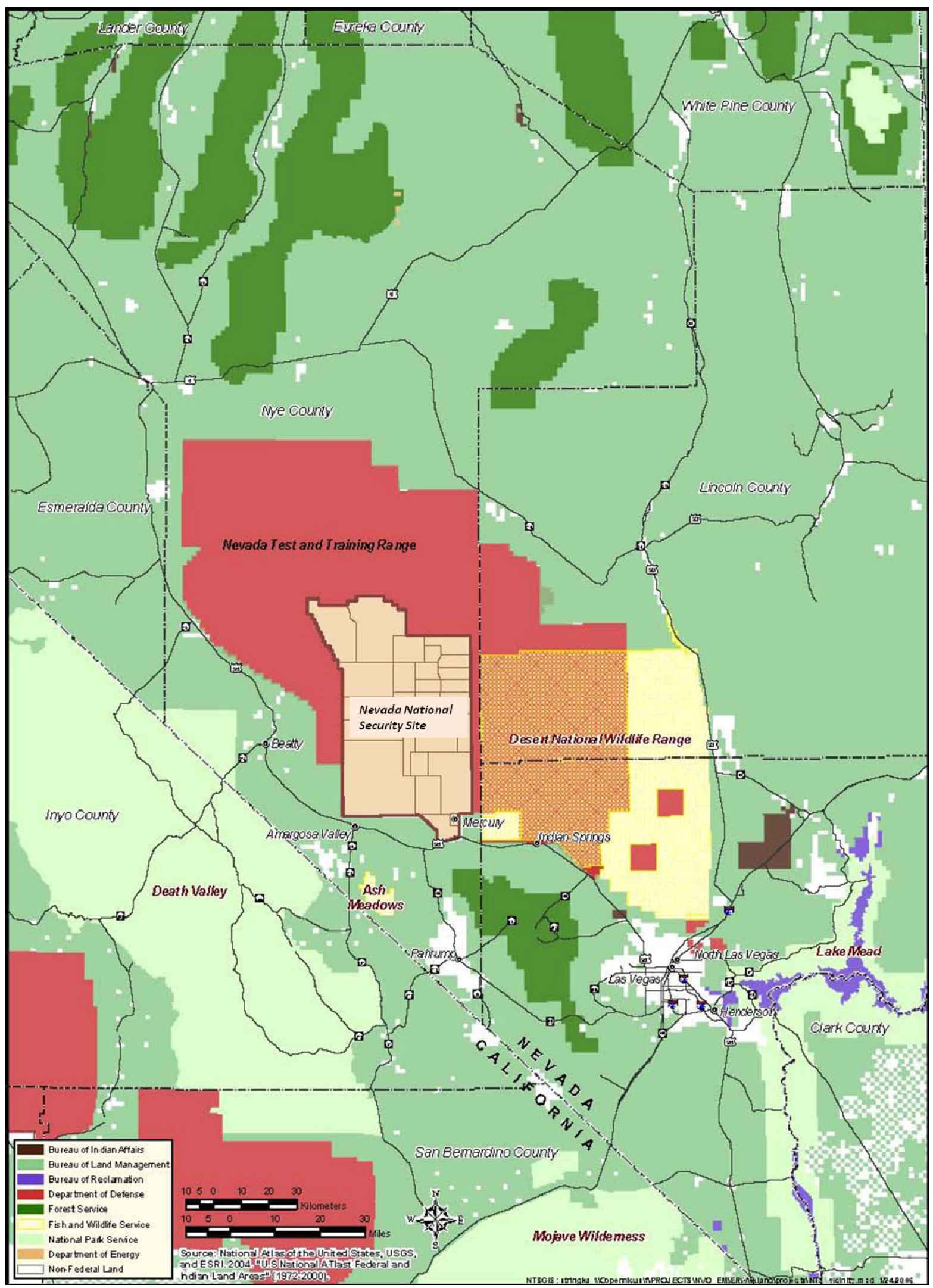

Figure 2.1 Ownership of lands surrounding the NNSS 
DOE has jurisdiction of the NNSS through withdrawals under public land laws, including mining and mineral leasing laws through the public land orders, and a memorandum of understanding (NNSA/NSO 2006). As part of closing the 1997 Settlement Agreement, the 740 acres that make up the Area 5 RWMS were removed from the U.S. Department of the Interior land withdrawal and transferred custody and accountability to NNSA/NSO. This action strengthens DOE's ability to ensure that undisturbed burial is designated and will be sustained indefinitely for the Area 5 RWMS.

In July 2011, the RWMS was included in the Underground Test Area (UGTA) Corrective Action Decision Document/Corrective Action Plan for Corrective Action Unit 98: Frenchman Flat Nevada National Security Site, Nevada (NNSA/NSO 2011), which identifies planned use restriction (UR) boundaries. The planned URs will be finalized and recorded in the DOE Facility Information Management System, the FFACO database, the DOE CAU/Corrective Action Site files, UGTA Closure Report for Frenchman Flat CAU, and the U.S. Air Force Geographic Information Systems. The planned UR boundaries surround the 1,000-y forecasted groundwater contaminant boundaries and the Area 5 RWMS.

Closure of the NNSS and/or transfer of responsibility to another organization was not considered in the NNSA Complex Transformation Special Programmatic EIS (SPEIS) (DOE 2008) or December 2008 Record of Decision. The Complex Transformation SPEIS addressed consolidating Nuclear Weapons Complex facilities and activities. There are no plans to relinquish any additional land currently under their responsibility according to the 2006 Nevada Test Site Environmental Management End State Vision (NNSA/NSO 2006). The NNSS remains federally owned, access-controlled, and withdrawn from public settlement, location, or entry.

\section{Public Records}

NNSA/NSO has entered into the FFACO with the DoD and the State of Nevada (FFACO 1996, as amended). This agreement specifies a process for the identification, remediation, and closure of CAUs on the NNSS. The FFACO-planned URs for CAUs near the Area 5 RWMS are part of the active IC strategy for the Area 5 RWMS. Anticipated FFACO-planned URs in Frenchman Flat have implications for future public access for drilling water wells and for the likelihood of human intrusion at the site.

The Area 5 RWMS is within the Frenchman Flat CAU, one of five CAUs on the NNSS assigned to the NNSA/NSO UGTA Activity. The corrective action for the UGTA CAUs is closure in place with modeling, monitoring, and ICs (FFACO 1996, as amended). The corrective action strategy for UGTA relies on model forecasted contaminant boundaries for each CAU that encompass areas that potentially exceed the radiological requirements of the Safe Drinking Water Act (CFR 2012). Initial UR boundaries, based partly on the contaminant boundary forecasts, have been established and will be finalized once the CAU progresses to the closure report (CR) stage. During the CR stage, final UR boundaries are established, a long-term closure monitoring program is developed and implemented, and the approaches and policies for ICs are established and implemented. 
The expectation for UGTA management is that protection of human health and the environmental will be based on controlled access to areas of potential contamination (areas within the planned UR boundary). As part of the FFACO process, land UR forms and maps are approved by NDEP and become official records for documenting sites with remaining contamination after closure. NNSA/NSO, BLM, and the U.S. Air Force will maintain use restriction records as long as the land is under their jurisdiction.

The Area 5 RMWS is within the initial UR boundary for the Frenchman Flat CAU (CAU 98). The planned URs will prohibit public access to contaminated groundwater for 1,000 y. Planned land URs will ensure that the member of public is farther than at the $100 \mathrm{~m}(330 \mathrm{ft})$ site boundary and will reduce the likelihood of releases caused by inadvertent intrusion.

Public records will be recorded as part of final closure of the site and compliance with the FFACO. Final closure of the Area 5 RMWS under the FFACO requires that a survey plat of the site including the location and dimensions of all disposal units be submitted to NDEP. Planned land URs for the site will also be recorded in the FFACO and the NNSS Information Management Systems databases.

\section{Federal Land-Use and Long-Term Stewardship Policies}

Numerous government policies for NNSS land-use and long-term stewardship written to manage resources and provide protection from residual radioactive contamination provide another assurance of continuing IC. The NNSS EIS (DOE/NV 1996) defined NNSS land uses for planning purposes. The Area 5 RWMS is designated as a "Waste Management Site" and is managed through a comprehensive waste management program in accordance with pertinent DOE orders, policies, and federal regulations. Closure requirements are designed to help protect future users of the property from exposure to the contaminants in waste.

The NNSS Resource Management Plan indicates that the Area 5 RWMS is within a Restricted Use Zone (DOE/NV 1998a). Activities within a Restricted Use Zone must, among other criteria, be "compatible with NNSS natural and manmade resources." Additionally, there must be a "compelling need (such as security, restricted access, remote location, physical characteristics) that drives the project to be located within the security boundary of NNSS."

Processes and permits that ensure land-use plans are enforced during the period of active IC include the following:

- $\quad$ FFACO planned URs for the Frenchman Flat CAU (CAU 98) and the Area 5 RWMS SLB Trenches (CAU 111)

- NNSS excavation permits

- NNSS radiological work permits

- State of Nevada groundwater well permits

- National Environmental Protection Act checklist reviews and compliance for planned NNSS activities 
The U.S. government's commitment to the long-term environmental stewardship of the NNSS while accomplishing agency missions has been stated in multiple planning and policy documents including the following:

- DOE Policy DOE P 430.1, “Land and Facility Use Planning” (DOE 1996)

- Accelerating Cleanup: Paths to Closure (DOE 1998)

- Accelerating Cleanup: Paths to Closure (DOE/NV 1998b)

- From Cleanup to Stewardship (DOE 1999b)

- NNSS Resource Management Plan (DOE/NV 1998a)

- Performance Management Plan (NNSA/NSO 2002)

- U.S. Department of Energy, Nevada Test Site, Environmental Management, End State Vision (NNSA/NSO 2006)

- Institutional Control of the Nevada Test Site (NNSA/NSO 2008)

The DOE's policy is to manage its "land and facilities as valuable natural resources, with stewardship based on principles of ecosystem management and sustainable development. ... The goal of NNSS ecosystem management is to accomplish the DOE/NV missions of national security, EM (Environmental Management), technology diversification, energy efficiency and renewable energy, and NNSS stewardship while at the same time, sustaining the health and biological diversity of NNSS ecosystems" (DOE/NV 1998b, page 4-1). Furthermore, "DOE will maintain a presence at NNSS to ensure reduced risks to human health and the environment. This long-term stewardship will include passive and active ICs, the degree of which will be determined through negotiations between DOE/NV, regulators, Tribal Nations, and stakeholders” (DOE/NV 1998b).

The NNSA/NSO and DOE contractors at the NNSS must comply with DOE O 450.1, "Environmental Protection Program" (DOE 2003a). The principal objective of DOE O 450.1 is "to implement sound stewardship practices that are protective of the air, water, land, and other natural and cultural resources impacted by DOE Operations and by which DOE cost effectively meets or exceeds compliance with applicable environmental; public health; and resource protection laws, regulations and DOE requirements” (DOE 2003a).

The NNSA/NSO Performance Management Plan (U.S. Department of Energy, Nevada Operations Office [NNSA/NV] 2002) is compliant with DOE Policy DOE P 455.1, "Use of Risk-Based End States” (DOE 2003b). Expected future land uses are a driver in selecting acceptable end state conditions and cleanup goals for the NNSS. NNSA/NSO EM's land management assumptions and framework for Environmental Management activities include:

The NNSS will remain under federal control in perpetuity as an NNSA test site, and the large buffer zone surrounding the NNSS (the Nevada Test and Training Range) is assumed to remain under the control of the U.S. Air Force. There are no plans for transfer of any NNSS lands to other agencies or public entities. Access will continue to be restricted to the NNSS and the surrounding areas. 
For management purposes, NNSA/NV EM activities have been established based on the source of contamination and type of waste requiring management. Environmental Restoration activities within the state of Nevada fall under the purview of a formal regulatory agreement, the Federal Facility Agreement and Consent Order (FFACO). . . . Waste Management activities are governed by the Federal Facility Compliance Act and Consent Order (FFCAct) and the Mutual Consent Agreement (MCA). A Joint Low-Level Waste Oversight Agreement is in place to allow State of Nevada representatives to participate in review and approval processes associated with waste receipt and disposal operations (NNSA/NV 2002, page 5).

The DOE EM End State Vision for NNSS (NNSA/NSO 2006) addresses contaminated sites controlled by NNSA/NSO EM. "The long-term end state vision of the NNSS is to restore the environment to an extent that will allow the maximum continuation of the National security mission conducted by the NNSA/NSO, the national laboratories and contractors" (NNSA/NSO 2006, page ES-1).

DOE criteria for free release of land may result in an extended federal environmental stewardship role. Because of past activities, including both atmospheric and underground nuclear weapon tests, some land within the NNSS boundary cannot be released for unrestricted use without remediation. It is not cost-effective to remediate residual contamination from underground nuclear testing, and long-term land-use restrictions will be required (DOE/NV 1997).

NNSA/NSO has programs to ensure compliance with DOE O 458.1 to limit annual exposure of the public to 0.1 millisievert (mSv) in a y (DOE 2011). DOE O 458.1 also contains conditions and requirements for unrestricted release of land. Because some residual contamination from past nuclear tests is likely to be closed in place, and will persist for many years, portions of NNSS (e.g., Yucca Flat and Frenchman Flat) may not meet unrestricted release requirements. Therefore, URs will preclude new rural development, mining permits, groundwater wells, and other intrusive uses, even after DoD and DOE activities cease.

DOE/NV (1998b) projects long-term federal stewardship: "Institutional control of the NNSS is assumed in perpetuity at the existing boundaries." If DOE ceases to exist, it is assumed that "another federal agency will become the landlord . . . as IC of the site is considered an obligation of the federal government and one that is expected to be maintained."

\section{Control Effectiveness}

Convening a panel of independent subject matter experts (SMEs) (Black et al. 2001), NNSA/NSO evaluated the effectiveness and probable duration of long-term ICs in Frenchman Flat. The SMEs unanimously agreed that a combination of active and passive ICs would not last for 10,000 y (the elicitation's target compliance period) because no human institution, government, or political civilization has lasted for this length of time. Instead the SMEs focused on the time frame in which IC might be lost. The consensus opinion was that IC would be lost within 1,000 y (90\% probability), that IC has a reasonable chance of lasting about 250 y (50\% 
chance), and that it was very likely to last at least 50 y ( $90 \%$ chance). The SMEs also suggested that 2,000 $\mathrm{y}$ is the longest period of time for which IC could reasonably be expected to last. The SMEs considered a time frame of 100 to $500 \mathrm{y}$ for IC because they expected that it would take this long for sociopolitical will to erode sufficiently for IC to cease.

\subsubsection{Monitoring}

An integrated closure and monitoring plan has been developed for the Area 5 RWMS (NSTec 2008). The Area 5 RWMS monitoring system consists of a combination of direct monitoring of radionuclides released from the disposal system as well as monitoring transport mechanisms, which could lead to the release of radionuclides to the accessible environment. The monitoring system consists of the following elements:

- Vadose Zone Monitoring

- Groundwater Detection Monitoring

- Radon Monitoring

- Meteorology Monitoring

- Biota Monitoring

- Subsidence Monitoring

- Air Monitoring

\section{Vadose Zone Monitoring}

Vadose zone monitoring is conducted to confirm the key assumption of no downward pathway, to detect changes in system performance, and to establish baseline data for long-term monitoring. The vadose monitoring system consists of weighing lysimeters and instrumented operational covers. Two precision weighing lysimeters have been in continuous operation since March 1994. One lysimeter is vegetated with native plant species at the approximate density of the surrounding desert, and the other lysimeter is kept bare to simulate operational covers. The lysimeters are capable of measuring changes in storage of \pm 800 grams or $\pm 0.1 \mathrm{~mm}$ of water. Additionally, both lysimeter soil columns are instrumented with time domain reflectometers for volumetric water content and heat dissipation probes for matric potential and soil temperature measurements.

Three operational covers and one pit floor are instrumented with time domain reflectometers. Sensors are installed throughout the cover profile to a depth of $1.80 \mathrm{~m}(6 \mathrm{ft})$. Heat dissipation probe arrays are also installed in two of the operational covers. Vadose zone sensors are typically read once a day.

\section{Groundwater Monitoring}

Groundwater monitoring has been conducted for a suite of radiologic and chemical constituents at the three wells surrounding the Area 5 RWMS since 1993. The wells have been sampled semi-annually for RCRA compliance and biennially as part of the site-wide groundwater monitoring program. Water table elevation measurements taken at the three wells surrounding the RWMS, as well as neighboring wells, indicate the uppermost aquifer is approximately $236 \mathrm{~m}$ 
(775 ft) below ground surface and is essentially flat, with little to no appreciable groundwater flow.

\section{Meteorology Monitoring}

Detailed meteorological data are collected at the Area 5 RWMS. Measurements include precipitation, air temperature, relative humidity, wind speed and direction, barometric pressure, and incoming solar radiation. Hourly data are recorded. These basic meteorological parameters are required to quantify the exchange of water and heat between the soil and atmosphere. Meteorological measurements are taken to (1) confirm the RWMS is sited in an arid environment, (2) be used as input for process level models, and (3) refine PA parameter distributions.

\section{Subsidence Monitoring}

Subsidence has been formally monitored since 2000. Subsidence occurs most commonly in recently filled disposal units, especially between the trench wall and the waste stack where soil backfill may not be completely compacted. Subsidence monitoring ensures subsidence features are repaired to maintain the integrity of the closure cover.

\section{Air Monitoring}

Air particulate samples are collected weekly at two stations surrounding the Area 5 RWMS using glass fiber filters. Air particulate samples are screened for gross alpha and gross beta activity weekly. Monthly composites are analyzed by gamma spectrometry for gamma-emitting radionuclides and by radiochemical analyses for americium and plutonium.

Atmospheric moisture is collected and analyzed for tritium $\left({ }^{3} \mathrm{H}\right)$ at two stations. Tritium samples are collected over a 2-week period. Tritium acts as a conservative tracer and therefore is an excellent indicator of volatile radionuclide migration from waste cells.

\section{Biota Monitoring}

Vegetation growing on and around waste disposal units is periodically sampled. Vegetation sampling provides a direct measure of radionuclide transport through plant uptake. Due to its high mobility, ${ }^{3} \mathrm{H}$ is the primary target analyte, although other radionuclides are often included in the analysis suite. Small burrowing animals also are collected periodically and analyzed for radionuclides.

\section{Radon Flux Density}

Radon-222 $\left({ }^{222} \mathrm{Rn}\right)$ flux density measurements are taken at locations within the Area 5 RWMS, which have the highest expected present-day fluxes, to provide supporting data for volatile radionuclide transport calculations. 


\section{Post-Closure Monitoring}

Monitoring data will be evaluated and compared on an annual basis against PA model assumptions to confirm conceptual and parameter assumptions are not changing. Included in these evaluations will be recommendations for changes in frequency or addition/deletion of monitored parameters.

\subsubsection{Natural and Engineered Barriers}

\section{Natural Barriers}

Barriers are defined as any material or structure that prevents or substantially delays movement of water or radionuclides toward the accessible environment. Previous PAs have identified multiple natural barriers at the Area 5 RWMS including:

- The thick dry vadose zone below the site. The extremely low hydraulic conductivity of the dry alluvium (approximately $1 \times 10^{-10} \mathrm{~cm}$ per second) and thickness of the vadose zone (236-272 m [774-892 ft]) leads to extremely long travel times. The median travel time for water under current conditions has been estimated to be 51,000 y (Shott et al. 1998).

- The thick homogenous alluvium below the site. Contaminants must migrate through a tortuous porous medium rather than through rapidly flowing fractures in rock.

- The nearly flat groundwater table below the site. If any contaminants were to reach the saturated zone, lateral migration to the edge of the controlled area would be extremely slow because of the negligible gradient.

- The extremely dry cover soil conditions. Mean cover volumetric water contents range from 0.058 to 0.079 . The low water contents are maintained by high evapotranspiration and low precipitation.

- The alkaline soil conditions that retard the migration and reduce the solubility of most cationic metals.

- Remote location of the site relative to population centers. The great distance to population centers allows greater dispersion and dilution of contaminants in groundwater and air before reaching receptors.

- The site's location in a closed basin surrounded by mountain ridges. Airborne particulates dispersed from the site will impinge and be deposited on higher elevation terrain surrounding the site before reaching population centers.

- The adaptations of native plants to xeric conditions. Native Mojave Desert plants are able to efficiently withdraw water from cover soil, maintaining low hydraulic conductivities and extremely negative soil matric potentials in the plant root zone.

- The low primary productivity of native plants. The present-day Mojave Desert assemblage has an annual net primary productivity of only approximately $300 \mathrm{~kg} \mathrm{ha}^{-1} \mathrm{yr}^{-1}$. 
- The shallow rooting depth of native plants. Native plants roots seldom penetrate below the dynamic range of infiltrating precipitation, 2 to $3 \mathrm{~m}(6.5$ to $9.8 \mathrm{ft})$.

- The shallow burrowing depth of rodents, the most abundant burrowing animals.

\section{Engineered Barriers}

Engineered barriers are materials or structures intentionally placed at the site to increase the isolation of the waste from the accessible environment. Engineered barriers already present include the waste containers and the $2.4 \mathrm{~m}(8 \mathrm{ft})$ operational closure cover.

Previous PAs have identified a number of alternative barriers that might be expected to provide additional assurance that the requirements can be met (Black et al. 2001; NSTec 2007). Because all release and transport pathways are upward, barriers that deter human intrusion and block biointrusion, upward liquid advection/diffusion, and gaseous diffusion are obvious choices. Barriers can be categorized as subsurface resistive barriers that resist biointrusion and slow upward advection/diffusion, subsurface intrusion barriers, and surface intrusion barriers.

The main engineered feature of the facility is the closure cover, currently planned to be a $2.5 \mathrm{~m}$ $(8.2 \mathrm{ft})$ thick vegetated monolayer-evapotranspirative (ET) type cover constructed from native alluvium (NSTec 2008). The Area 5 RWMS will be closed in phases. The 92-acre Mixed Waste Management Unit was closed in fiscal year (FY) 2011 with a 2.5 m (8.2 ft) thick vegetated monolayer-ET type cover constructed from native alluvium.

Although an engineered feature, the closure cover design is designed to rely on natural site conditions to isolate waste. The most important transport pathways are expected to be upward pathways to the land surface because of the near-surface disposal of waste and absence of a groundwater pathway. The cover design relies on the cover thickness and natural site conditions to isolate waste constituents.

The monolayer-ET cover will reestablish the natural desert conditions that have controlled and eliminated recharge at the site for at least the last 10,000 y. Under natural conditions, rainfall on Mojave Desert valleys infiltrates at most a few meters into the ground and then is evapotranspired back to the atmosphere. Recharge occurs along the edges of mountain ranges and in drainage channels near mountain fronts. The chloride accumulation observed below the root zone supports the conclusion that recharge ceased in these areas at the end of the last pluvial period, approximately 10,000 to 15,000 y ago. A $2.5 \mathrm{~m}(8.2 \mathrm{ft})$ vegetated cover will effectively isolate waste from infiltrating precipitation. Transpiration by desert plants is believed to be essential for maintaining current water balances. The monolayer-ET cover will be revegatated with native plant species.

Localized infiltration may also occur if storm run-on is captured by depressions on the site cover. Previous studies have shown that a 100-y flood zone occurs along the southwest border of the Area 5 RWMS and that the operationally active area of the site is not located within the flood zone. The site is currently protected from a 25-y, 24-hour flood event by engineered berms, levee extensions, and flood control channels. Construction of closure covers above grade has also been identified as a design feature mitigating the potential for infiltration of run-on. Closure covers 
will be constructed above grade and contoured to reduce the potential for infiltration of storm water runoff.

\subsubsection{Natural Resources}

Disposal systems must be sited at locations where attractive natural resources are not present. Resources to be considered include minerals, petroleum or natural gas, valuable geologic formations, and ground waters that are either irreplaceable because there is no reasonable alternative source of drinking water available for substantial populations or that are vital to the preservation of unique and sensitive ecosystems.

Several assessments show that the Area 5 RWMS is not sited near any significant economic mineral deposits, viable petroleum or natural gas deposits, valuable geologic formations, or irreplaceable sensitive water supplies. The Area 5 RWMS is located on an alluvial fan, in an arid, remote, alluvium-filled basin, with deep groundwater. Biological studies show the Area 5 RWMS is not located near unique or sensitive ecosystems.

Gustafson et al. (2007) identified potentially exploitable resources near the Area 5 RWMS that could lead to inadvertent human intrusion after active IC ends. They considered sand and gravel, minerals, petroleum, and water. Quality, quantity, availability of better sources, transport costs, and limited local demand are likely to limit commercial extraction of geologic economic resources in the NNSS region.

Gustafson et al. (2007) also reviewed examinations of rural land use potential (Case et al. 1984; Richard-Haggard 1983) and concluded that alternative land uses such as agriculture, grazing, and hunting do not appear to be potential causes for inadvertent human intrusion.

\section{Sand and Gravel Resources}

Although sands and gravels are located in the upper alluvium at the Area 5 RWMS, the quality of the material is poor and the location is far from the most likely sources of demand for roadways, building pads, and other fill structures. Samples of alluvium from excavations in the Area 5 RWMS indicate the shallow gravels are composed of fragments of predominantly pyroclastic volcanic rocks derived from nearby exposures in the Half Pint range. The pyroclastic volcanic rocks are too friable to be suitable for many typical commercial uses. Current existing population centers (Alamo, Beatty, and Pahrump) and major highways are far from the Area 5 RWMS. If development were to occur in the Frenchman Flat region in the future, gravel resources are more likely to be extracted from the south side of the basin where the material may be higher quality because carbonate rocks are more prevalent (Gustafson et al. 2007).

\section{Mineral Resources}

There is no record of historic mining activities within Frenchman Flat. Four mining districts have been identified on the NNSS: Calico Hills, Wahmonie, Mine Mountain, and Oak Spring. The nearest recorded mineral deposits are $23 \mathrm{~km}(14 \mathrm{mi})$ northwest of the Area 5 RWMS in the Mine Mountain Mining District. 
The economic mineral potential of these districts was summarized by Shott et al. (1998). Silver may be present in the Oak Spring District. Potentially economic mineral deposits may remain in the Wahmonie District. Commercial tungsten mining occurred in the Oak Spring District in the 1950s and early 1960s. The NNSS is considered to have a moderate potential for tungsten skarn deposits. Molybdenum is associated with these deposits. Although these sites may be developed in the future, they are relatively distant from the Area 5 RWMS.

Although there are natural zeolites in some of the volcanic tuffs underlying Frenchman Flat, the likelihood of the Area 5 RWMS being mined for zeolites is very low. Only one of the ten companies that mined natural zeolites in the U.S. in 2005 was located in Nevada, and the U.S. produced less than 3\% of the world production in 2005. The main domestic uses for natural zeolites are for animal feed, water purification, and pet litter (Virta 2006). There are alternative materials for these products. Many commercial industrial applications use synthesized zeolites for their purity and unique characteristics. Most U.S. foreign trade in zeolites is in synthetic zeolite products (Virta 2006).

Projections for growth in demand and production of natural zeolites in the U.S. are modest. New products and markets, such as lightweight aggregate for specialty concrete products are in development. Based on recent trends, the U.S. Geological Survey predicts U.S. production and sales of natural zeolites will increase by at least 4\% to 5\% per y (Virta 2006).

Natural zeolite resources, however, are not unique to the Frenchman Flat area. There are existing operations in the U.S. extracting higher quality and more accessible material. In the unlikely event that a local market for zeolites would ever develop within the NNSS, the mid-fan location of the Area 5 RWMS is less likely to be a viable source than volcanic tuffs in alkaline lake deposits or surface outcrops of volcanic rocks with higher zeolite contents.

\section{Petroleum Resources}

Petroleum exploration in Nevada has been very limited. Petroleum had been produced from wells in Railroad Valley, approximately $150 \mathrm{~km}(92 \mathrm{mi})$ north of the Area 5 RWMS and in the Blackburn Field, Eureka County, approximately 370 km (230 mi) north of the Area 5 RWMS. The potential for oil and natural gas is rated low for Southern Nye County in two Nevada Bureau of Mines and Geology Reports (Garside et al. 1988; Castor et al. 1990). Four oil and gas exploration holes within $64 \mathrm{~km}$ (40 mi) of the Area 5 RWMS developed before 1992, ranging in depth from 447 to $1,702 \mathrm{~m}$ (1,468 to 5,583 ft), were dry holes.

\section{Groundwater and Surface Water Supplies}

Pilot wells at the Area 5 RWMS indicate depth to groundwater is about $236 \mathrm{~m}$ (775 ft) (BN 2005). The results from the pilot wells indicate the groundwater is good quality in the immediate vicinity of the Area 5 RWMS. These wells tap the uppermost alluvial aquifer, which is not regionally extensive and is locally impacted by radionuclides in the vicinity of nearby nuclear tests that were conducted below or near the water table. Many CAUs have been identified in Frenchman Flat, and the Area 5 RWMS is inside the planned UR boundary established for the Frenchman Flat UGTA (CAU 98). 
Gustafson et al. (2007) identifies at least three potential uses for groundwater from the aquifer, assuming the aquifer is accessible and there is water in sufficient quantity: agricultural irrigation, commercial geothermal energy development, and human consumption. However, the cost of developing deep wells and pumping groundwater makes these uses unlikely. The nearest spring is Cane Spring, about $14.3 \mathrm{~km}$ (8.8 mi) west of the Area 5 RWMS. Future settlers are more likely to locate near such surface water resources.

\section{Important Habitats}

Unique and sensitive areas of the NNSS have been identified through biological studies. The Area 5 RWMS is not within an area identified as "important habitat" based on high species diversity, uniqueness, pristineness, or sensitive habitat that would be slow to recover from disturbances (DOE/NV 1998b). The floral community at the Area 5 RWMS is classified as a Larrea tridentata-Ambrosia dumosa assemblage, a common community within the Mojave Desert.

Large portions of the NNSS are within the range of the Western burrowing owl, which is protected by the State of Nevada. There is no evidence that Area 5 RWMS operations have affected the owls, which often reside in culverts and abandoned conduit pipes. The Area 5 RWMS is also within the range of the desert tortoise, a threatened species protected under the Endangered Species Act, but in an area of relatively low abundance. Activities within tortoise habitat are conducted in accordance with a U.S. Fish and Wildlife Biological Opinion, which includes provisions for surveys, relocations, and mitigation. The NNSS Resource Management Plan (DOE/NV 1998a) and NNSS Annual Site Environmental Reports (NSTec 2012b) provide further information on monitoring and protection programs for flora, fauna, water supplies, and other critical resources of the NNSS.

\section{Agriculture and Range}

Site conditions do not appear to be favorable for intensive agriculture or livestock grazing. There are irrigable soils in Frenchman Flat, but the soils have poor water-retention characteristics. Although, it is technically feasible to produce hay crops such as alfalfa in the Frenchman Flat basin, the demand for irrigable land in southern Nevada is currently low and likely to remain low in the future. Only 5\% of the irrigable land in Nevada is in use (Richard-Haggard 1983) probably because the cost of infrastructure and power to extract water makes irrigation economically infeasible. Southern Nevada farming tends to be located near surface water or shallow groundwater supplies.

Mojave Desert plant communities are suitable for livestock grazing, but the low population density and productivity of forage shrubs and annual grasses limits the population of cattle that can be supported. Comparison of the average animal unit month for BLM grazing permits issued in Nevada to the estimated capacity of Frenchman Flat suggests that Frenchman Flat is less productive than average BLM-controlled Nevada rangeland. The greatest obstacle to livestock grazing is the lack of surface water resources requiring that deep groundwater be used or water be trucked in. The costs of obtaining water and the low productivity of the Mojave Desert make Frenchman Flat an unlikely site for grazing. 


\subsubsection{Long-Term Site Stability}

The integrity of operational covers at the Area 5 RWMS will be monitored and maintained during the active IC period. The monitoring program documents and repairs all subsided areas.

After the period of active IC, closure cover integrity will be affected by plant rooting, animal burrowing, erosion, and subsidence. The assumed effect of plant rooting and animal burrowing is to increase the porosity of surface soils. Previous calculations indicate that erosion over 1,000 y should be negligible (Shott et al. 1998; DOE/NV 1998c) and that the Area 5 RWMS is in an area of accumulating sediments. Subsidence occurring after IC is assumed to cause the formation of local depressions in the closure cover. Cracks caused by subsidence are expected to be infilled naturally by intergranular movement of unconsolidated alluvial soils used for the final closure cover.

Wastes disposed at the Area 5 RWMS are expected to subside over time. Voids within waste containers, uncompacted waste, voids between waste containers, and decomposition of organic material are all expected to contribute to the subsidence potential. A previous analysis of subsidence concluded that maximum settlement at the Area 5 RWMS could range from 1.8 to $5.5 \mathrm{~m}$ (5.9 to $18 \mathrm{ft}$ ) (DOE/NV 1998c). Wooden boxes and steel drums are expected to be 75\% degraded by $100 \mathrm{y}$. Steel boxes have the longest expected lifetime, being only 20\% degraded at $100 \mathrm{y}$. Most subsidence is expected to occur and be repaired during active site maintenance.

\subsubsection{Seismicity and Vulcanology}

Frenchman Flat is a closed basin bounded by the Halfpint Range to the north, the Ranger Mountains and the Spotted Range to the east-southeast, and Mount Salyer to the west. Elevations range from approximately 1,600 $\mathrm{m}(5,250 \mathrm{ft})$ above mean sea level in the surrounding mountain ranges to $940 \mathrm{~m}(3080 \mathrm{ft})$ at its lowest point on Frenchman Flat playa.

The Frenchman Flat basin is filled with alluvial sediments, which are 360 to $460 \mathrm{~m}$ (1,180 to $1,500 \mathrm{ft}$ ) thick below the Area 5 RWMS. The uppermost aquifer occurs at approximately $236 \mathrm{~m}$ (774 ft) depth in the alluvium. Beneath the alluvium lies a thick sequence of interbedded Tertiary welded and non-welded tuff and local lava flows. The volcanic section is estimated to be over $550 \mathrm{~m}(1,804 \mathrm{ft})$ thick and thins southeast across the basin. The lower part of the volcanic section is zeolitized and forms a confining aquifer throughout most of the basin (BN 2006b). The alluvial and volcanic sequences are underlain by an undetermined thickness of Paleozoic carbonate rocks with increased thickness of clastic rocks near the Paleozoic-Precambrian boundary (Laczniak et al. 1996).

\section{Seismic Activity}

There is a significant potential for future seismic activity in the NNSS area including Frenchman Flat during the next 1,000 y (Shott et al. 1998). The revised conceptual model of Frenchman Flat relates the origin of the Frenchman Flat basin to strike-slip faulting along the Rock Valley fault system that terminates in an extensional imbricate fan structure in the eastern margin of the basin (BN 2006b). Observational data, including historic earthquake activity, suggest that this structure is still active. Data from the Southern Great Basin Seismic Network through 2008 indicate 
earthquake return periods of $750 \mathrm{y}$ for magnitude 6 and 1,000 y for magnitude 6.5 earthquakes in a region within $65 \mathrm{~km}$ (40 mi) of the NNSS (Navarro-Intera, LLC 2010). A large magnitude earthquake event within the Frenchman Flat region is an expected event within 1,000 y, and multiple events are expected within 10,000 y.

A formal seismic risk assessment has not been conducted for the Area 5 RWMS. However, multiple lines of evidence support the conclusion that future seismic activity is unlikely to significantly degrade the isolation capability of shallow land pits and trenches.

1. There are no observed offsets in alluvial deposits within the vicinity of the Area 5 RWMS. The active parts of the Rock Valley fault system and related imbricate fault systems are $>5 \mathrm{~km}$ ( $3 \mathrm{mi}$ ) from the facility. A buried fault beneath the facility strikes northwest, a fault orientation that is not seismogenic in the current stress field (Carr 1984). Future ground ruptures from earthquake activity are not expected to disrupt the facility.

2. The most likely effect of seismic activity is ground shaking associated with a distant earthquake event. The primary concern with seismic activity ground shaking is disruption of engineered components (geomembrane barriers, leachate collection system) that can lead to increased infiltration and/or enhanced vapor-phase transport. Closure plans for the Area 5 RWMS include construction of a thick (2.5 m [8.2 ft]) monolayer-ET closure cover composed of alluvial soil. This closure cover does not contain engineered components that could fail or be disrupted by seismic events. The only anticipated effect of ground shaking is enhanced and/or accelerated compaction/subsidence.

The important infiltration, water storage, and water removal characteristics of a monolayer-ET cover are not expected to be adversely affected by minor compaction. Kemnitz (1999) completed a seismic hazard assessment for the U-3ax/bl monolayer closure cover at the Area 3 RWMS. Model parameters and site response assessments were performed for a bounding analysis to assess damage to a monolayer closure cover at the U-3ax/bl disposal cell. The controlling earthquake for the analysis is an earthquake event on the Yucca fault with a peak horizontal acceleration of $0.79 \mathrm{~g}$, where $\mathrm{g}$ is the acceleration of gravity. The maximum predicted deformation of the closure cover is between 2 and $8 \mathrm{~cm}$ (0.8 and 3 in.) (lateral and differential deformation). These deformations are insignificant compared to the expected subsidence in the closure cover (Kemnitz 1999). The effects of future seismic events are not important for the Area 5 RWMS monolayer-ET closure cover.

\section{Potential for Volcanic Activity}

The volcanic record of the NNSS was summarized in the Area 5 RWMS PA (Shott et al. 1998). Silicic volcanism in the region ceased following eruptions associated with the Black Mountain caldera about 8.5 million years ago (Ma) (Sawyer et al. 1994). Small-volume basaltic volcanism persisted in the region following cessation of silicic volcanism. All Quaternary basaltic volcanic activity in the NNSS region is confined to the western and southwest parts of the region, including the basalt of Sleeping Butte, the Quaternary basalt of Crater Flat, and the Lathrop Wells volcanic center (Crowe 1990; Fleck et al. 1996; Heizler et al. 1999). Basaltic volcanism in 
the Frenchman Flat basin includes buried basalt encountered in the alluvial section in multiple drillholes, including the UGTA northern drillhole cluster (Carr et al. 1975; BN 2005). The age of these buried basalt lavas is about 8.5 Ma (Raytheon Services Nevada 1994). Local vents for the buried basalt are present in Scarp Canyon, immediately north of Frenchman Flat (Crowe 1990). The youngest basalt centers in the basin vicinity are the basalt of Nye Canyon. This volcanic unit consists of three basalt centers aligned along a north-northeast trend, and the centers have been dated at about 7.3 Ma (Raytheon Services Nevada 1994).

The absence of nearby Pliocene or Quaternary basaltic volcanism in the Frenchman Flat area is the primary basis for an assessment of minimal risk to the Area 5 RWMS from the recurrence of future volcanism. The nearest site of Quaternary basaltic volcanism is the Lathrop Wells center, over $50 \mathrm{~km}$ (31 mi) from the Area 5 RWMS. The absence of young volcanic centers in the area classifies the facility as removed from zones of active volcanism and in a setting of background volcanic rates for the southern Great Basin. Background volcanic rates for the southern Great Basin region have been estimated by multiple researchers. Crowe et al. (1998) calculated a Quaternary recurrence rate of $3.7 \times 10^{-6}$ events $\mathrm{y}^{-1}$ for post-caldera basaltic volcanism within an area encompassing the NNSS region and including Frenchman Flat. The likelihood of magmatic disruption of a 2.5-square kilometer $\left(\mathrm{km}^{2}\right)$ (1-square mile $\left.\left[\mathrm{mi}^{2}\right]\right)$ area equivalent to the dimensions of the Area 5 RWMS using this recurrence rate is $2 \times 10^{-9}$ events $\mathrm{y}^{-1}$. Connor et al. (2000) calculated an event rate of $1.3 \times 10^{-9}$ events $\mathrm{y}^{-1}$ per $\mathrm{km}^{2}$ for the last $2.0 \mathrm{Ma}$ for the western Great Basin. Application of this rate to a $2.5 \mathrm{~km}^{2}\left(1 \mathrm{mi}^{2}\right)$ facility area gives a volcanic disruption probability of $3.2 \times 10^{-9}$ events $\mathrm{y}^{-1}$. These event rates are equal to a disruption probability of about 1 in 300 million per y, a sufficiently low probability to dismiss volcanism as a concern for the Area 5 RWMS.

\subsection{Waste Characteristics}

\subsubsection{Area 5 RWMS Waste Inventory}

The Area 5 RWMS inventory disposed from September 26, 1988, through FY 2011 was estimated probabilistically with the Area 5 Inventory v2.108 GoldSim model. Uncertainty in the radionuclide inventories are represented using lognormal distributions. The FY 2011 inventory geometric means and geometric standard deviations have been reported previously (NSTec 2012a). The entire post-1988 inventory was used in the SA, including inventories for the SLB disposal units, the Pit 6 Radium Disposal Unit (RaDU), the Pit 13 RaDU, and the post-1988 Greater Confinement Disposal Boreholes. Future inventory estimates are not included in the analysis.

\subsubsection{CEUSP Waste Inventory}

The OR CEUSP waste stream inventory is estimated from the waste profile (Duratek 2012). On an activity basis the waste is predominantly ${ }^{232} \mathrm{U}$ and ${ }^{233} \mathrm{U}$ (Table 2.4). On a mass basis the waste is predominantly ${ }^{235} \mathrm{U}$ (Isotek 2012a). The waste includes several TRU radionuclides as trace contaminants but is not TRU waste. 
Table 2.4 OR CEUSP waste stream geometric means and geometric standard deviations at the time of disposal

\begin{tabular}{|c|c|c|}
\hline Nuclide & Geometric Mean (Bq) & $\begin{array}{c}\text { Geometric Standard } \\
\text { Deviation }\end{array}$ \\
\hline${ }^{229} \mathrm{Th}$ & $1.5 \mathrm{E}+11$ & 2.01 \\
\hline${ }^{230} \mathrm{Th}$ & $5.3 \mathrm{E}+10$ & 1.99 \\
\hline${ }^{232} \mathrm{U}$ & $1.0 \mathrm{E}+14$ & 2.01 \\
\hline${ }^{233} \mathrm{U}$ & $4.8 \mathrm{E}+13$ & 2.01 \\
\hline${ }^{234} \mathrm{U}$ & $4.3 \mathrm{E}+12$ & 2.04 \\
\hline${ }^{235} \mathrm{U}$ & $8.5 \mathrm{E}+10$ & 1.99 \\
\hline${ }^{236} \mathrm{U}$ & $1.9 \mathrm{E}+11$ & 2.00 \\
\hline${ }^{238} \mathrm{Pu}$ & $8.5 \mathrm{E}+08$ & 1.99 \\
\hline${ }^{239} \mathrm{Pu}$ & $3.5 \mathrm{E}+07$ & 1.98 \\
\hline${ }^{240} \mathrm{Pu}$ & $1.8 \mathrm{E}+07$ & 2.02 \\
\hline${ }^{241} \mathrm{Am}$ & $1.4 \mathrm{E}+08$ & 2.00 \\
\hline
\end{tabular}

The waste stream inventory is assumed to be lognormally distributed. The geometric mean inventory is estimated as the product of the waste stream volume, $2.66 \mathrm{~m}^{3}$, and the representative activity concentration. The geometric standard deviation is estimated assuming that the upper limit concentration on the waste profile sheet is the $95^{\text {th }}$ percentile of the lognormal distribution.

The inventory of long-live radionuclides in the CEUSP ${ }^{233} \mathrm{U}$ waste stream has two peak activities. The first and largest peak occurs at disposal and is due to ${ }^{232} \mathrm{U}$ and ${ }^{228} \mathrm{Th}$ (Figure 2.2). The ${ }^{232} \mathrm{U}$ and ${ }^{228} \mathrm{Th}$ inventory decays with the 68.9 y half-life of ${ }^{232} \mathrm{U}$. A second minor peak occurs at approximately 29,000 y as ${ }^{229}$ Th and its short-lived progeny reach secular equilibrium with ${ }^{233} \mathrm{U}$. After $29,000 \mathrm{y}$, the ${ }^{233} \mathrm{U}$ and ${ }^{229} \mathrm{Th}$ activity decays slowly with the $1.6 \times 10^{5}$ y half-life of ${ }^{233} \mathrm{U}$, and ${ }^{233} \mathrm{U}$ and ${ }^{229} \mathrm{Th}$ remain as the predominant radionuclides until approximately 1.5 million y. At 1.5 million y, ${ }^{236} \mathrm{U}$ becomes the most abundant CEUSP radionuclide on an activity basis. The CEUSP ${ }^{236} \mathrm{U}$ inventory is an insignificant fraction of the Area 5 RWMS ${ }^{236} \mathrm{U}$ inventory. Because the CEUSP waste stream reaches its peak activities at much earlier times than the Area 5 RWMS inventory, the peak dose from the CEUSP waste stream is also expected to occur before the peak Area 5 RWMS dose. 


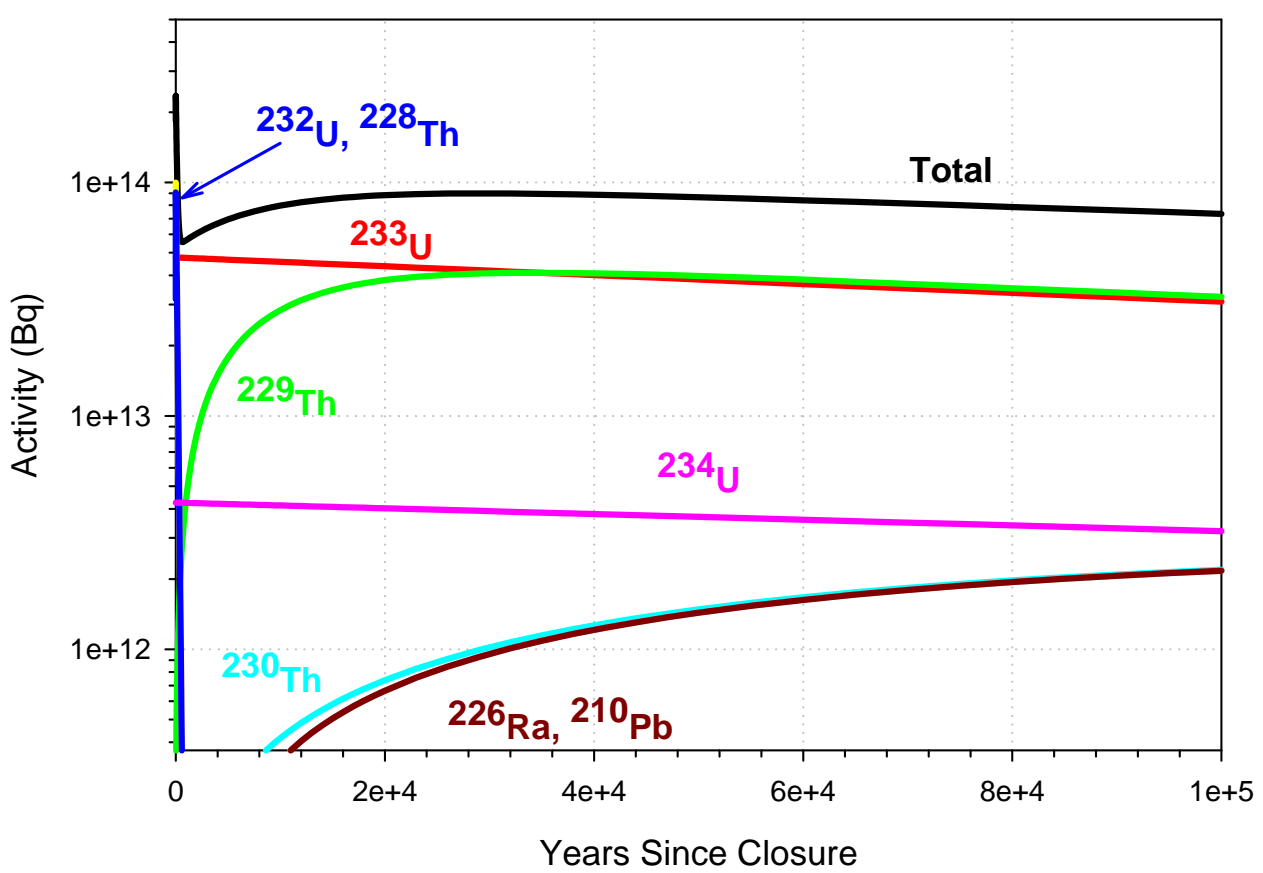

Figure 2.2 Inventory time history of long-lived radionuclides in the CEUSP ${ }^{233} \mathrm{U}$ waste stream.

Key radionuclides are defined as the radionuclides responsible for most of the risk posed by a waste stream. Selection of key radionuclides is based on consideration of concentration, half-life, radiological hazard, and mobility. The CEUSP ${ }^{233} \mathrm{U}$ waste stream key radionuclides are judged to be ${ }^{228} \mathrm{Th}+\mathrm{P},{ }^{229} \mathrm{Th}+\mathrm{P},{ }^{232} \mathrm{U}$, and ${ }^{233} \mathrm{U}$. The “+P” notation indicates that short-lived progeny assumed to be in secular equilibrium is included. Although the CEUSP ${ }^{233} \mathrm{U}$ waste stream includes significant concentrations of ${ }^{230} \mathrm{Th},{ }^{234} \mathrm{U}$, and ${ }^{235} \mathrm{U}$, these radionuclides are not considered key because the total activity contained in the waste stream is an insignificant fraction of the inventory already disposed in the Area 5 RWMS.

\subsubsection{CEUSP Waste Form and Containers}

The CEUSP ${ }^{233} \mathrm{U}$ originated from the neutron irradiation of $\mathrm{ThO}_{2}-\mathrm{UO}_{2}$ fuel in the Consolidated Edison Indian Point Rector 1. The uranium was separated from the irradiated fuel and recovered in a uranyl nitrate solution. Cadmium nitrate and gadolinium oxide were added to the solution for criticality control. The uranyl nitrate solution was solidified and denitrified to $\mathrm{U}_{3} \mathrm{O}_{8}$ by drop-wise introduction of the solution into stainless steel canisters heated to 750 degrees Celsius $\left({ }^{\circ} \mathrm{C}\right)$. The final waste form is a ceramic-like monolith of solidified $\mathrm{U}_{3} \mathrm{O}_{8}$ highly enriched in ${ }^{233} \mathrm{U}$ and ${ }^{235} \mathrm{U}$.

The CEUSP ${ }^{233} \mathrm{U}$ waste is contained in 403 weld-sealed 304L stainless steel canisters, approximately $62 \mathrm{~cm}$ (24 in.) long and $9 \mathrm{~cm}$ (3.5 in.) in diameter (Isotek 2012b). The minimum wall thickness of the stainless steel canister is $0.21 \mathrm{~cm}(0.083 \mathrm{in}$.). The stainless steel canisters are over-packed in a thin-walled, tin-plated steel container.

For disposal, the CEUSP canisters will be packed in sealed disposal sleeves constructed from Schedule 40 carbon steel pipe. Each sleeve is approximately $446 \mathrm{~cm}$ (176 in.) long and $11 \mathrm{~cm}$ 
(4.5 in.) in diameter (Isotek 2012b). The minimum disposal sleeve wall thickness is $0.61 \mathrm{~cm}$ (0.24 in.).

The stainless steel canister and the steel disposal sleeve are expected to fail over time as they corrode due to contact with soil and the $\mathrm{U}_{3} \mathrm{O}_{8}$ waste. Corrosion of steel in soil can proceed by general corrosion and localized corrosion. General corrosion is assumed to proceed uniformly over the entire surface at a constant rate (Sullivan 2003; Subramanian 2007). Localized corrosion or pitting describes the stochastic formation of hemispherical pits of variable size and depth on the surface.

General corrosion rates of carbon and stainless steel have been measured over a 12 y period in the arid soils at the Idaho National Laboratory (Table 2.5). These data are used to assign general corrosion rates to carbon and stainless steel based on a maximum entropy approach, which chooses a probability density function (pdf) that maximizes entropy given known constraints (a range, mean, variance, etc.). The selected distributions preserve the information available while maximizing uncertainty. Triangular distributions were chosen using the mean and range of the data in Table 2.5. With these assumptions, the stainless steel general corrosion distribution is assumed to be $\mathrm{T}\left(8 \mathrm{E}-10,9.2 \mathrm{E}-9,2.7 \mathrm{E}-8 \mathrm{~m} \mathrm{y}^{-1}\right)$ and the carbon steel corrosion rate is $\mathrm{T}(2.5 \mathrm{E}-6$, 7.4E-6, 1.2E-5 $\mathrm{m} \mathrm{y}^{-1}$ ), where $\mathrm{T}(\bullet, \bullet, \bullet)$ denotes triangular distribution (minimum, mode, maximum).

Table 2.5 General corrosion rates for steel buried in arid vadose zone soils at the Idaho National Laboratory

\begin{tabular}{|c|c|c|}
\hline Material & Corrosion Rate & Source \\
\hline \multirow{4}{*}{$\begin{array}{c}\text { 304L Stainless Steel } \\
\text { (Unified Numbering }\end{array}$} & $5.8 \mathrm{E}-9-1.5 \mathrm{E}-8 \mathrm{~m} \mathrm{y}^{-1}$ & Adler Flitton et al. 2001, p. V-VI \\
\cline { 2 - 3 } $\begin{array}{c}\text { System } \\
\text { [UNS] S30403) }\end{array}$ & $6.35 \mathrm{E}-9-8.3 \mathrm{E}-9 \mathrm{~m} \mathrm{y}^{-1}$ & Adler Flitton et al. 2002, Tables 2 and 3 \\
\cline { 2 - 3 } & $2.7 \mathrm{E}-8 \mathrm{~m} \mathrm{y}^{-1}$ & Riley and Lo Presti 2004, p. 8.2 \\
\cline { 2 - 3 } & $8 \mathrm{E}-10 \mathrm{~m} \mathrm{y}^{-1}$ & Riley and Lo Presti 2004, p. C.1 \\
\cline { 2 - 3 } & $6.1 \mathrm{E}-9 \mathrm{~m} \mathrm{y}^{-1}$ & Riley and Lo Presti 2004, p. C.1 \\
\cline { 2 - 3 } & $4.8 \mathrm{E}-9 \mathrm{~m} \mathrm{y}^{-1}$ & Riley and Lo Presti 2004, p. C.1 \\
\hline \multirow{3}{*}{$\begin{array}{c}\text { Low Carbon Steel } \\
\text { (UNS G10180) }\end{array}$} & $8.4 \mathrm{E}-9 \mathrm{~m} \mathrm{y}^{-1}$ & Riley and Lo Presti 2004, p. C.1 \\
\cline { 2 - 3 } & $1.17 \mathrm{E}-5 \mathrm{~m} \mathrm{y}^{-1}$ & Adler Flitton et al. 2001, p. V-VI \\
\cline { 2 - 3 } & $3.1 \mathrm{e}-6-1.1 \mathrm{E}-5 \mathrm{~m} \mathrm{y}^{-1}$ & Adler Flitton et al. 2002, Tables 2 and 3 \\
\cline { 2 - 3 } & $8.7 \mathrm{E}-6 \mathrm{~m} \mathrm{y}^{-1}$ & Adler Flitton and Yoder 2006, Table 3 \\
\cline { 2 - 3 } & $2.5 \mathrm{E}-6 \mathrm{~m} \mathrm{y}^{-1}$ & \\
\hline
\end{tabular}

Pressurization by gasses is another potential mechanism for breaching of containers. The CEUSP ${ }^{233} \mathrm{U}$ waste contains no hydrogen and has no potential for radiolytic generation of gases (Isotek 2012a). The CEUSP ${ }^{233} \mathrm{U}$ waste will generate ${ }^{219} \mathrm{Rn},{ }^{220} \mathrm{Rn}$, and ${ }^{222} \mathrm{Rn}$ by radioactive decay. The maximum volume of radon gas of each isotope will occur when each $\mathrm{Rn}$ isotope reaches secular equilibrium with its parent. The volume of radon gas, as a perfect gas at standard temperature and pressure, can be calculated as: 


$$
V=\sum_{i=1}^{3}\left(A_{i} \frac{t_{1 / 2, i}}{\ln (2)} \frac{\text { mole }}{6.022 E 23 \text { atoms }} \frac{0.024 \mathrm{~m}^{3}}{\text { mole }}\right)
$$

where

$$
\begin{array}{lll}
V & = & \text { total radon gas volume, } \mathrm{m}^{3} \\
A_{i} & = & \text { maximum activity (i.e., activity at equilibrium) of radon isotope } i, \mathrm{~Bq} \\
t_{1 / 2, i} & = & \text { half-life of isotope } i, \mathrm{~s}
\end{array}
$$

Assuming the waste stream inventory is evenly divided among 403 canisters, the maximum volume of radon gas that could be present in an average canister is $2.1 \mathrm{E}-4 \mathrm{~cm}^{3}$ (Table 2.6). Assuming the average canisters are half full of waste, the total gas head space is approximately $600 \mathrm{~cm}^{3}$ per canister. The maximum volume of radon gas, $2.1 \mathrm{E}-4 \mathrm{~cm}^{3}$, is not sufficient to pressurize a CEUSP canister with $600 \mathrm{~cm}^{3}$ of gas head space.

Table 2.6 Maximum radon gas production in CEUSP canisters

\begin{tabular}{|c|c|c|c|}
\hline Nuclide & $\begin{array}{c}\text { Maximum Activity per } \\
\text { Canister (Bq) }\end{array}$ & Half-Life (s) & $\begin{array}{c}\text { Radon Gas Volume per Canister } \\
\text { at } \mathbf{1} \text { Atmosphere and } \mathbf{2 5}^{\circ} \mathbf{C} \mathbf{~ ( c m}^{\mathbf{3}} \mathbf{)}\end{array}$ \\
\hline${ }^{219} \mathrm{Rn}$ & $2.1 \mathrm{E}+08$ & 3.96 & $4.9 \mathrm{E}-11$ \\
\hline${ }^{220} \mathrm{Rn}$ & $2.5 \mathrm{E}+11$ & 55.6 & $8.2 \mathrm{E}-07$ \\
\hline${ }^{222} \mathrm{Rn}$ & $1.1 \mathrm{E}+10$ & $3.30 \mathrm{E} 5$ & $2.0 \mathrm{E}-04$ \\
\hline Total & & & $2.1 \mathrm{E}-04$ \\
\hline
\end{tabular}




\subsection{Methods}

\subsection{Model Development}

The Area 5 RWMS is well suited for waste disposal and amenable to relatively simple PA models. An important simplifying feature is that a groundwater pathway is extremely unlikely. In addition, the site is located within laterally extensive alluvial deposits that are relatively homogenous in the horizontal plane. This allows one-dimensional model implementation in the vertical plane.

Screening of a comprehensive list of FEPs has produced a relatively short list of processes and events that may potentially transport radionuclides. All transport pathways move radionuclides upwards to the land surface. Natural FEPs that influence radionuclide release and transport over 10,000 y are the following:

- Upward liquid advection

- Liquid-phase diffusion

- Precipitation/dissolution of solutes

- Adsorption on solid surfaces

- Existence of a no liquid flux boundary above which no upward liquid phase transport occurs due to the disconnected liquid phase at low water contents

- Gas-phase diffusion

- Animal burrow excavation and collapse

- Plant root uptake, aboveground translocation, and senescence

- Radioactive decay and ingrowth

- Climate change

A climate change model was previously implemented for an SA of the TRU waste in Trench T04 (Shott et al. 2008). The results of this model indicate that climate change had minimal impacts on the maximum dose received by a resident. This SA does not include a climate change model based on the previous results, which showed that climate change effects were minimal and tended to reduce dose. All other FEPS listed above are included in the model.

Once radionuclides are released to surface soil and the atmosphere, the total effective dose (TED) is estimated for a resident at the $100 \mathrm{~m}$ (330 ft) site boundary. The resident is exposed though external irradiation from soil and by immersion in air, inhalation of gases and resuspended soil, dermal adsorption of ${ }^{3} \mathrm{H}$, and inadvertent soil ingestion. Ingestion of agricultural products is not included in the resident scenario as this is not expected at a site without water resources. In addition to the resident scenario, additional scenarios including a transient occupant scenario, resident farmer scenario, and open rangeland scenarios are evaluated to assess scenario uncertainty. A complete description of the model and its scenarios can be found in PA documents (Shott et al. 1998; BN 2006a) and in documentation included within the model itself. 
The SA analyses are performed with a computer model that uses the GoldSim probabilistic simulation platform. Model results are generated using Monte Carlo simulation. The Monte Carlo simulation process begins by randomly sampling input parameter distributions that represent uncertainty in the parameter value to obtain a single set or realization of parameter values. The random sample of parameters values is propagated through the model to obtain a single model result. The process is repeated many times, with each realization having a different random set of input values, until a distribution of output values is obtained. The distribution of the output values represents uncertainty in the model result.

\subsubsection{Waste Form and Container Failure}

Relatively little is known about the long-term performance of the waste form disposed in soil. The model assumes that the waste form completely releases its radionuclides to soil upon failure of the container. The monolithic ceramic-like character of the waste form makes this a conservative assumption.

The CEUSP ${ }^{233} \mathrm{U}$ waste stream will be disposed in a robust container system consisting of an inner weld-sealed stainless steel canister and an outer carbon steel disposal sleeve. A simple corrosion model is developed and added to the baseline model for additional analyses performed to assess the impacts of containers on the near-field release of the CEUSP ${ }^{233} \mathrm{U}$ waste. Two corrosion processes are considered. General or uniform corrosion refers to the relatively uniform reduction in thickness occurring over the entire surface of the metal. Pitting corrosion is localized corrosion caused by corrosive micro-environments. Corrosive micro-environments can arise due to a passive surface film that has failed or local heterogeneity in soil chemistry.

The carbon steel disposal sleeve is assumed to undergo general corrosion on the outside surface facing the soil only. The inner stainless steel canister is assumed to corrode on the inside surface facing the $\mathrm{U}_{3} \mathrm{O}_{8}$ waste from time zero. The outer surface of the stainless steel canister is assumed to start corroding when the carbon steel disposal sleeve fails. Once the disposal sleeve fails, the stainless steel canister general corrosion rate doubles because corrosion is occurring on two surfaces. General corrosion is assumed to occur at constant rates over time.

Localized or pitting corrosion is also assumed to occur. The maximum pit depth as a function of time can be fit by a power function of the form (Sullivan 2003; Subramanian 2007):

$$
h=k t^{n}\left(\frac{A}{372}\right)^{a}
$$

where

$\begin{array}{lll}h & = & \text { maximum corrosion pit depth, } \mathrm{m} \\ k & = & \text { empirical pitting parameter, } \mathrm{m} \mathrm{y}^{-\mathrm{n}} \\ t & = & \text { elapsed time, } \mathrm{y} \\ n & = & \text { empirical pitting exponent } \\ A & = & \text { surface area, } \mathrm{m}^{2} \\ a & = & \text { empirical correlation coefficient }\end{array}$


The pitting exponent is calculated using an empirical equation from Mughabghab and Sullivan (1989) for well aerated soil:

$$
n=\frac{\theta_{v}}{1-\frac{\rho_{b}}{\rho_{p}}}(1-C L)^{0.4}
$$

where

$$
\begin{array}{lll}
\theta_{v} & = & \text { volumetric water content, } \mathrm{m}^{3} \mathrm{~m}^{-3} \\
\rho_{b} & = & \text { soil bulk density, } \mathrm{g} \mathrm{cm}^{-3} \\
\rho_{p} & = & \text { particle bulk density, } \mathrm{g} \mathrm{cm}^{-3} \\
C L & = & \text { fraction of soil as clay }
\end{array}
$$

The volumetric water content, dry soil bulk density, and particle density pdfs are already included in the A5 RWMS v4.113 model and available in model documentation. Additional parameters are specified in Table 3.1.

Table 3.1 Carbon steel pitting model parameters

\begin{tabular}{|c|c|c|}
\hline Parameter & Distribution or Value & Source \\
\hline$K$ & $\mathrm{~T}\left(3.0 \mathrm{E}-4,8.3 \mathrm{E}-4,1.2 \mathrm{E}-3 \mathrm{~m} \mathrm{y}^{-\mathrm{n}}\right)$ & $\begin{array}{c}\text { Mughabghab and Sullivan 1989, Table I } \\
\text { Assumes soil } \mathrm{pH}>7.5\end{array}$ \\
\hline$C L$ & 0.1 & Blout et al. 1995, p. 3-17 \\
\hline$a$ & $\mathrm{~T}(0.08,0.15,0.32)$ & Sullivan 2003, p. 10 \\
\hline
\end{tabular}

No data were found for localized corrosion or pitting corrosion of stainless steels in soils except that no detectable corrosion occurs over 12 to 18 y (Romanoff 1957; Adler Flitton and Yoder 2012). Localized corrosion is a likely failure mode for stainless steel. Pitting corrosion of the stainless steel canister was simulated using the carbon steel model with adjustments for the thickness and area of the canister. Stainless steel pitting corrosion is assumed to be delayed $18 \mathrm{y}$ relative to carbon steel.

\section{Time to Failure}

The time to failure by general corrosion can be calculated as (Sullivan 2003; Subramanian 2007):

where

$$
t_{i f}=\frac{d_{i}}{g_{i}}
$$

$$
\begin{array}{lll}
t_{i f} & = & \text { time to failure of material } i, \mathrm{y} \\
d_{i} & = & \text { degradation allowance thickness for material } i, \mathrm{~m} \\
g_{i} & = & \text { generalized corrosion rate of for material } i, \mathrm{~m} \mathrm{y}^{-1}
\end{array}
$$

The degradation allowance thickness is less than the container thickness and accounts for the expectation that mechanical failure of the container will occur before complete corrosion. For general corrosion, the degradation allowance was assumed to be uniformly distributed from 0.5 to 0.9 times the minimum container thickness. 
Setting the maximum pit depth equal to the container thickness, the time to failure by pitting can be calculated as:

$$
t_{i f}=\left[\frac{x_{i}}{k}\left(\frac{372}{A}\right)^{a}\right]^{1 / n}
$$

where

$$
x \quad=\quad \text { thickness of metal } i, \mathrm{~m}
$$

The carbon steel disposal sleeve time to failure, $t_{C S f}$, is then the minimum of the two competing corrosion processes or:

$$
t_{C S f}=\min \left\{\frac{d_{C S}}{g_{C S}},\left[\frac{x_{C S}}{k}\left(\frac{372}{A_{C S}}\right)^{a}\right]^{1 / n}\right\}
$$

Stainless steel canisters are assumed to fail by general and pitting corrosion. Because no data for pitting corrosion of stainless steel was found, pitting corrosion of stainless steel is modeled as for carbon steel with an $18 \mathrm{y}$ delay. The stainless steel canister time to failure, $t_{S S f}$, is calculated as:

$$
t_{S S f}=\min \left\{\begin{array}{ll}
\frac{d_{S S}}{2 g_{S S 1}}+\frac{t_{C S f}}{2} & \text { if } g_{S S 1} t_{C S f} \leq d_{S S} \\
d_{S S} g_{S S 1} & \text { if } g_{S S 1} t_{C S f}>d_{S S}
\end{array},\left[\frac{x_{S S}}{k}\left(\frac{372}{A_{S S}}\right)^{a}\right]^{1 / n}+18 y\right\}
$$

where $g_{S S I}$ is the one-sided stainless steel general corrosion rate. The time to complete failure of the package, $t_{p f}$, or time release to the near-field begins is calculated as:

$$
t_{p f}=\max \left(t_{S S f}, t_{C S f}\right)
$$

Corrosion model results for time of container failure are summarized in Table 3.2. In most realizations, the stainless steel canister fails before the disposal sleeve. The short time to failure is attributable to pitting corrosion and reflects the lack of data for pitting of stainless steel in soils. Early package failure is controlled by pitting corrosion of the steel disposal sleeve. Long package failure times are controlled by general corrosion of the disposal sleeve. 
Table 3.2 Statistics for time to failure, $y$, for the CEUSP disposal sleeve and stainless steel canister ( $n=5,000$ realizations)

\begin{tabular}{|c|c|c|c|c|c|c|c|}
\hline \multirow{2}{*}{ Statistic } & \multicolumn{4}{|c|}{$\begin{array}{c}\text { Low Carbon Steel Disposal Sleeve } \\
\text { Time to Failure by Process (y) }\end{array}$} & \multicolumn{2}{c|}{$\begin{array}{c}\text { Stainless Steel Canister Time to } \\
\text { Failure by Process (y) }\end{array}$} & \multirow{2}{*}{$\begin{array}{c}\text { Package } \\
\text { Failure }\end{array}$} \\
\cline { 2 - 7 } & Corrosion & Pitting & Combined & Corrosion & Pitting & Combined & \\
\hline Minimum & 260 & 12 & 12 & 20,738 & 19 & 19 & 19 \\
\hline $5 \%$ & 362 & 84 & 84 & 31,170 & 23 & 23 & 84 \\
\hline $25 \%$ & 472 & 338 & 320 & 44,811 & 32 & 32 & 321 \\
\hline Median & 584 & 930 & 477 & 62,658 & 49 & 49 & 484 \\
\hline Average & 635 & 4,081 & 485 & 78,879 & 130 & 130 & 510 \\
\hline $75 \%$ & 738 & 2,728 & 629 & 91,150 & 102 & 102 & 651 \\
\hline $95 \%$ & 1,107 & 16,501 & 928 & 183,000 & 496 & 496 & 1,007 \\
\hline Maximum & 1,932 & 318,000 & 1,788 & 696,000 & 4,718 & 4,718 & 4,718 \\
\hline
\end{tabular}

The container failure model is implemented in a special version of the PA model. The special PA model with package corrosion was created by placing the CEUSP waste inventory in the Candidate 2 source and activating the Candidate 2 Source element barrier. The Source element barrier is modeled as a single package that fails immediately at the time of package failure. Time to failure is stochastic as shown above.

\subsection{Model Application}

The SA is performed using the baseline PA model that was approved at the time the waste profile was submitted for review. This version, referred to as the A5 RWMS v4.113 GoldSim model, was developed early in FY 2012 and uses the radionuclide inventory disposed through FY 2011 (NSTec 2012a). The A5 RWMS v4.113 GoldSim model is the end result of multiple cycles of internal and external peer review (Shott et al. 1998; BN 2006a). The model is subject to annual review and updating. Baseline model releases are reviewed and approved by NNSA/NSO prior to application.

Five modeling cases were developed to assess performance of the CEUSP ${ }^{233} \mathrm{U}$ waste stream (Table 3.3). The cases differ in five areas: the radionuclide inventory, the model cell with the CEUSP ${ }^{233} \mathrm{U}$ inventory, whether or not the container failure model is used, the depth of burial, and the number of realizations.

Table 3.3 Description of modeling cases evaluated in the SA

\begin{tabular}{|c|c|c|c|c|c|}
\hline Case & Inventory & Inventory Cell & $\begin{array}{c}\text { CEUSP } \\
\text { Container Model }\end{array}$ & $\begin{array}{c}\text { Depth of } \\
\text { Burial }\end{array}$ & Realizations \\
\hline 1 & FY 2011 & SLB $^{\dagger}$ & No & Default & 5,000 \\
\hline 2 & FY 2011 and CEUSP & SLB & No & Default & 5,000 \\
\hline 3 & FY 2011 and CEUSP & Deep SLB & No & Depth 1 & 2,500 \\
\hline 4 & FY 2011 and CEUSP & Deep SLB & Yes & Depth 1 & 2,500 \\
\hline 5 & FY 2011 and CEUSP & Deep SLB & Yes & Depth 2 & 2,500 \\
\hline
\end{tabular}

${ }^{\dagger}$ - SLB - Inventory at IWastesAndMaterialsIInventoriesIPost88SLBIPost88SLB_CandidatelInventoryInput

‡ - Deep SLB - Inventory at IWastesAndMaterialsIInventoriesICandidate2_InventoryC 
Cases 1 and 2 are used for the tier I analysis assessing compliance with the DOE M 435.1-1 performance objectives. The contrast of Case 1 (no CEUSP waste) and Case 2 (with CEUSP) is used to determine the impact of disposal of the CEUSP ${ }^{233} \mathrm{U}$ waste stream. Tier I of the SA is performed by adding the CEUSP radionuclide inventory to the inventory of post-1988 SLB radionuclide disposed through FY 2011 to a default SLB trench. The mean and median model results are calculated using 5,000 Latin hypercube samples (LHS). A sample size of 5,000 has been previously shown to provide stable estimates of the mean and $95^{\text {th }}$ percentile results for an earlier version of the PA model (BN 2006a). A reasonable expectation of compliance with the performance objectives is assumed if the mean and median are less than the performance objectives. In every case, the mean was greater than the median. Only the mean results are reported in the SA.

Cases 3 through 5 are performed to assess the impacts of containers and depth of burial. These analyses address three depths of burial (Cases 2 versus Cases 3 and 4 versus Case 5). The depths of burial are ranked as Depth $2>$ Depth $1>$ Default depth. Two cases assess the effects of container failure (Case 3 versus Case 4). 


\subsection{Tier I Results: Performance Assessment}

\subsection{Performance Assessment Results}

The tier I results, which include the PA endpoint results, are generated for Cases 1 and 2. Cases 1 and 2 simulate the performance of the Area 5 RWMS inventory disposed from 1988 through FY 2011 with and without the CEUSP ${ }^{233} \mathrm{U}$ waste stream disposed in a typical SLB disposal unit. See Table 3.3 for a complete description of modeling cases.

\subsubsection{Air Pathway Dose Results}

The air pathway annual TED is evaluated for the resident exposure scenario using 5,000 LHS realizations. The resident exposure scenario estimates the dose to an adult residing in a home at the $100 \mathrm{~m}$ (330 ft) site boundary. A complete description of the exposure scenario can be found in PA documentation (BN 2006a). The annual TED is calculated for a period of 1,000 y after closure. The annual TED is zero for a 100 -y period when ICs are assumed to be $100 \%$ effective. After $100 \mathrm{y}$, ICs begin to fail probabilistically.

All realizations of the air pathway annual TED are a small fraction of the $0.1 \mathrm{mSv}$ limit throughout the 1,000-y compliance period. At $100 \mathrm{y}$, some individual TED time histories indicate the TED is decreasing as short-lived radionuclides decay while others show a slowly increasing trend.

The mean and $95^{\text {th }}$ percentile TEDs initially increase due to the increasing probability that ICs have ended (Figure 4.1). The mean and $95^{\text {th }}$ percentile TEDs are averages that include realizations with zero dose due to ICs remaining effective. The $5^{\text {th }}$ percentile TED is zero throughout the compliance period due to a greater than $5 \%$ probability that ICs will remain effective for 1,000 y or more. 


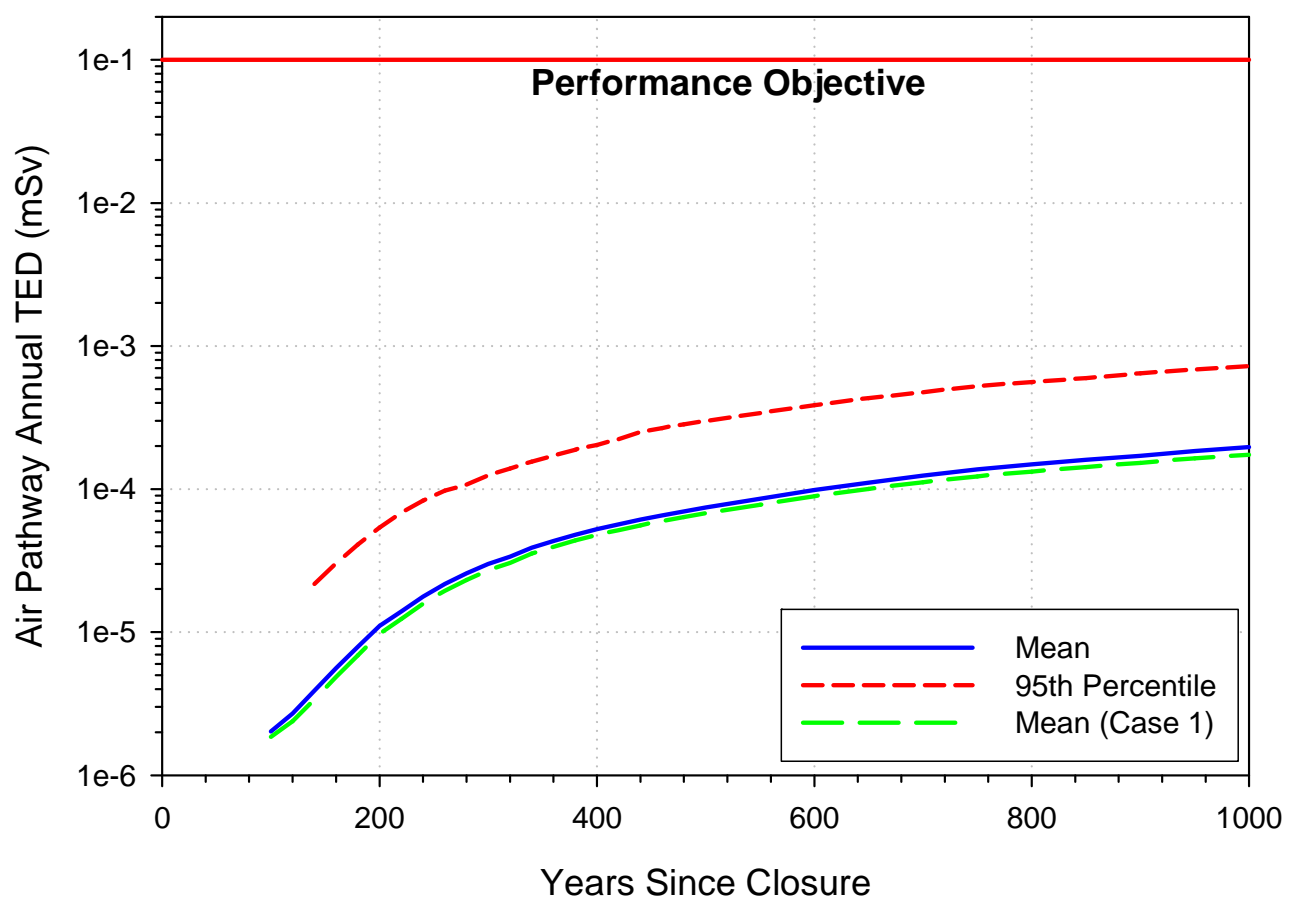

Figure 4.1 Air pathway annual TED time history for a resident at the $100 \mathrm{~m}$ site boundary (Case 2 unless otherwise noted)

The mean and $95^{\text {th }}$ percentile air pathway annual TEDs continue to increase throughout the 1,000-y compliance period. The maximum mean air pathways annual TED, 2.0E-4 mSv, occurs at $1,000 \mathrm{y}$ after closure (Table 4.1). Addition of the CEUSP ${ }^{233} \mathrm{U}$ increases the mean air pathway annual TED $18 \%$, but the maximum TED is only $0.2 \%$ of the performance objective.

Table 4.1 Resident air pathway annual TED for the FY 2011 Area 5 RWMS Inventory with and without the CEUSP ${ }^{233} \mathrm{U}$ waste stream

\begin{tabular}{|c|c|c|c|c|}
\hline $\begin{array}{c}\text { Performance } \\
\text { Objective/Scenario }\end{array}$ & \multirow{2}{*}{ Limit } & Time of Maximum & Mean (mSv) & $\begin{array}{c}9^{\text {th }} \text { Percentile } \\
\text { (mSv) }\end{array}$ \\
\hline Air Pathway/Resident (Case 1) & \multirow{2}{*}{$0.1 \mathrm{mSv}$} & $1,000 \mathrm{y}$ & $1.7 \mathrm{E}-4$ & $6.3 \mathrm{E}-4$ \\
\cline { 1 - 3 } Air Pathway/Resident (Case 2) & & $1,000 \mathrm{y}$ & $2.0 \mathrm{E}-4$ & $7.2 \mathrm{E}-4$ \\
\hline
\end{tabular}

The resident air pathway TED is caused predominantly by inhalation of resuspended soil. The dose is contributed predominantly by inhalation of ${ }^{229} \mathrm{Th}+\mathrm{P}(30 \%),{ }^{238} \mathrm{U}+\mathrm{P}(20 \%),{ }^{233} \mathrm{U}(12 \%)$, plutonium-239 $\left({ }^{239} \mathrm{Pu}\right)(11 \%)$, lead-210 $\left({ }^{210} \mathrm{~Pb}+\mathrm{P}\right)(9 \%)$, and ${ }^{234} \mathrm{U}(9 \%)$ (Figure 4.2). The “+P” notation indicates that the dose from short-lived progeny assumed to be in secular equilibrium is included. Although CEUSP waste stream key radionuclides ${ }^{229}$ Th and ${ }^{233} \mathrm{U}$ contribute significantly to the resident air pathway TED, the CEUSP waste is not the only source of these nuclides in the Area 5 RWMS inventory. 


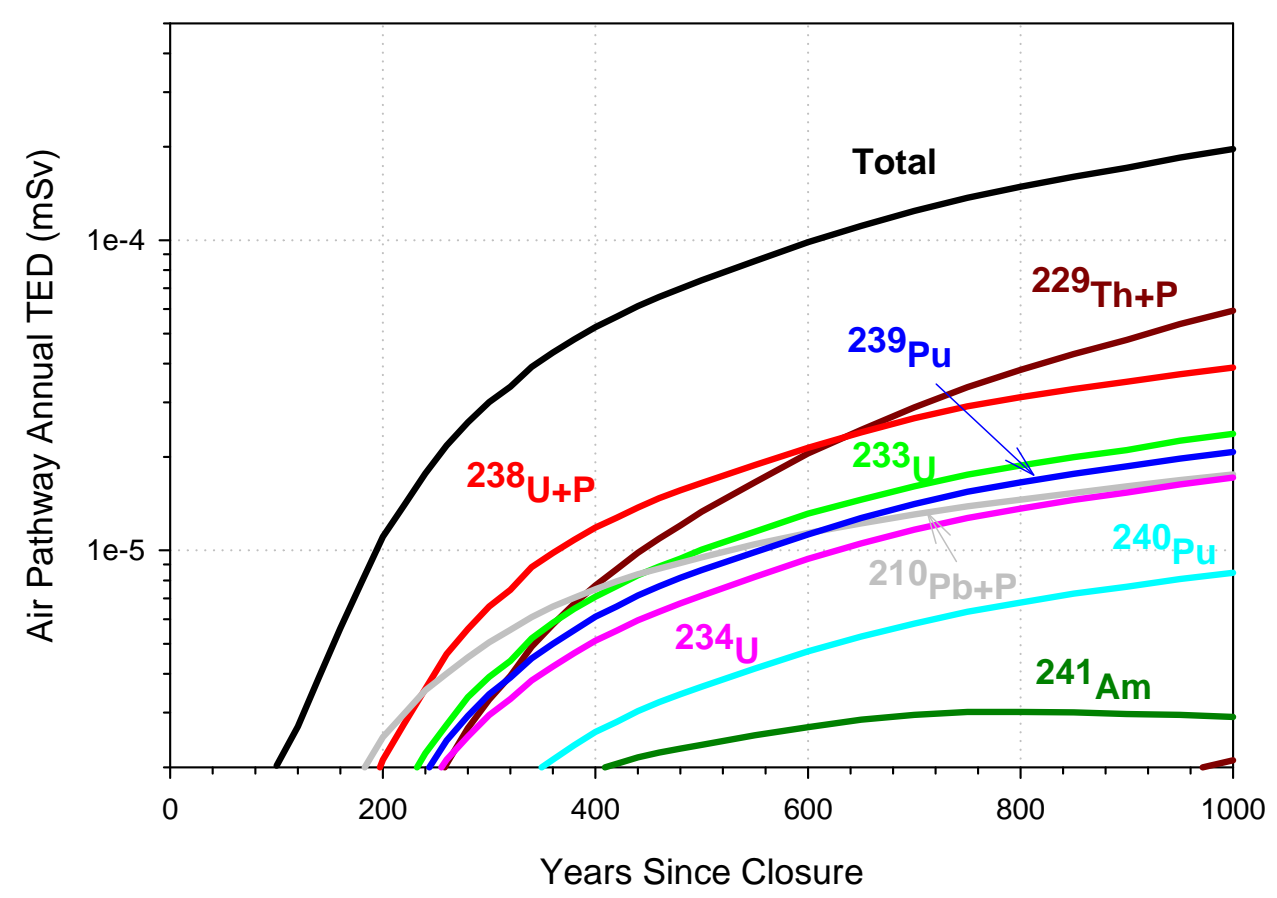

Figure 4.2 Resident air pathway annual TED time history by radionuclide

\subsubsection{All-Pathways Dose Results}

The all-pathways annual TED is also calculated for the resident exposure scenario. All 5,000 realizations are a small fraction of the $0.25 \mathrm{mSv}$ annual TED performance objective throughout the 1,000-y compliance period. At $100 \mathrm{y}$, many individual realizations are decreasing and begin to increase after a few hundred years. The mean and $95^{\text {th }}$ percentile all-pathways TEDs increase throughout the compliance period (Figure 4.3). 


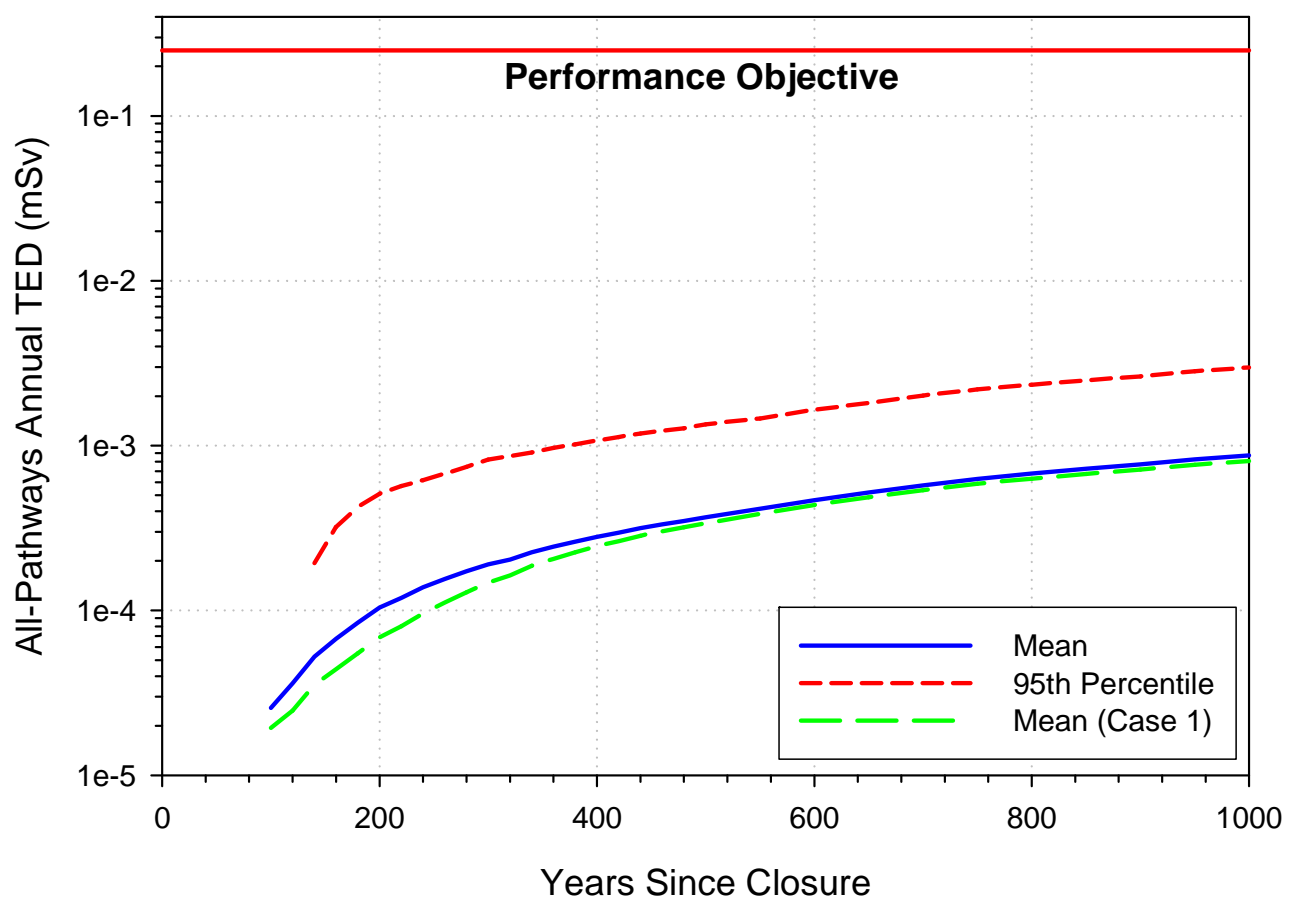

Figure 4.3 All-pathways annual TED time history for a resident at the $100 \mathrm{~m}$ site boundary (Case 2 unless otherwise noted)

The maximum mean all-pathways annual TED, 8.7E-4 mSv, occurs at 1,000 y (Table 4.2). Addition of the CEUSP ${ }^{233} \mathrm{U}$ to the SLB inventory increases the mean all-pathways annual TED by $7 \%$ at $1,000 \mathrm{y}$. The maximum mean all-pathways annual TED is $0.3 \%$ of the performance objective. A larger relative increase caused by ${ }^{228} \mathrm{Th}+\mathrm{P}$ occurs from 100 to $250 \mathrm{y}$, but the absolute dose is much less than the 1,000 y maximum.

Table 4.2 Resident all-pathways annual TED for the FY 2011 Area 5 RWMS Inventory with and without the CEUSP ${ }^{233} \mathrm{U}$ waste stream

\begin{tabular}{|c|c|c|c|c|}
\hline Performance Objective/Scenario & \multirow{2}{*}{ Limit } & $\begin{array}{c}\text { Time of } \\
\text { Maximum }\end{array}$ & $\begin{array}{c}\text { Mean } \\
\text { (mSv) }\end{array}$ & $\begin{array}{c}\mathbf{9 5}^{\text {th }} \text { Percentile } \\
\text { (mSv) }\end{array}$ \\
\hline All-Pathways/Resident (Case 1) & \multirow{2}{*}{$0.25 \mathrm{mSv}$} & $1,000 \mathrm{y}$ & $8.1 \mathrm{E}-4$ & $2.7 \mathrm{E}-3$ \\
\cline { 1 - 2 } & & $1,000 \mathrm{y}$ & $8.7 \mathrm{E}-4$ & $3.0 \mathrm{E}-3$ \\
\hline All-Pathways/Resident (Case 2) & &
\end{tabular}

CEUSP key radionuclides are responsible for 25\% of the resident all-pathways annual TED at 1,000 y (Figure 4.4). The all-pathways resident TED is contributed predominantly by ${ }^{238} \mathrm{U}+\mathrm{P}$ (32\%), ${ }^{210} \mathrm{~Pb}+\mathrm{P}(22 \%),{ }^{229} \mathrm{Th}+\mathrm{P}(21 \%),{ }^{222} \mathrm{Rn}+\mathrm{P}(4 \%),{ }^{233} \mathrm{U}(4 \%),{ }^{228} \mathrm{Th}+\mathrm{P}(3 \%),{ }^{239} \mathrm{Pu}(3 \%)$, and ${ }^{234} \mathrm{U}(3 \%)$ at $1,000 \mathrm{y}$. From approximately 100 to $250 \mathrm{y}$, the CEUSP key radionuclide ${ }^{228} \mathrm{Th}+\mathrm{P}$ is the most important source of dose. Doses from CEUSP key radionuclides are not necessarily entirely from CEUSP waste as other sources of these radionuclides are present in the Area 5 RWMS inventory. 


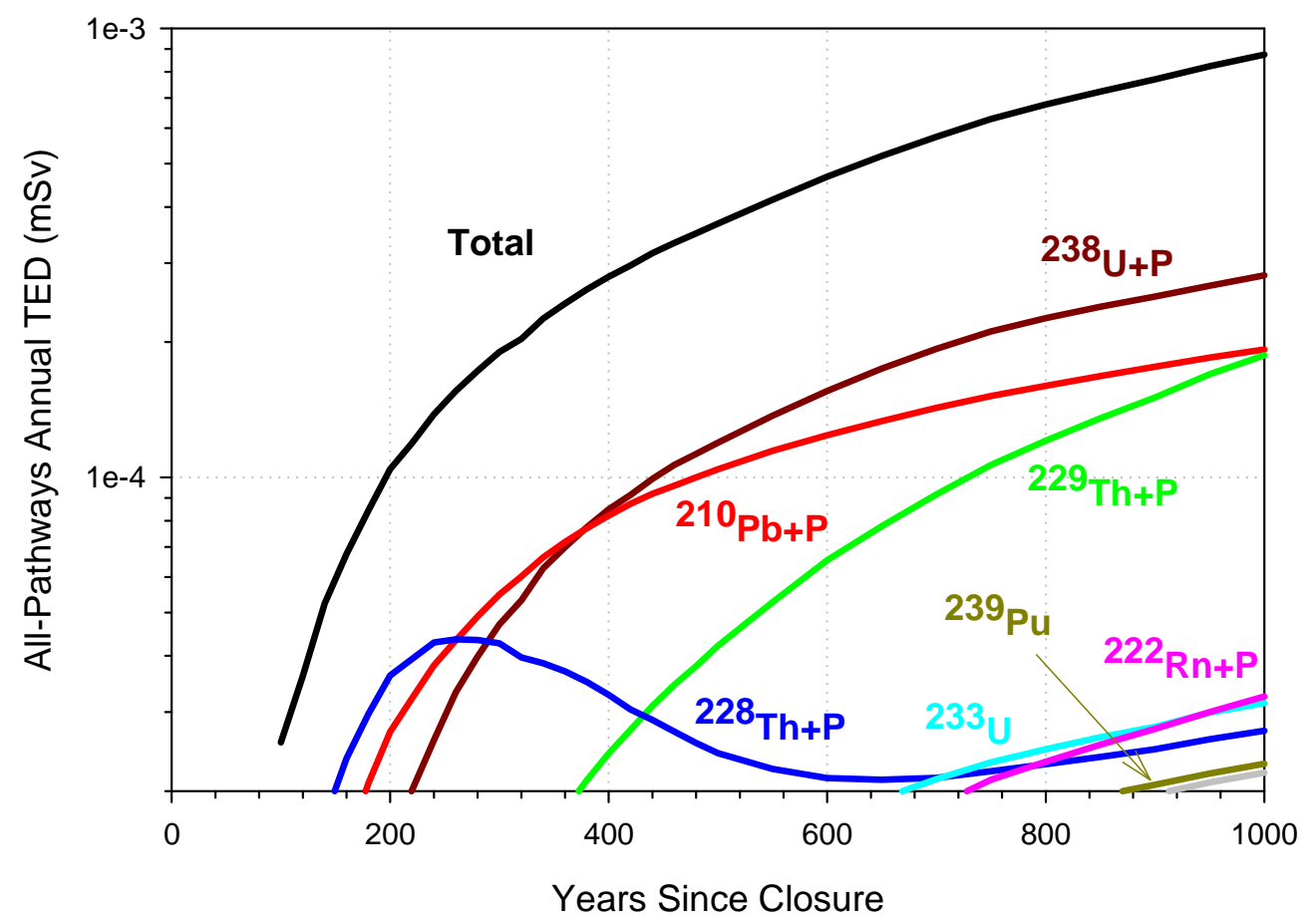

Figure 4.4 Resident all-pathway annual TED time history by radionuclide (Case 2)

\subsection{3 ${ }^{222}$ Rn Flux Density Results}

The ${ }^{222} \mathrm{Rn}$ flux density is averaged over the area of all post-1988 disposal units. The mean and $95^{\text {th }}$ percentile ${ }^{222} \mathrm{Rn}$ flux density is less than the 0.74 becquerel per square meter per second $\left(\mathrm{Bq} \mathrm{m} \mathrm{s}^{-2}\right.$ ) performance objective throughout the 1,000-y compliance period (Figure 4.5). A small fraction of the 5,000 realizations exceed the performance objective. Individual ${ }^{222} \mathrm{Rn}$ flux densities are relatively constant over the compliance period. The mean and $95^{\text {th }}$ percentile ${ }^{222} \mathrm{Rn}$ flux densities are increasing very slowly throughout the compliance period. 


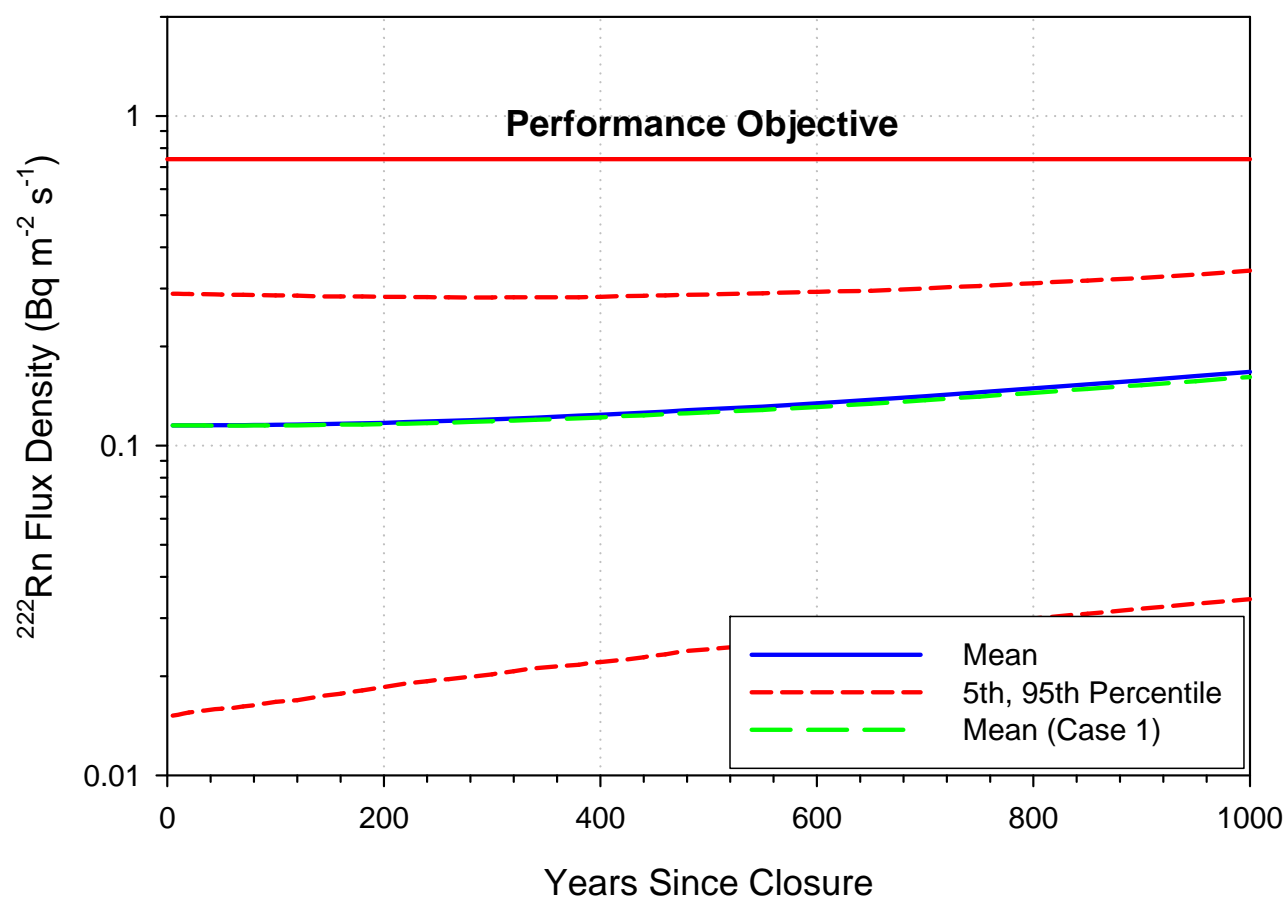

Figure $4.5^{222} \mathrm{Rn}$ flux density time history averaged over all disposal units (Case 2 unless otherwise noted)

The maximum mean ${ }^{222} \mathrm{Rn}$ flux density, $0.17 \mathrm{~Bq} \mathrm{~m}^{-2} \mathrm{~s}^{-1}$, occurs at $1,000 \mathrm{y}$ (Table 4.3). Addition of the CEUSP ${ }^{233} \mathrm{U}$ has minimal impact of the ${ }^{222} \mathrm{Rn}$ flux density.

Table 4.3 ${ }^{222}$ Rn flux density for the FY 2011 Area 5 RWMS Inventory with and without the CEUSP ${ }^{233} \mathrm{U}$ waste stream. Flux Density is averaged over all disposal units.

\begin{tabular}{|c|c|c|c|c|}
\hline Performance Objective & Limit & $\begin{array}{c}\text { Time of } \\
\text { Maximum }\end{array}$ & $\begin{array}{c}\text { Mean } \\
\left(\mathrm{Bq} \mathrm{m}^{-2} \mathrm{~s}^{-1}\right)\end{array}$ & $\begin{array}{c}95^{\text {th }} \text { Percentile } \\
\left(\mathrm{Bq} \mathrm{m}^{-2} \mathrm{~s}^{-1}\right)\end{array}$ \\
\hline Radon Flux Density (Case 1) & \multirow{2}{*}{$0.74 \mathrm{~Bq} \mathrm{~m}^{-2} \mathrm{~s}^{-1}$} & $1,000 \mathrm{y}$ & 0.16 & 0.33 \\
\hline Radon Flux Density (Case 2) & & $1,000 y$ & 0.17 & 0.34 \\
\hline
\end{tabular}

\subsubsection{Acute Intruder Scenarios Results}

Intruder results are evaluated for acute intruder scenarios only. NNSA/NSO IC policy is to maintain and enforce planned URs consistent with UGTA FFACO closure strategies (NNSA/NSO 2008). The Area 5 RWMS is within the proposed Frenchman Flat UGTA (CAU 98) groundwater use restriction area. The proposed land-use restrictions are assumed to eliminate the possibility of chronic intrusion for $1,000 \mathrm{y}$.

Among acute exposure scenarios, the acute drilling scenario is the only scenario considered plausible. The CEUSP waste depth of burial is planned to be below the depth of common construction excavations. Therefore, the acute construction scenario is not evaluated. 


\section{Acute Drilling Scenario}

The acute drilling scenario estimates the TED to a drill crew drilling a water well through a disposal unit. Exposure to contaminated drill cuttings occurs while augering a surface casing for the well.

All 5,000 realizations of the acute drilling scenario TED for the SLB disposal limits are less than the $5 \mathrm{mSv}$ performance measure (Figure 4.6). Individual time histories of TED decrease until $400 \mathrm{y}$, after which they remain relatively constant. Many individual realizations have a maximum at 100 to $200 \mathrm{y}$.

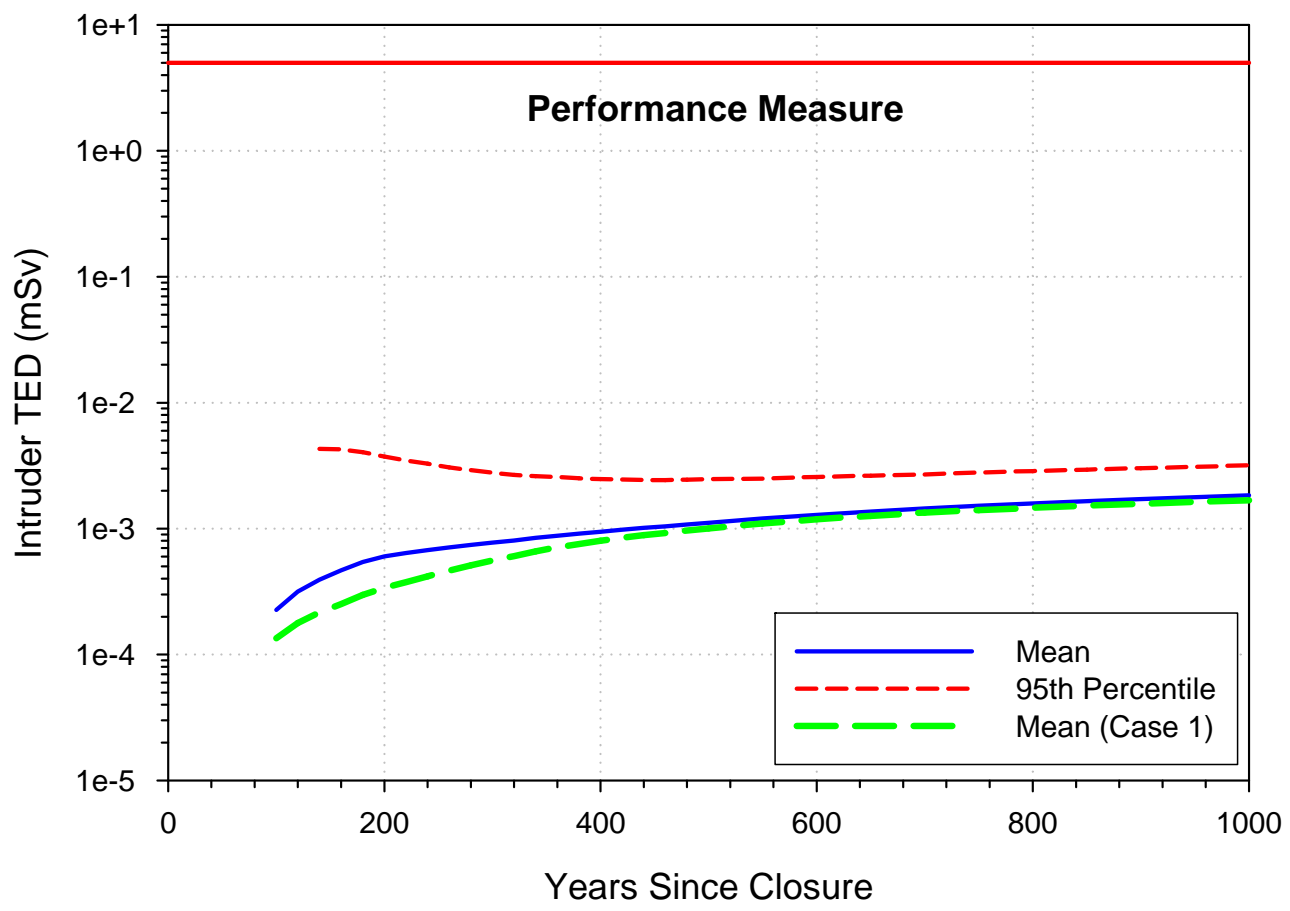

Figure 4.6 Acute intruder TED time history for the drilling intruder scenario at a SLB disposal unit (Case 2 unless otherwise noted)

The mean TED increases throughout the compliance period and reaches its maximum of $1.8 \mathrm{E}-3 \mathrm{mSv}$ at $1,000 \mathrm{y}$ (Table 4.4 ). The $95^{\text {th }}$ percentile initially decreases and has a maximum at the earliest time where there are enough realizations to calculate a value, or at about $140 \mathrm{y}$. The elevated uncertainty from 100 to 400 y reflects uncertainty about the TED contributed by short-lived radionuclides. Addition of the CEUSP ${ }^{233} \mathrm{U}$ waste increases the acute drilling dose $6 \%$ at $1,000 \mathrm{y}$, although the absolute value of the TED is only $0.04 \%$ of the $5 \mathrm{mSv}$ intruder performance measure. The relative increase is larger from 100 to $300 \mathrm{y}$ due to the effects of ${ }^{228} \mathrm{Th}+\mathrm{P}$, but the absolute value is much less than the $1,000-\mathrm{y}$ maximum. 
Table 4.4 Acute drilling TED for the FY 2011 Area 5 RWMS Inventory with and without the CEUSP ${ }^{233} \mathrm{U}$ waste stream (Case 2)

\begin{tabular}{|c|c|c|c|c|}
\hline Performance Objective & \multirow{2}{*}{ Limit } & $\begin{array}{c}\text { Time of } \\
\text { Maximum }\end{array}$ & $\begin{array}{c}\text { Mean } \\
\text { (mSv) }\end{array}$ & $\begin{array}{c}\mathbf{9 5}^{\text {th }} \text { Percentile } \\
\text { (mSv) }\end{array}$ \\
\hline Acute Drilling (All SLB) (Case 1) & \multirow{2}{*}{$5.0 \mathrm{mSv}$} & $1,000 \mathrm{y}$ & $1.7 \mathrm{E}-3$ & $2.9 \mathrm{E}-3$ \\
\cline { 1 - 3 } Acute Drilling (All SLB) (Case 2) & & $1,000 \mathrm{y}$ & $1.8 \mathrm{E}-3$ & $3.2 \mathrm{E}-3$ \\
\hline
\end{tabular}

The acute drilling intruder TED at $1,000 \mathrm{y}$ is due to predominantly ${ }^{238} \mathrm{U}+\mathrm{P}(31 \%),{ }^{229} \mathrm{Th}+\mathrm{P}$ (26\%), and ${ }^{222} \mathrm{Rn}+\mathrm{P}(18 \%)$ (Figure 4.7). For approximately 300 y after closure, the dose is due to predominantly ${ }^{228} \mathrm{Th}+\mathrm{P}$. The early peak in the ${ }^{228} \mathrm{Th}+\mathrm{P}$ dose indicates that the ${ }^{228} \mathrm{Th}$ is produced by decay of ${ }^{232} \mathrm{U}$ in ${ }^{233} \mathrm{U}$ waste streams. The ${ }^{228} \mathrm{Th}+\mathrm{P}$ dose is not entirely attributable to the CEUSP ${ }^{233} U$ waste stream as other sources of ${ }^{233} U$ have been disposed at the Area 5 RWMS.

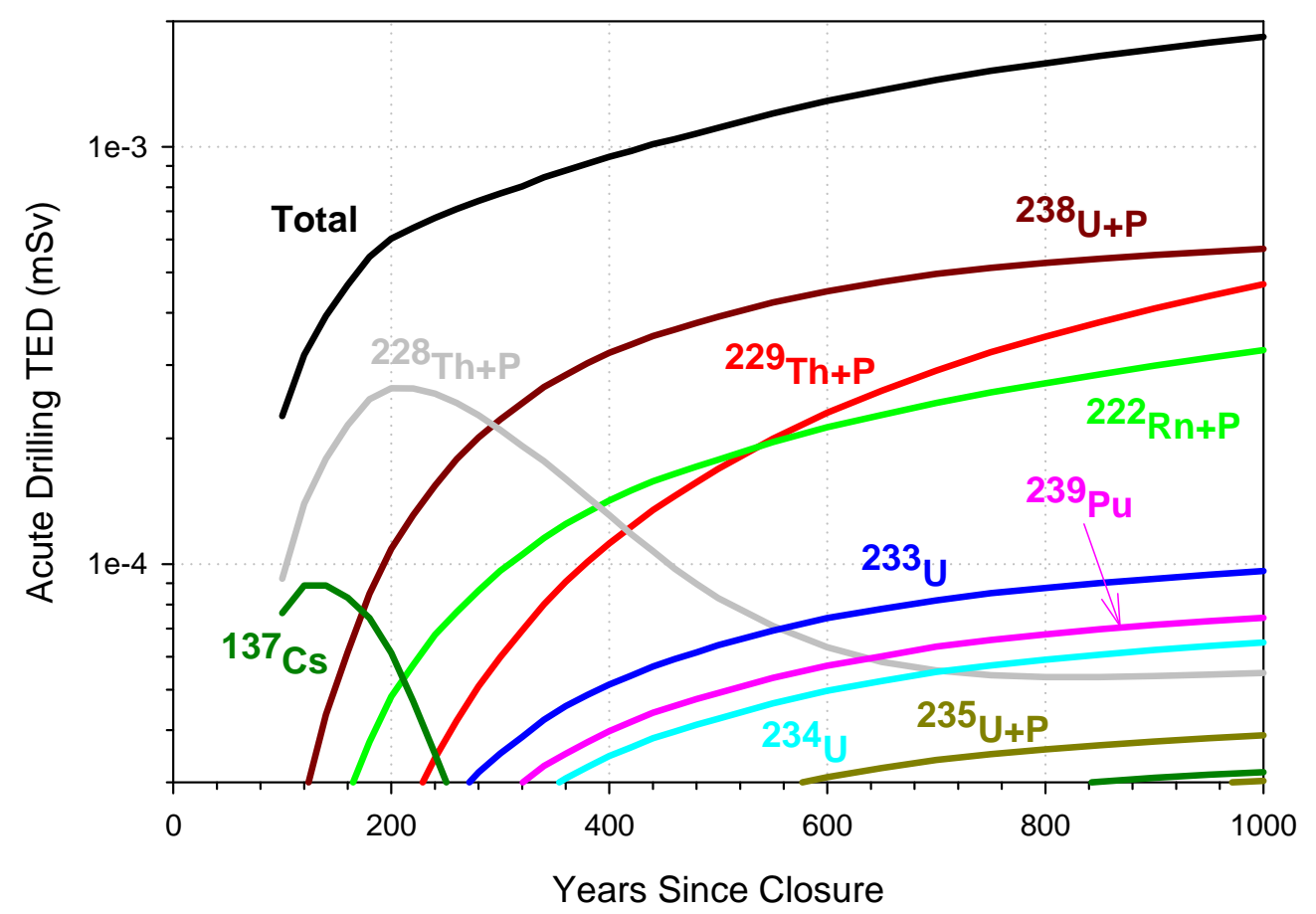

Figure 4.7 Acute drilling intruder TED time history by radionuclide (Case 2)

\subsection{Performance Assessment Uncertainty Analysis}

\subsubsection{Air Pathway Dose Uncertainty}

Uncertainty in the resident air pathway annual TED is evaluated at 1,000 y when the maximum dose is expected. The distribution of the air pathway annual TED for Case 2 at 1,000 y indicates that there is a high probability of compliance with the $0.1 \mathrm{mSv}$ performance objective (Figure 4.8). All 5,000 realizations are less than the performance objective. The log-transformed data are reasonably symmetric with a slight positive skew. The empirical cumulative distribution function (ecdf), the cumulative distribution of the simulated results, indicates that there is an 
$11 \%$ chance ICs will remain effective for more than 1,000 y and a high probability that doses are less than the performance objective at 1,000 $\mathrm{y}$.
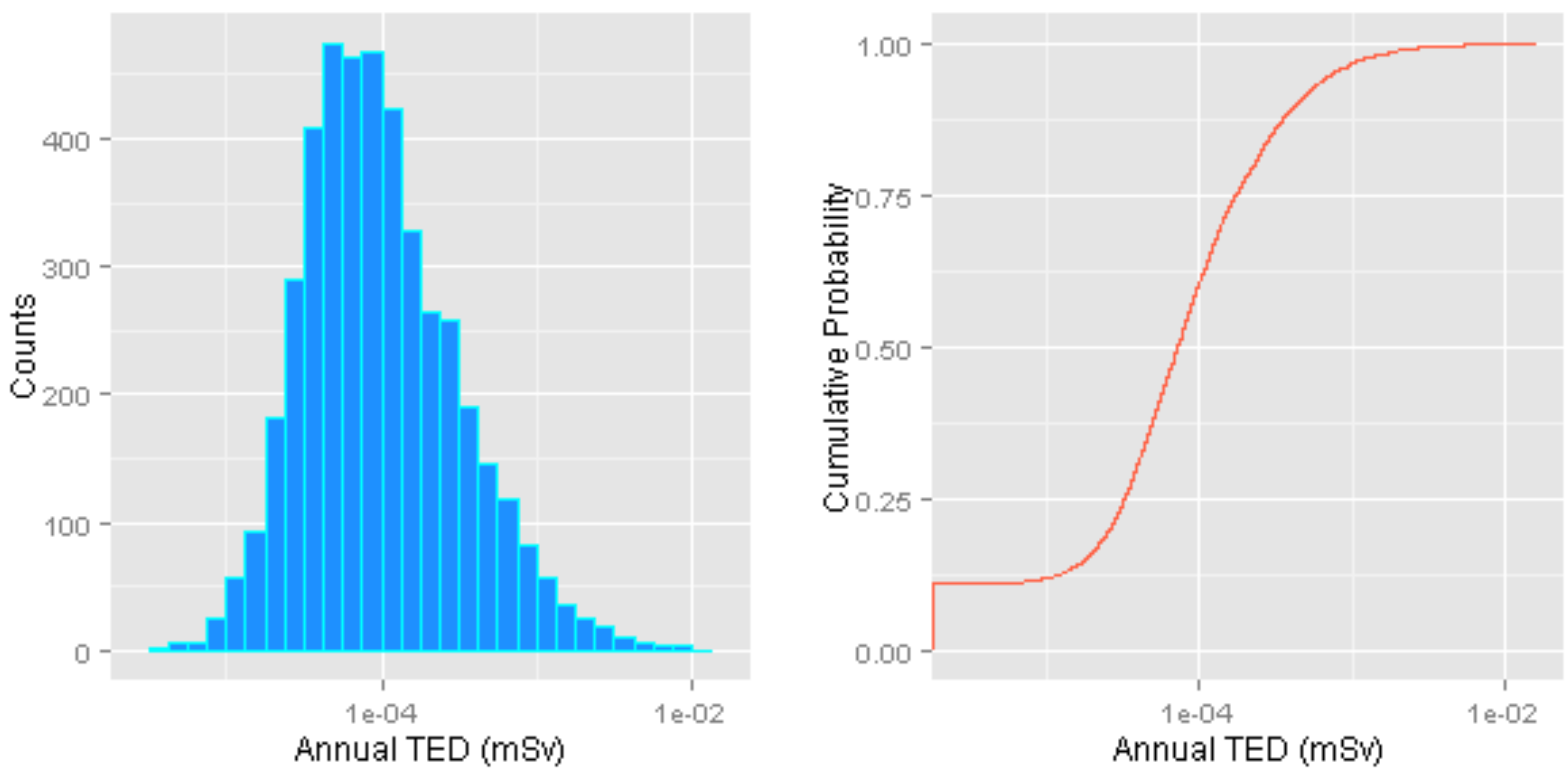

Figure 4.8 Histogram of non-zero values (left) and ecdf (right) of the resident air pathway annual TED at $1,000 \mathrm{y}$

\section{Alternative Scenarios}

Uncertainty contributed by the selected exposure scenario was evaluated by calculating air pathway TED for alternative scenarios. The scenarios evaluated are the transient occupancy scenario, the resident farmer scenario, and the open rangeland scenario for a ranch at the nearest NNSS boundary and at Cane Spring. The scenarios and their assumptions have been described previously (BN 2006a).

The means and $95^{\text {th }}$ percentiles of the additional scenarios are all less than the performance objective (Table 4.5). Although the exposure scenario is a source of uncertainty, there is a high likelihood of compliance for a range of reasonable scenarios.

Table 4.5 Alternative scenario air pathway TED for the FY 2011 Area 5 RWMS Inventory with the CEUSP ${ }^{233} U$ waste stream (Case 2)

\begin{tabular}{|c|c|c|c|c|}
\hline Performance Objective & Limit & $\begin{array}{c}\text { Time of } \\
\text { Maximum }\end{array}$ & $\begin{array}{c}\text { Mean } \\
\text { (mSv) }\end{array}$ & $\begin{array}{c}\mathbf{9 5}^{\text {th }} \text { Percentile } \\
\text { (mSv) }\end{array}$ \\
\hline Air Pathway/Transient Occupancy & $0.1 \mathrm{mSv}$ & $1,000 \mathrm{y}$ & $1.0 \mathrm{E}-4$ & $3.8 \mathrm{E}-4$ \\
\hline Air Pathway/Resident Farmer & $0.1 \mathrm{mSv}$ & $1,000 \mathrm{y}$ & $5.5 \mathrm{E}-4$ & $2.0 \mathrm{E}-3$ \\
\hline Air Pathway/Cane Spring & $0.1 \mathrm{mSv}$ & $1,000 \mathrm{y}$ & $5.4 \mathrm{E}-9$ & $1.6 \mathrm{E}-8$ \\
\hline Air Pathway/NNSS Boundary & $0.1 \mathrm{mSv}$ & $1,000 \mathrm{y}$ & $9.1 \mathrm{E}-8$ & $2.6 \mathrm{E}-7$ \\
\hline
\end{tabular}


The resident farmer and transient occupancy scenarios have the highest air pathway TED (Figure 4.9). The air pathway open rangeland scenario TEDs are much less than the other scenarios.

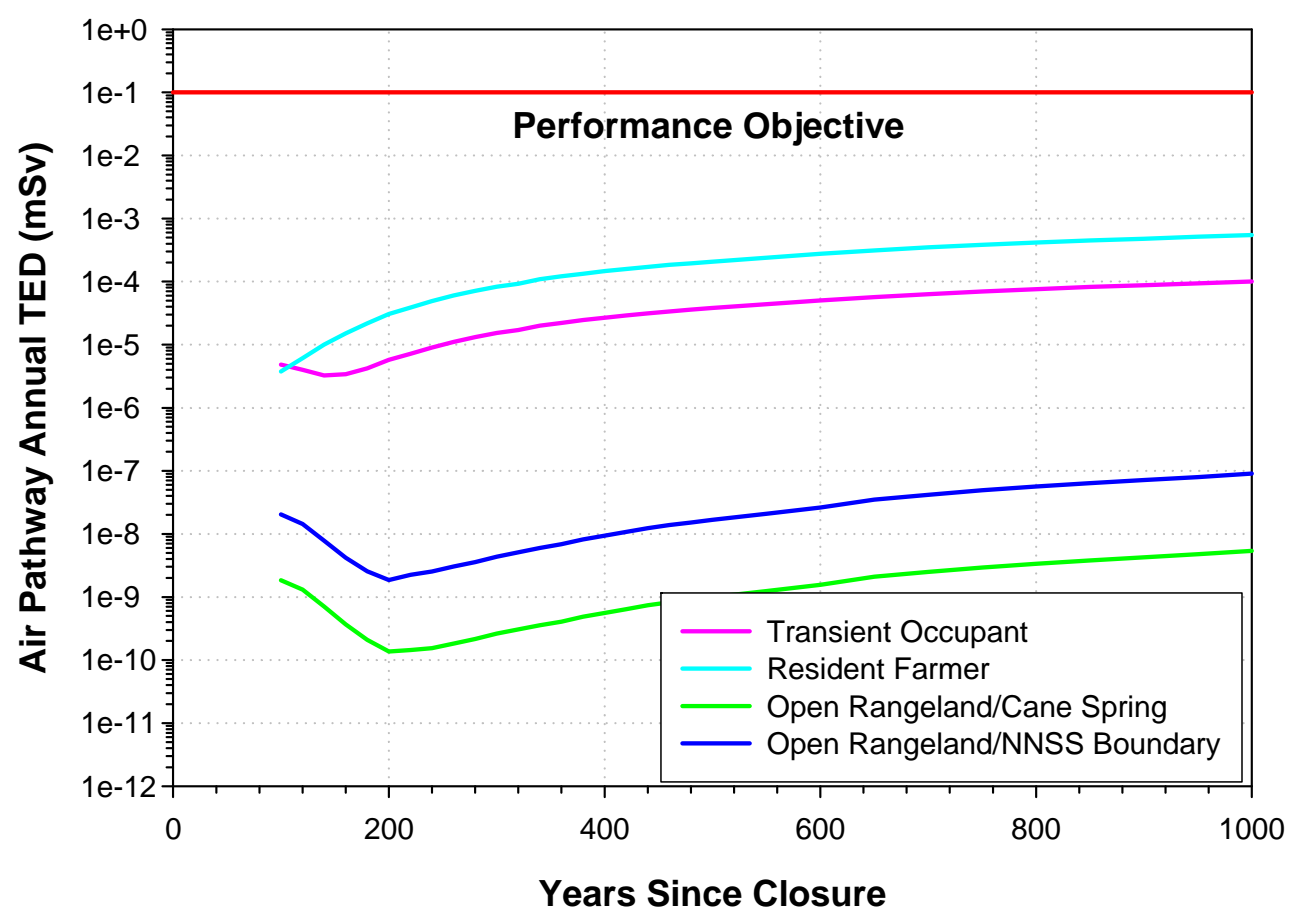

Figure 4.9 Air pathway annual TED time histories for alternative scenarios (Case 2)

\subsubsection{All-Pathways Dose Uncertainty}

Uncertainty in the resident all-pathways annual TED is evaluated at 1,000 y when the maximum dose is expected. The distribution of the all-pathways annual TED for Case 2 at 1,000 y indicates that there is a high probability of compliance with the $0.25 \mathrm{mSv}$ performance objective (Figure 4.10). All 5,000 realizations are less than the performance objective. The log-transformed data are reasonably symmetric with a slight positive skew. The ecdf indicates that there is an $11 \%$ chance of ICs remaining effective for more than 1,000 y and a high probability that the TED is less than $0.25 \mathrm{mSv}$. 

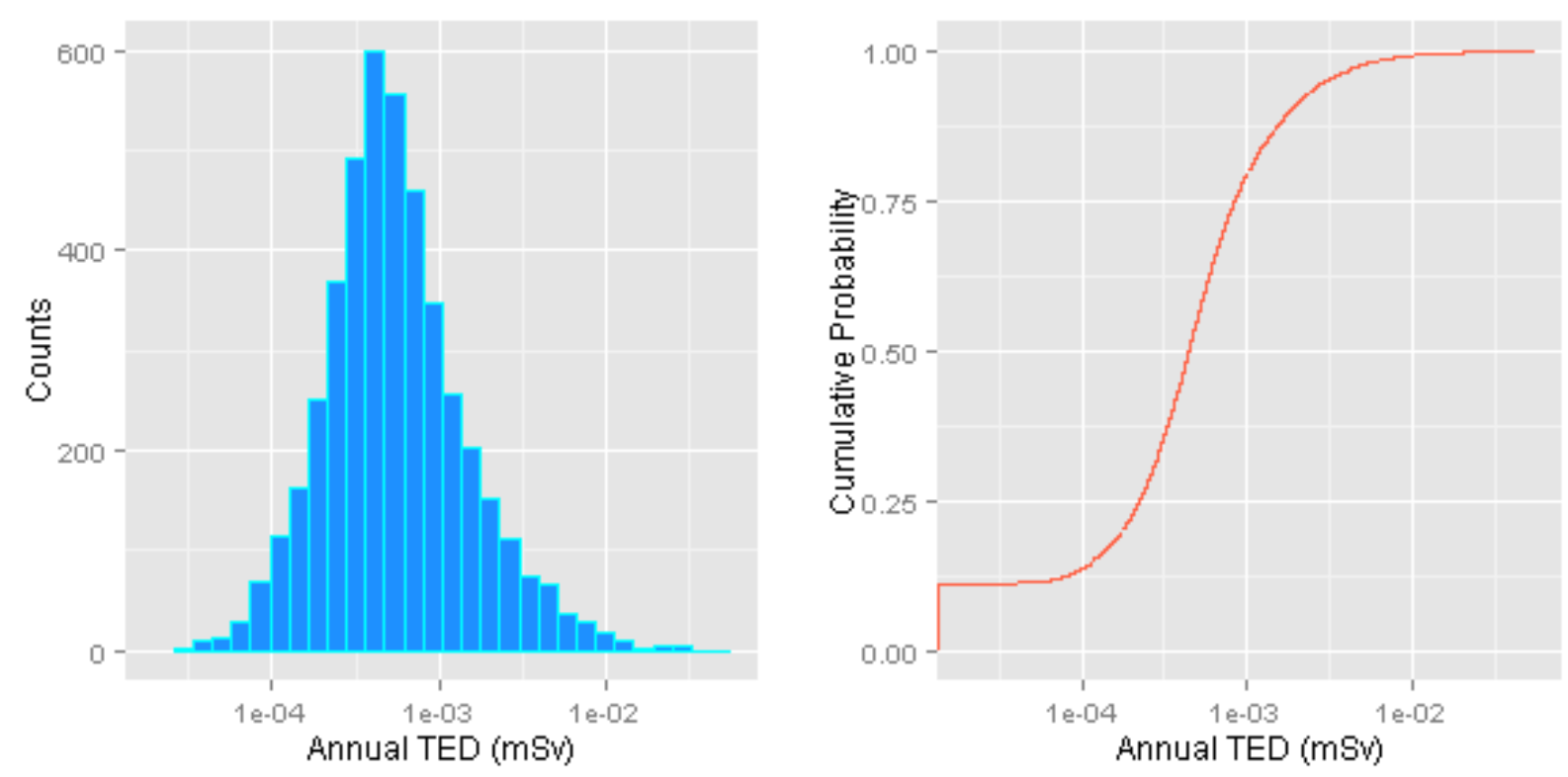

Figure 4.10 Histogram of non-zero values (left) and ecdf (right) of the resident all-pathways annual TED at $1,000 \mathrm{y}$

\section{Alternative Scenarios}

Uncertainty contributed by the selected exposure scenario was evaluated by calculating the all-pathways annual TED for alternative scenarios. The scenarios evaluated are the transient occupancy scenario, the resident farmer scenario, and the open rangeland scenario for a ranch at the nearest NNSS boundary and at Cane Spring. The scenarios and their assumptions have been described previously (BN 2006a).

The means and $95^{\text {th }}$ percentiles of the alternative scenarios are all less than the performance objective (Table 4.6). Although the scenario selected is a source of uncertainty, there is a high likelihood of compliance for a range of reasonable scenarios.

Table 4.6 Alternative scenario all-pathways TED for the FY 2011 Area 5 RWMS Inventory with the CEUSP ${ }^{233} U$ waste stream (Case 2)

\begin{tabular}{|c|c|c|c|c|}
\hline Performance Objective/Scenario & Limit & $\begin{array}{c}\text { Time of } \\
\text { Maximum }\end{array}$ & $\begin{array}{c}\text { Mean } \\
\text { (mSv) }\end{array}$ & $\begin{array}{c}\mathbf{9 5}^{\text {th }} \text { Percentile } \\
\text { (mSv) }\end{array}$ \\
\hline All-Pathway/Transient Occupancy & $0.25 \mathrm{mSv}$ & $1,000 \mathrm{y}$ & $5.0 \mathrm{E}-3$ & $1.1 \mathrm{E}-2$ \\
\hline All-Pathway/Resident Farmer & $0.25 \mathrm{mSv}$ & $1,000 \mathrm{y}$ & $2.0 \mathrm{E}-2$ & $6.6 \mathrm{E}-2$ \\
\hline All-Pathway/Cane Spring & $0.25 \mathrm{mSv}$ & $1,000 \mathrm{y}$ & $1.7 \mathrm{E}-3$ & $6.1 \mathrm{E}-3$ \\
\hline All-Pathway/NNSS Boundary & $0.25 \mathrm{mSv}$ & $1,000 \mathrm{y}$ & $1.9 \mathrm{E}-3$ & $7.0 \mathrm{E}-3$ \\
\hline
\end{tabular}

The resident farmer has the highest all-pathways annual TED over the 1,000-y compliance period (Figure 4.11). The all-pathways open rangeland scenario TEDs initially exceed the transient occupancy dose but are less than all other scenarios by $150 \mathrm{y}$. The higher doses before $150 \mathrm{y}$ are due to ingestion of ${ }^{3} \mathrm{H}$ in beef and milk produced by cattle grazing at the Area 5 RWMS. 


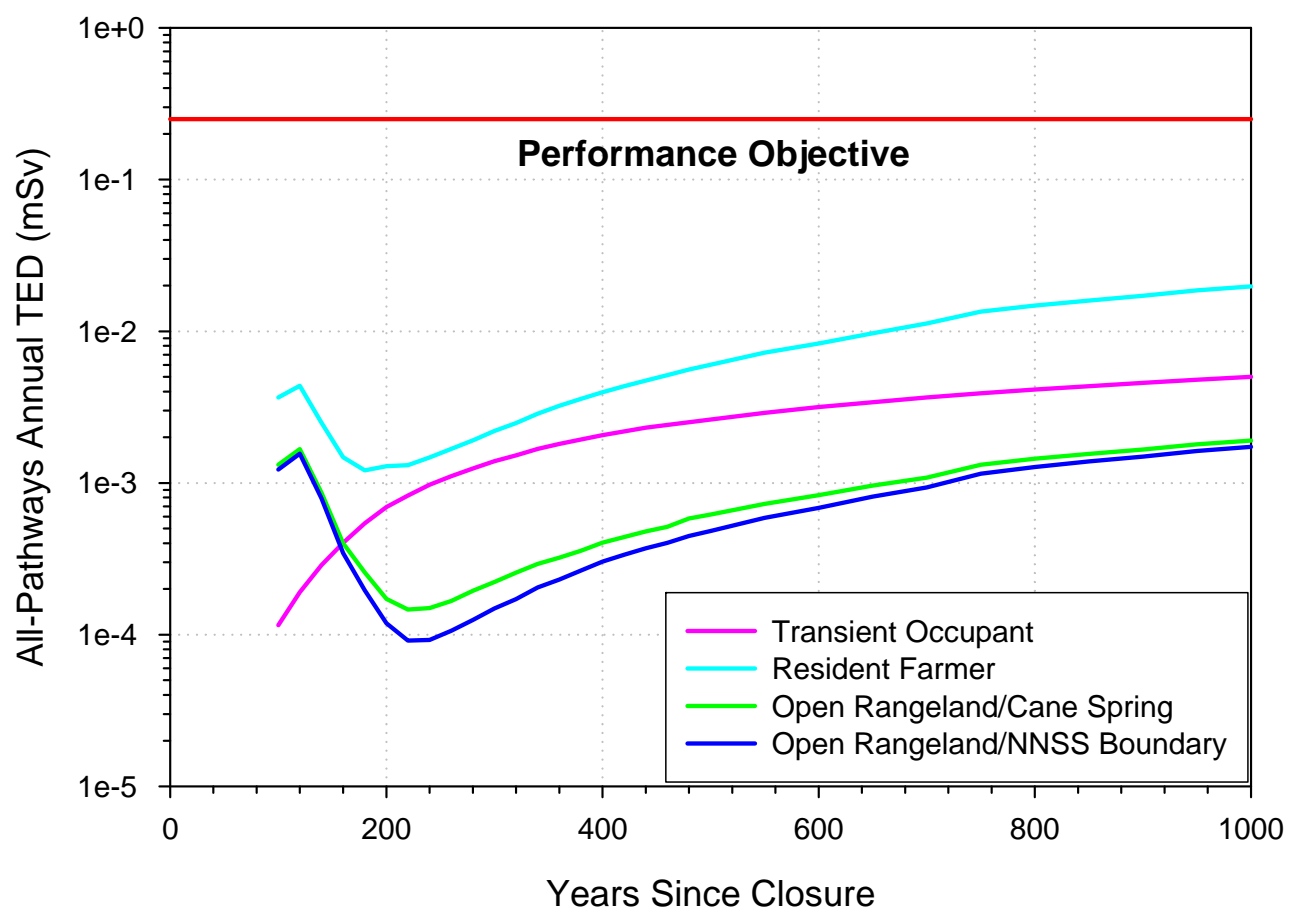

Figure 4.11 All-pathways annual TED time histories for alternative scenarios (Case 2)

\subsection{3 ${ }^{222}$ Rn Flux Density Uncertainty}

Uncertainty in the ${ }^{222} \mathrm{Rn}$ flux density is evaluated at 1,000 y when the maximum flux is expected. The distribution of the ${ }^{222} \mathrm{Rn}$ flux density for Case 2 at $1,000 \mathrm{y}$ indicates that there is a high probability of compliance with the $0.74 \mathrm{~Bq} \mathrm{~m}^{-2} \mathrm{~s}^{-1}$ performance objective (Figure 4.12). The logtransformed data are negatively skewed. The ecdf indicates that there is a 2 in 5,000 chance of exceeding the performance objective or greater than a $99.9 \%$ probability of compliance at $1,000 \mathrm{y}$. 

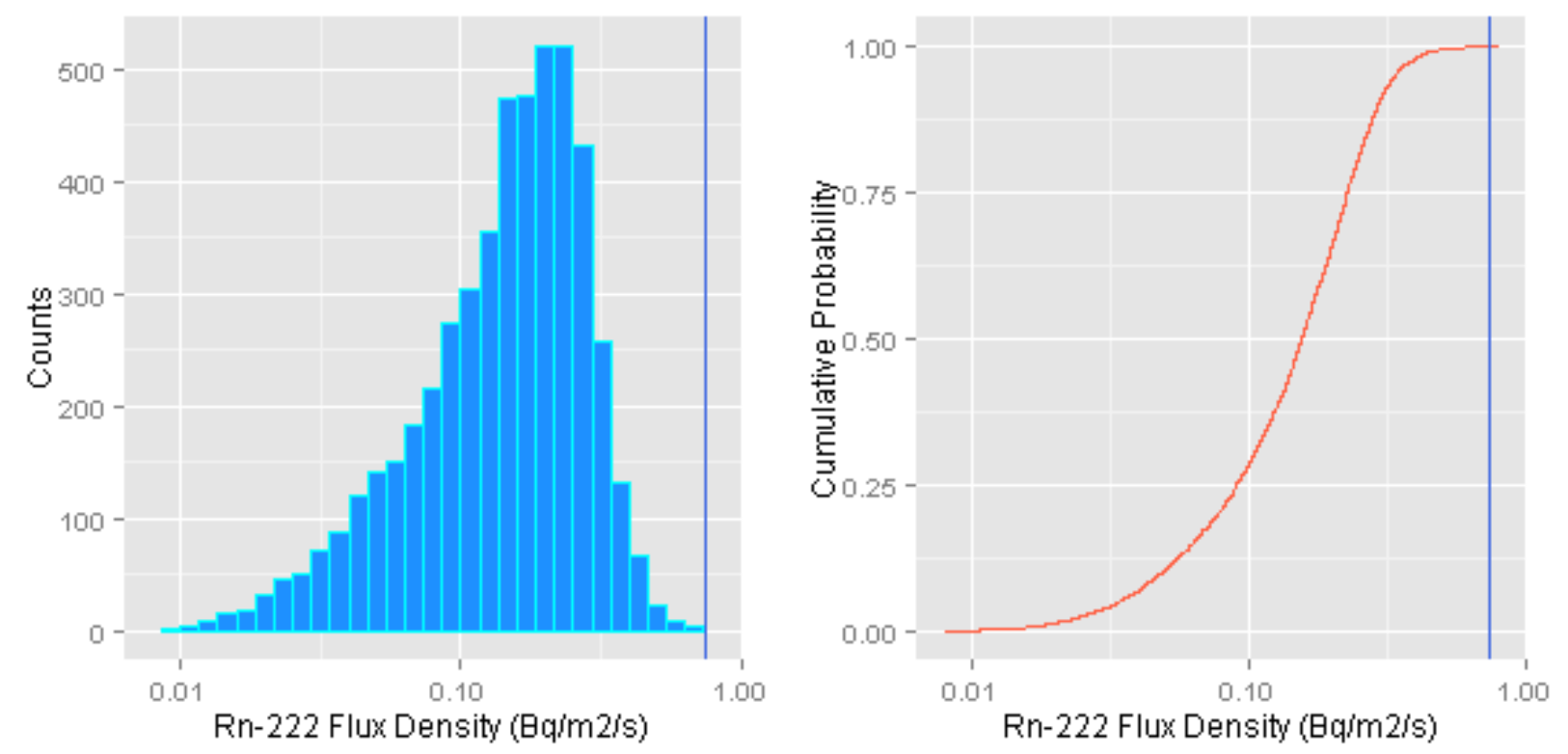

Figure 4.12 Histogram (left) and ecdf (right) of the ${ }^{222} \mathrm{Rn}$ flux density averaged over the Area 5 RWMS at 1,000 y. Performance objective shown in blue. 
This Page Intentionally Left Blank 


\subsection{Tier II: Assessing Long-Term Acceptability for Near-Surface Disposal}

The purpose of the tier II analyses is to assess the long-term acceptability of the CEUSP ${ }^{233} \mathrm{U}$ for near surface disposal at the Area 5 RWMS. The uniqueness of the CEUSP ${ }^{233} U$ waste and its radiological properties raise potential concerns about its acceptability for near-surface disposal as LLW. The tier II analyses assess the long-term performance of the waste and impacts of container degradation and depth of burial. Chapter 2 describes site characteristics, engineered barriers, and administrative controls that enhance long-term site stability and security.

\subsection{Long-Term Performance}

\subsubsection{Air Pathway Long-Term Performance}

The long-term performance of the CEUSP waste stream was evaluated by increasing the model duration to 10,000 y. The air pathway annual TED peak dose occurs at 10,000 $\mathrm{y}$ for all scenarios (Table 5.1). The mean and $95^{\text {th }}$ percentile annual TEDs are less than the $0.1 \mathrm{mSv}$ performance objective for all scenarios.

Table 5.1 Long-term air pathway results for the CEUSP ${ }^{233} \mathrm{U}$ waste stream averaged over the waste disposed through FY 2011 (Case 2)

\begin{tabular}{|c|c|c|c|c|}
\hline Performance Objective & $\begin{array}{c}\text { 1,000-y Limit } \\
(\mathrm{mSv})\end{array}$ & $\begin{array}{c}\text { Time of } \\
\text { Maximum }\end{array}$ & $\begin{array}{l}\text { Mean } \\
(\mathrm{mSv})\end{array}$ & $\begin{array}{c}95^{\text {th }} \text { Percentile } \\
\text { (mSv) }\end{array}$ \\
\hline Air Pathway/Transient Occupancy & \multirow{5}{*}{0.1} & $10,000 y$ & $1.5 \mathrm{E}-3$ & $5.9 \mathrm{E}-3$ \\
\hline Air Pathway/Resident & & 10,000 y & $3.0 \mathrm{E}-3$ & $1.1 \mathrm{E}-2$ \\
\hline Air Pathway/Resident Farmer & & $10,000 \mathrm{y}$ & $8.5 E-3$ & 3.0E-2 \\
\hline Air Pathway/Cane Spring & & 10,000 y & $5.4 \mathrm{E}-7$ & $1.8 \mathrm{E}-6$ \\
\hline Air Pathway/NNSS Boundary & & $10,000 \mathrm{y}$ & $9.0 \mathrm{E}-6$ & $3.0 \mathrm{E}-5$ \\
\hline
\end{tabular}

The mean resident air pathway annual TED continues to increase slowly beyond the 1,000-y compliance period (Figure 5.1). The mean resident air pathway annual TED is a small fraction of the performance objective throughout the 10,000-y period. The maximum resident air pathway TED is $3 \%$ of the performance objective. Over $99.9 \%$ of the realizations are less than $0.1 \mathrm{mSv}$ at $10,000 \mathrm{y}$. It is likely that the air pathway resident TED will remain less than $0.1 \mathrm{mSv}$ for a substantial period beyond the 1,000-y compliance period. 


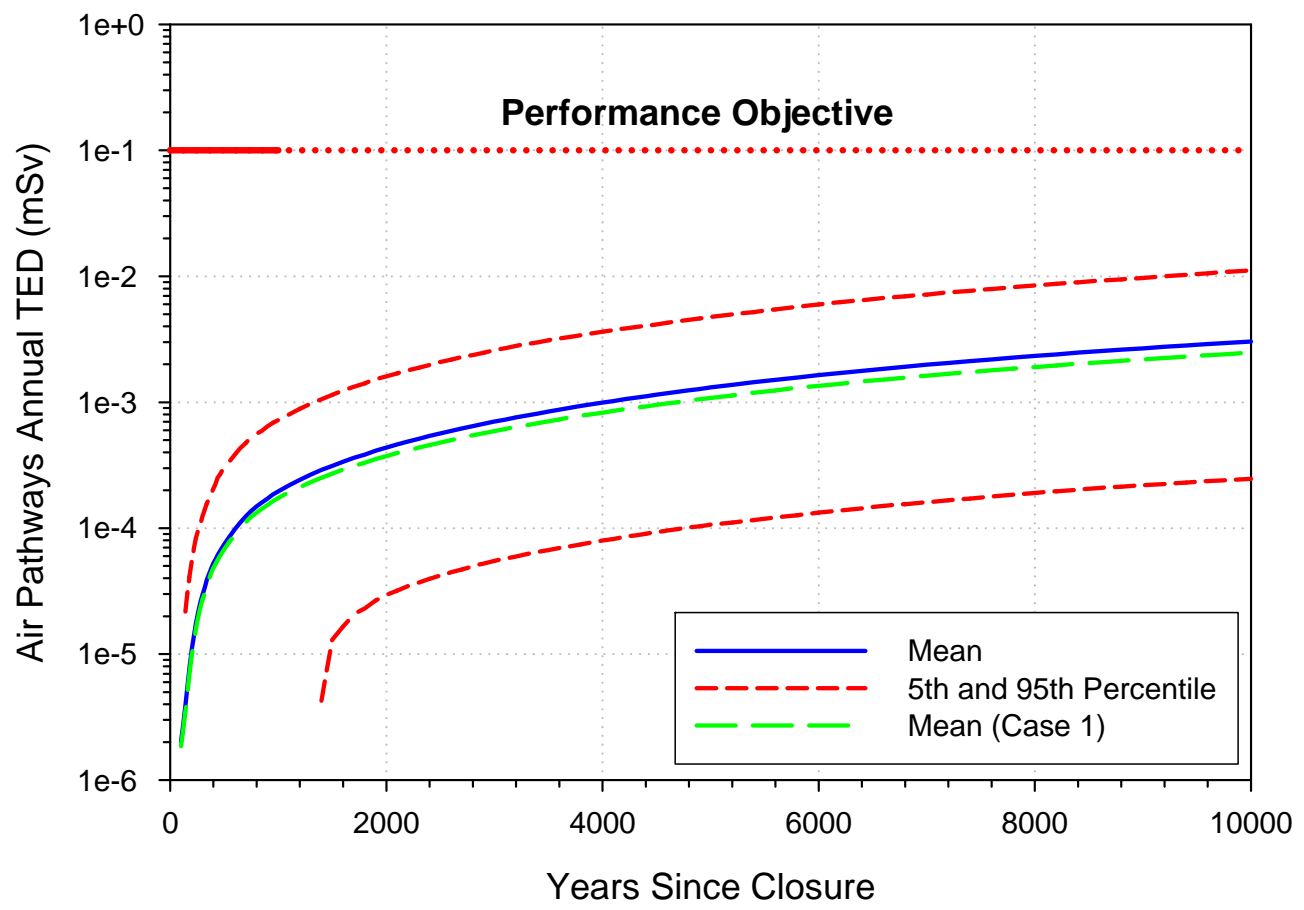

Figure 5.1 Resident air pathway annual TED time history over 10,000 y (Case 2 unless otherwise noted)

The effects of the CESUP waste stream can be assessed by comparing results with and without the waste stream. Disposal of the CEUSP waste stream increases the air pathway doses (Table 5.2). The mean resident air pathway annual TED increases approximately $20 \%$ at $10,000 \mathrm{y}$ with the addition of the CEUSP ${ }^{233} \mathrm{U}$ waste stream, but the absolute value is a small fraction of the performance objective.

Table 5.2 Long-term air pathway results for the waste disposed through FY 2011 (Case 1)

\begin{tabular}{|c|c|c|c|c|}
\hline Performance Objective & $\begin{array}{c}\mathbf{1 , 0 0 0}-\mathbf{y} \text { Limit } \\
(\mathbf{m S v})\end{array}$ & $\begin{array}{c}\text { Time of } \\
\text { Maximum }\end{array}$ & $\begin{array}{c}\text { Mean } \\
\mathbf{( m S v )}\end{array}$ & $\begin{array}{c}\mathbf{9 5}^{\text {th }} \text { Percentile } \\
\text { (mSv) }\end{array}$ \\
\hline Air Pathway/Transient Occupancy & 0.1 & $10,000 \mathrm{y}$ & $1.3 \mathrm{E}-3$ & $4.7 \mathrm{E}-3$ \\
\hline Air Pathway/Resident & 0.1 & $10,000 \mathrm{y}$ & $2.5 \mathrm{E}-3$ & $8.8 \mathrm{E}-3$ \\
\hline Air Pathway/Resident Farmer & 0.1 & $10,000 \mathrm{y}$ & $6.9 \mathrm{E}-3$ & $2.4 \mathrm{E}-2$ \\
\hline Air Pathway/Cane Spring & 0.1 & $10,000 \mathrm{y}$ & $4.3 \mathrm{E}-7$ & $1.4 \mathrm{E}-6$ \\
\hline Air Pathway/NNSS Boundary & 0.1 & $10,000 \mathrm{y}$ & $7.1 \mathrm{E}-6$ & $2.4 \mathrm{E}-5$ \\
\hline
\end{tabular}

\subsubsection{All-Pathways Long-Term Performance}

The duration of the all-pathways analysis was increased to $10,000 \mathrm{y}$ to assess performance beyond the 1,000-y compliance period. The all-pathway annual TED peak dose occurs at $10,000 \mathrm{y}$ for all scenarios (Table 5.3). The mean annual TEDs are less than the $0.25 \mathrm{mSv}$ performance objective for all scenarios. The $95^{\text {th }}$ percentile annual TEDS are less than the performance objective for all scenarios, except for the resident farmer scenario. The resident 
farmer scenario mean all-pathways TED is a significant fraction of the $0.25 \mathrm{mSv}$ performance objective and the $95^{\text {th }}$ percentile exceeds the performance objective at 10,000 $\mathrm{y}$.

Table 5.3 Long-term all-pathways results for the CEUSP ${ }^{233} \mathrm{U}$ waste stream averaged over the waste disposed through FY 2011 (Case 2)

\begin{tabular}{|c|c|c|c|c|}
\hline Performance Objective & $\begin{array}{c}\mathbf{1 , 0 0 0}-\mathbf{y} \text { Limit } \\
\text { (mSv) }\end{array}$ & $\begin{array}{c}\text { Time of } \\
\text { Maximum }\end{array}$ & $\begin{array}{c}\text { Mean } \\
\text { (mSv) }\end{array}$ & $\begin{array}{c}\mathbf{9 5}^{\text {th }} \text { Percentile } \\
\text { (mSv) }\end{array}$ \\
\hline All-Pathways/Transient Occupancy & 0.25 & $10,000 \mathrm{y}$ & $7.7 \mathrm{E}-2$ & $1.6 \mathrm{E}-1$ \\
\hline All-Pathways/Resident & 0.25 & $10,000 \mathrm{y}$ & $1.5 \mathrm{E}-2$ & $4.8 \mathrm{E}-2$ \\
\hline All-Pathways/Resident Farmer & 0.25 & $10,000 \mathrm{y}$ & $2.3 \mathrm{E}-1$ & $7.3 \mathrm{E}-1$ \\
\hline All-Pathways/Cane Spring & 0.25 & $10,000 \mathrm{y}$ & $2.0 \mathrm{E}-2$ & $6.2 \mathrm{E}-2$ \\
\hline All-Pathways/NNSS Boundary & 0.25 & $10,000 \mathrm{y}$ & $2.0 \mathrm{E}-2$ & $6.3 \mathrm{E}-2$ \\
\hline
\end{tabular}

The mean resident all-pathways annual TED continues to increase slowly beyond the $1,000-y$ compliance period (Figure 5.2). The mean resident air pathway annual TED is a small fraction (6\%) of the performance objective throughout the 10,000 y period. A few realizations begin to exceed the $0.25 \mathrm{mSv}$ level beyond 4,000 y. At 10,000 y, 99.7\% of the realizations are less than the $0.25 \mathrm{mSv}$ performance objective. It appears likely that the all-pathways resident annual TED will remain less than $0.25 \mathrm{mSv}$ for a substantial period beyond the 1,000-y compliance period.

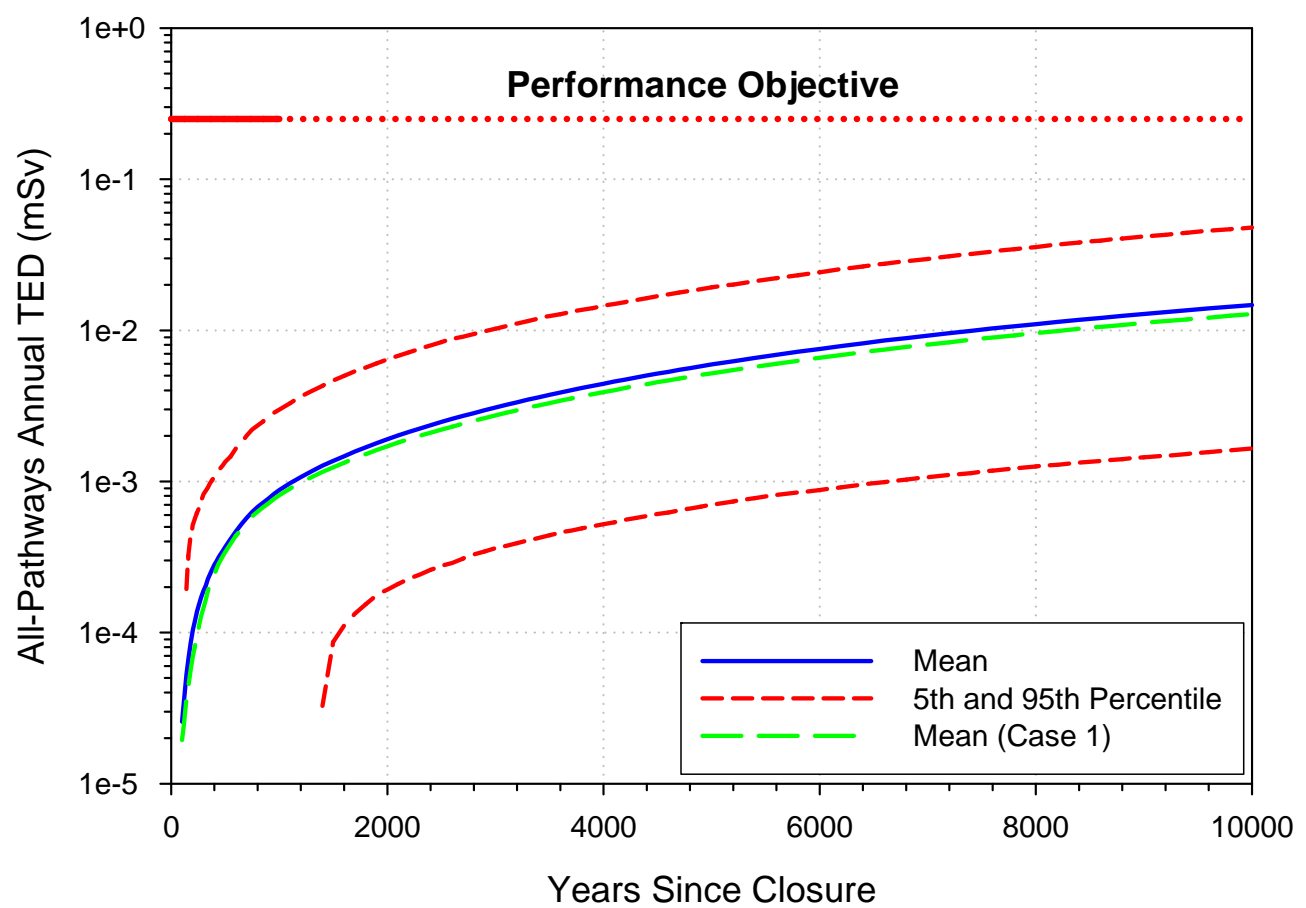

Figure 5.2 Resident all-pathways annual TED time history over 10,000 y (Case 2 unless otherwise noted)

The effects of the CESUP waste stream can be assessed by comparing results with and without the waste stream. Disposal of the CEUSP waste stream increases the all-pathways dose for the transient occupancy and resident scenarios (Table 5.4). The mean resident all-pathways annual 
TED increases approximately $15 \%$ at $10,000 \mathrm{y}$, but remains only $6 \%$ of the performance objective. The other scenarios are unaffected by the addition of CEUSP waste stream. The resident farmer $95^{\text {th }}$ percentile all-pathways TED without the CEUSP waste stream also exceeds the performance objective at 10,000 y. The resident farmer scenario is a highly unlikely exposure scenario for an arid site such as the Area 5 RWMS.

Table 5.4 Long-term all-pathways results for the waste disposed through FY 2011 (Case 1)

\begin{tabular}{|c|c|c|c|c|}
\hline Performance Objective & $\begin{array}{c}\mathbf{1 , 0 0 0}-\mathbf{y} \text { Limit } \\
\text { (mSv) }\end{array}$ & $\begin{array}{c}\text { Time of } \\
\text { Maximum }\end{array}$ & $\begin{array}{c}\text { Mean } \\
\text { (mSv) }\end{array}$ & $\begin{array}{c}\mathbf{9 5}^{\text {th }} \text { Percentile } \\
\text { (mSv) }\end{array}$ \\
\hline All-Pathways/Transient Occupancy & 0.25 & $10,000 \mathrm{y}$ & $7.3 \mathrm{E}-2$ & $1.5 \mathrm{E}-1$ \\
\hline All-Pathways/Resident & 0.25 & $10,000 \mathrm{y}$ & $1.3 \mathrm{E}-2$ & $4.1 \mathrm{E}-2$ \\
\hline All-Pathways/Resident Farmer & 0.25 & $10,000 \mathrm{y}$ & $2.3 \mathrm{E}-1$ & $7.1 \mathrm{E}-1$ \\
\hline All-Pathways/Cane Spring & 0.25 & $10,000 \mathrm{y}$ & $2.0 \mathrm{E}-2$ & $6.2 \mathrm{E}-2$ \\
\hline All-Pathways/NNSS Boundary & 0.25 & $10,000 \mathrm{y}$ & $2.0 \mathrm{E}-2$ & $6.3 \mathrm{E}-2$ \\
\hline
\end{tabular}

\subsubsection{Peak CEUSP Waste Stream All-Pathways Dose}

The duration of model simulations was extended beyond 10,000 y to determine when the peak dose from the CEUSP waste stream key radionuclides occurs. The CEUSP waste key radionuclides are those nuclides that are the major contributors to dose. Key radionuclides have high environmental mobility, large radionuclide dose conversion factors, and/or high concentrations in the waste stream. The CEUSP waste stream key radionuclides are ${ }^{228} \mathrm{Th},{ }^{229} \mathrm{Th}$, ${ }^{232} \mathrm{U}$, and ${ }^{233} \mathrm{U}$.

The peak dose from ${ }^{228} \mathrm{Th}+\mathrm{P}$ occurs a few hundred years after closure and is accounted for in the 1,000-y analyses. The ${ }^{233} \mathrm{U}$ decay chain does not reach a peak inventory activity until 29,000 y when ${ }^{229} \mathrm{Th}$ reaches secular equilibrium with ${ }^{233} \mathrm{U}$. The peak dose from the ${ }^{233} \mathrm{U}$ decay chain is expected to occur beyond 29,000 y due to delays caused by environmental transport to the accessible environment.

The peak CEUSP dose was evaluated by increasing the model duration to 60,000 y. Examination of the resident all-pathways annual TED indicates that the peak ${ }^{233} \mathrm{U}$ dose occurs at 40,000 y and the peak ${ }^{229} \mathrm{Th}+\mathrm{P}$ dose occurs at 48,000 y (Figure 5.3). The resident all-pathways annual TED is $0.03 \mathrm{mSv}$ at 48,000 y. At the peak ${ }^{229} \mathrm{Th}+\mathrm{P}$ dose, CEUSP waste stream key radionuclides contribute approximately $12 \%$ of the resident all-pathway annual TED. Not all of the CEUSP waste stream key radionuclide dose can be attributed to the CEUSP waste stream as the Area 5 RWMS inventory already includes ${ }^{233} \mathrm{U}$ disposed previously. 


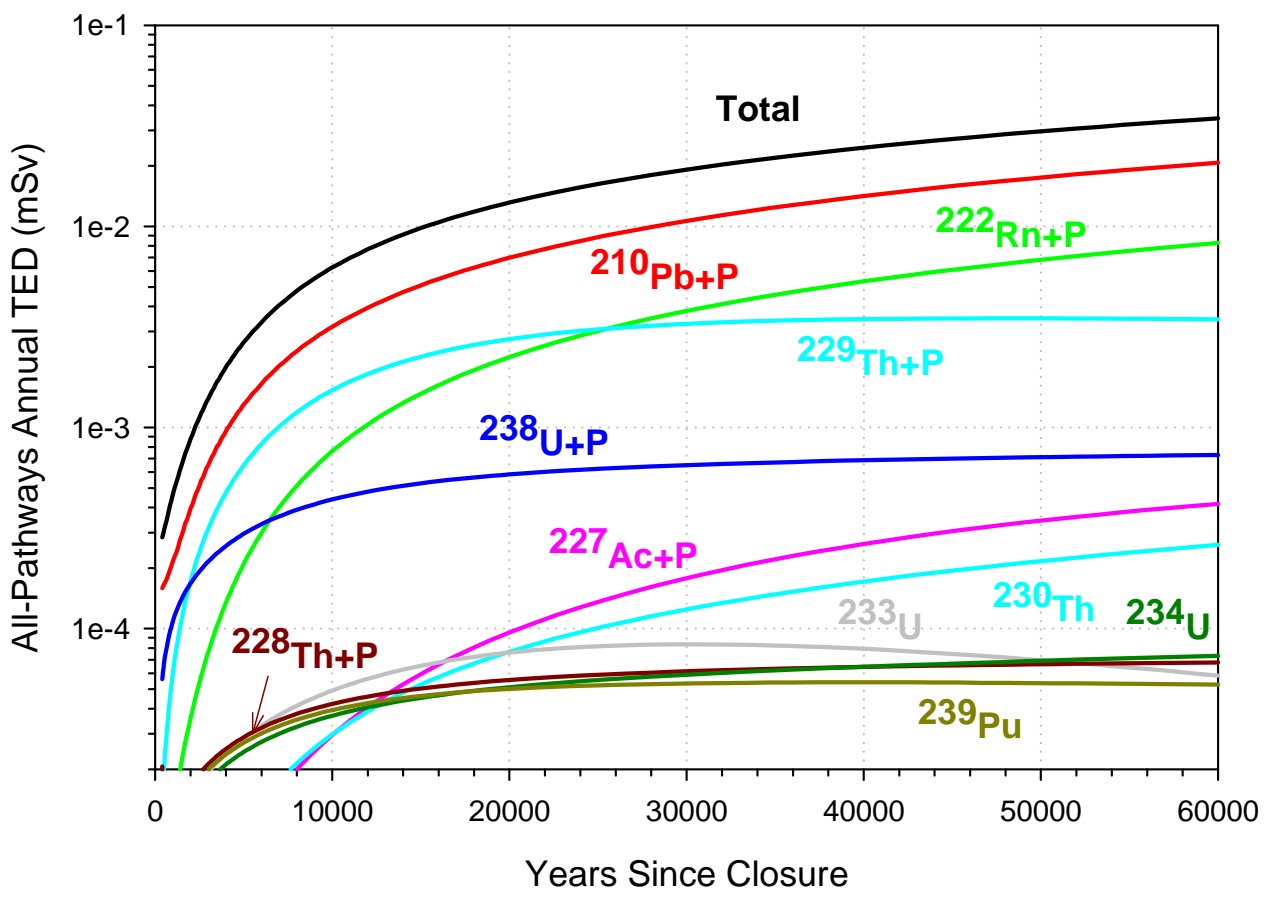

Figure 5.3 Resident all-pathways annual TED by radionuclide over 60,000 y (Case 2)

The timing and magnitude of the maximum peak dose from all waste disposed at the Area 5 RWMS continues to be controlled by ${ }^{238} \mathrm{U}$ and its progeny. The peak dose from all sources occurs beyond $1 \times 10^{6} \mathrm{y}$ and is unaffected by disposal of the CEUSP waste stream.

\subsubsection{Long-Term ${ }^{222}$ Rn Flux Density}

The ${ }^{222} \mathrm{Rn}$ flux density continues to increase beyond the 1,000-y compliance period. By 10,000 y, the mean and $95^{\text {th }}$ percentile ${ }^{222} \mathrm{Rn}$ flux densities exceed the $0.74 \mathrm{~Bq} \mathrm{~m}^{-2} \mathrm{~s}^{-1}$ performance objective (Table 5.5). The Area 5 RWMS closure cover is designed to meet the $0.74 \mathrm{~Bq} \mathrm{~m}^{-2} \mathrm{~s}^{-1}$ limit for the 1,000-y compliance period. The likelihood of compliance beyond 1,000 y can be increased by installing a thicker cover. The current requirements in DOE M 435.1-1 only require compliance for $1,000 \mathrm{y}$.

Table 5.5. Long-term ${ }^{222} \mathrm{Rn}$ flux density for the CEUSP ${ }^{233} \mathrm{U}$ waste stream averaged over the waste disposed through FY 2011

\begin{tabular}{|c|c|c|c|c|}
\hline Performance Objective & $\begin{array}{c}\text { Limit } \\
\left(\mathrm{Bq} \mathrm{m}^{-2} \mathrm{~s}^{-1}\right)\end{array}$ & $\begin{array}{c}\text { Time of } \\
\text { Maximum }\end{array}$ & $\begin{array}{c}\text { Mean } \\
\left(\mathrm{Bq} \mathrm{m}^{-2} \mathrm{~s}^{-1}\right)\end{array}$ & $\begin{array}{c}95^{\text {th }} \\
\text { Percentile } \\
\left(B q m^{-2} s^{-1}\right)\end{array}$ \\
\hline Radon Flux Density without CEUSP (Case 1) & \multirow{2}{*}{0.74} & $10,000 \mathrm{y}$ & 2.2 & 4.7 \\
\hline Radon Flux Density with CEUSP (Case 2) & & $10,000 \mathrm{y}$ & 2.3 & 4.8 \\
\hline
\end{tabular}

Comparison of the ${ }^{222} \mathrm{Rn}$ flux density with and without the CEUSP waste indicates that the CEUSP waste only slightly increases the flux (Table 5.5). The mean ${ }^{222} \mathrm{Rn}$ flux density exceeds the $0.74 \mathrm{~Bq} \mathrm{~m}^{-2} \mathrm{~s}^{-1}$ performance objective at approximately 4,200 y with the CEUSP waste 
stream and at 4,300 y without the CEUSP waste stream (Figure 5.4). The CEUSP waste stream has minimal impact on the ${ }^{222} \mathrm{Rn}$ flux density.

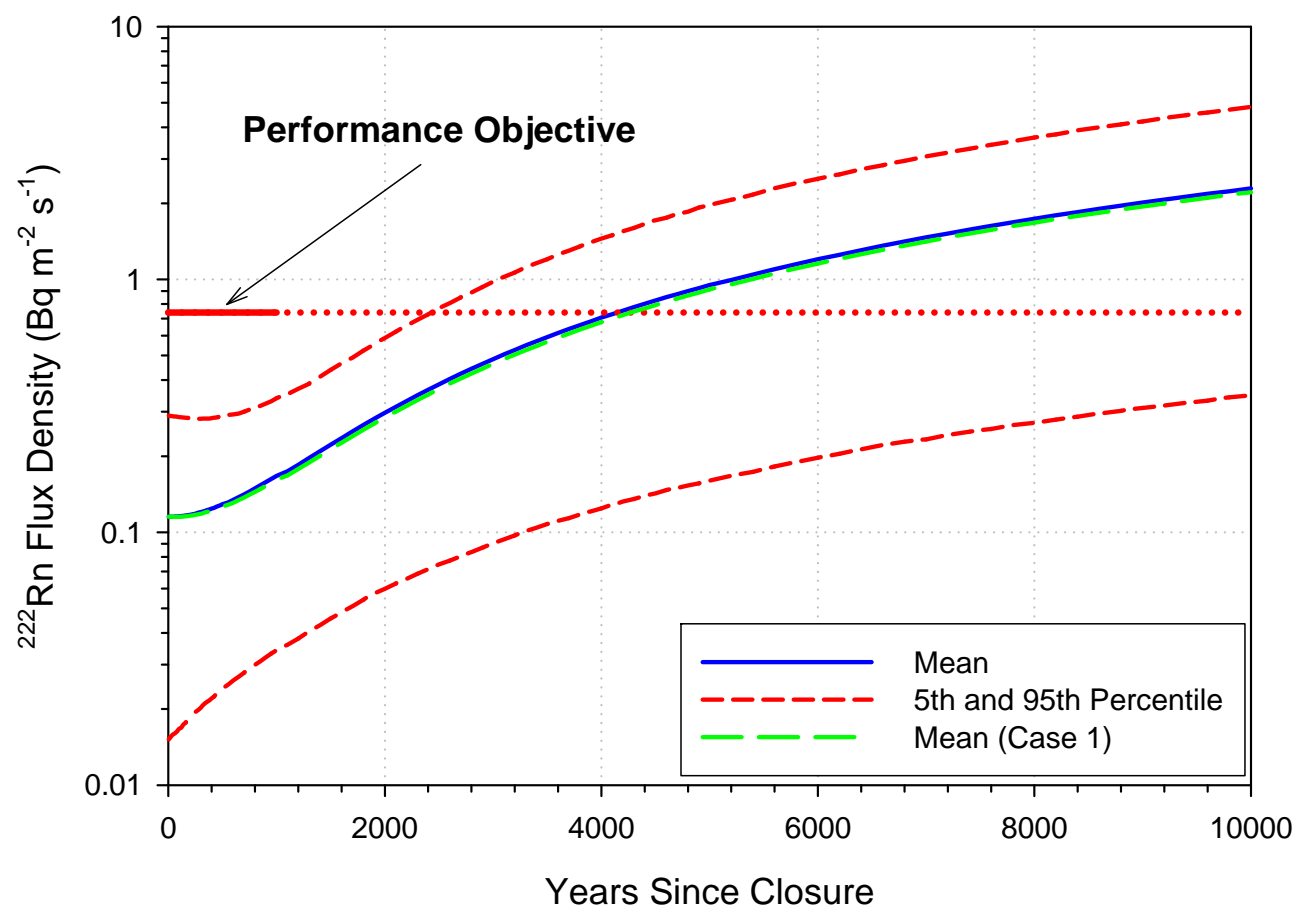

Figure $5.4{ }^{222} \mathrm{Rn}$ flux density time history over 10,000 y (Case 2 unless otherwise noted)

\subsubsection{Long-Term Intruder Results}

Intruder results are evaluated for the acute drilling scenario only. It is assumed that land-use restrictions eliminate the possibility of long-term chronic intrusion. Chronic intrusion scenarios are not evaluated. The CEUSP waste stream is assumed to be disposed below the maximum depth of common construction excavations. The acute construction scenario is not evaluated.

The acute drilling intruder TED continues to increase after 1,000 y (Table 5.6, Figure 5.5). The maximum acute drilling TED peak occurs at the end of the 10,000 y period. The mean and $95^{\text {th }}$ percentile intruder TEDs are a small fraction of the $5 \mathrm{mSv}$ performance measure. The mean is only $0.2 \%$ of the performance measure at $10,000 \mathrm{y}$.

Table 5.6. Long-term acute drilling intruder results for the OR CEUSP ${ }^{233} \mathrm{U}$ waste stream averaged over the SLB waste disposed through FY 2011

\begin{tabular}{|c|c|c|c|c|}
\hline Performance Objective & \multirow{2}{*}{$\begin{array}{c}\text { Limit } \\
\text { (mSv) }\end{array}$} & $\begin{array}{c}\text { Time of } \\
\text { Maximum }\end{array}$ & $\begin{array}{c}\text { Mean } \\
(\mathbf{m S v})\end{array}$ & $\begin{array}{c}\mathbf{9 5}^{\text {th }} \text { Percentile } \\
\text { (mSv) }\end{array}$ \\
\cline { 1 - 3 } Acute Drilling without CEUSP (Case 1) & \multirow{2}{*}{5.0} & $10,000 \mathrm{y}$ & $1.0 \mathrm{E}-2$ & $1.9 \mathrm{E}-2$ \\
\cline { 1 - 3 } Acute Drilling with CEUSP (Case 2) & & $10,000 \mathrm{y}$ & $1.2 \mathrm{E}-2$ & $2.2 \mathrm{E}-2$ \\
\hline
\end{tabular}


Disposal of the CEUSP waste increases the acute drilling intruder TED approximately 20\% at $10,000 \mathrm{y}$, but the dose in absolute terms remains a small fraction of the intruder performance measure (Figure 5.5).

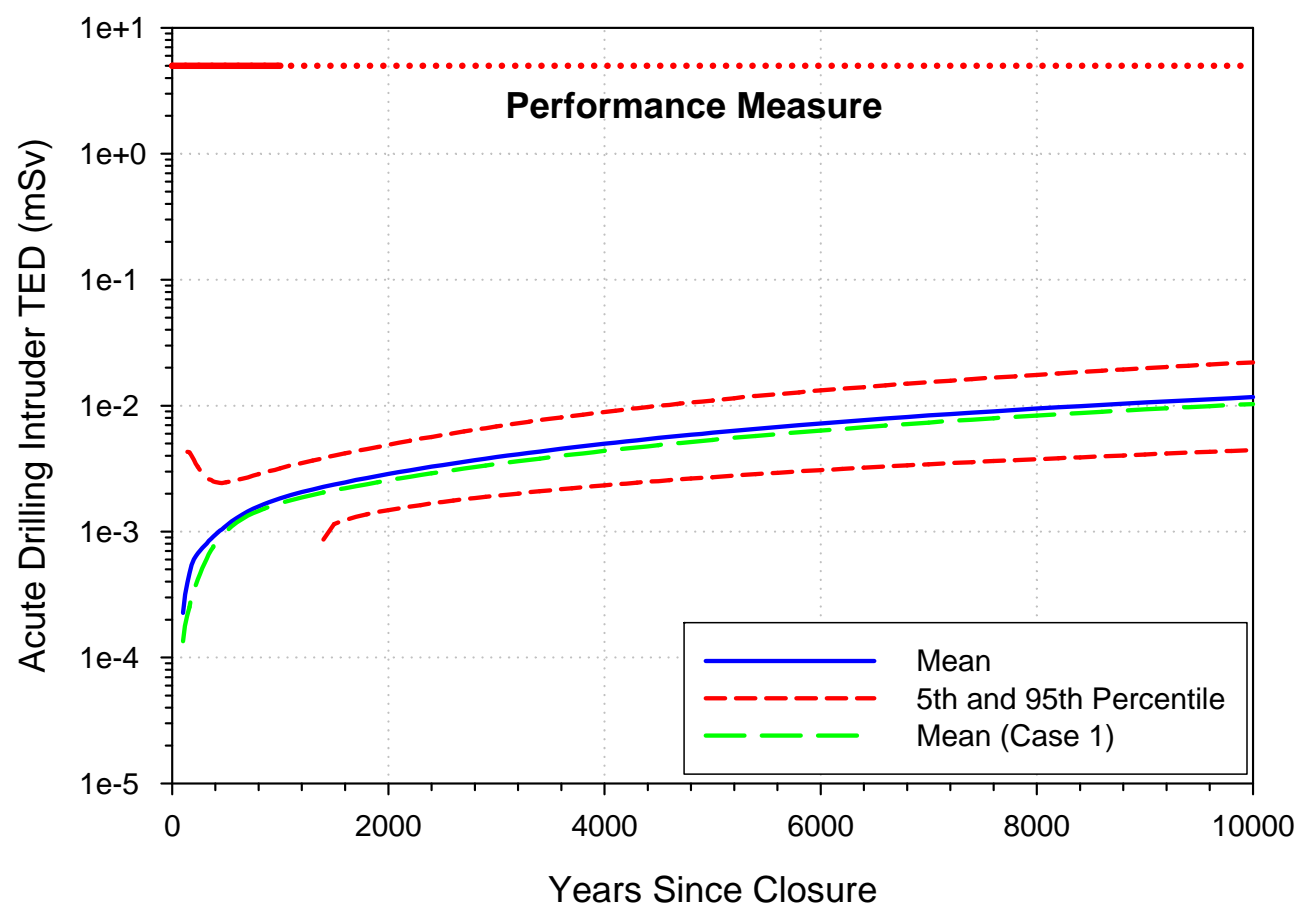

Figure 5.5 Acute drilling intruder TED time history over 10,000 y (Case 2 unless otherwise noted)

\subsection{Long-Term Effects of Containers and Depth of Burial}

The effects of containers and the depth of burial can be evaluated by comparing results for Cases 1 through 5. Case descriptions are provided in Table 3.3. The time histories of the five cases for the resident air pathway annual TED indicates that results for the first $500 \mathrm{y}$ are similar (Figure 5.6). After $500 \mathrm{y}$, the TED for Case 2 is slightly greater than the mean for the other cases. The results indicate that the addition of the CEUSP waste slightly increases the resident air pathway TED at the shallowest depth of burial considered. Cases with increased depth of burial (Cases 3, 4, and 5, see Table 3.3) are indistinguishable from Case 1 (no CEUSP ${ }^{233} \mathrm{U}$ waste), indicating that increasing the depth of burial can significantly reduce air pathway doses. 


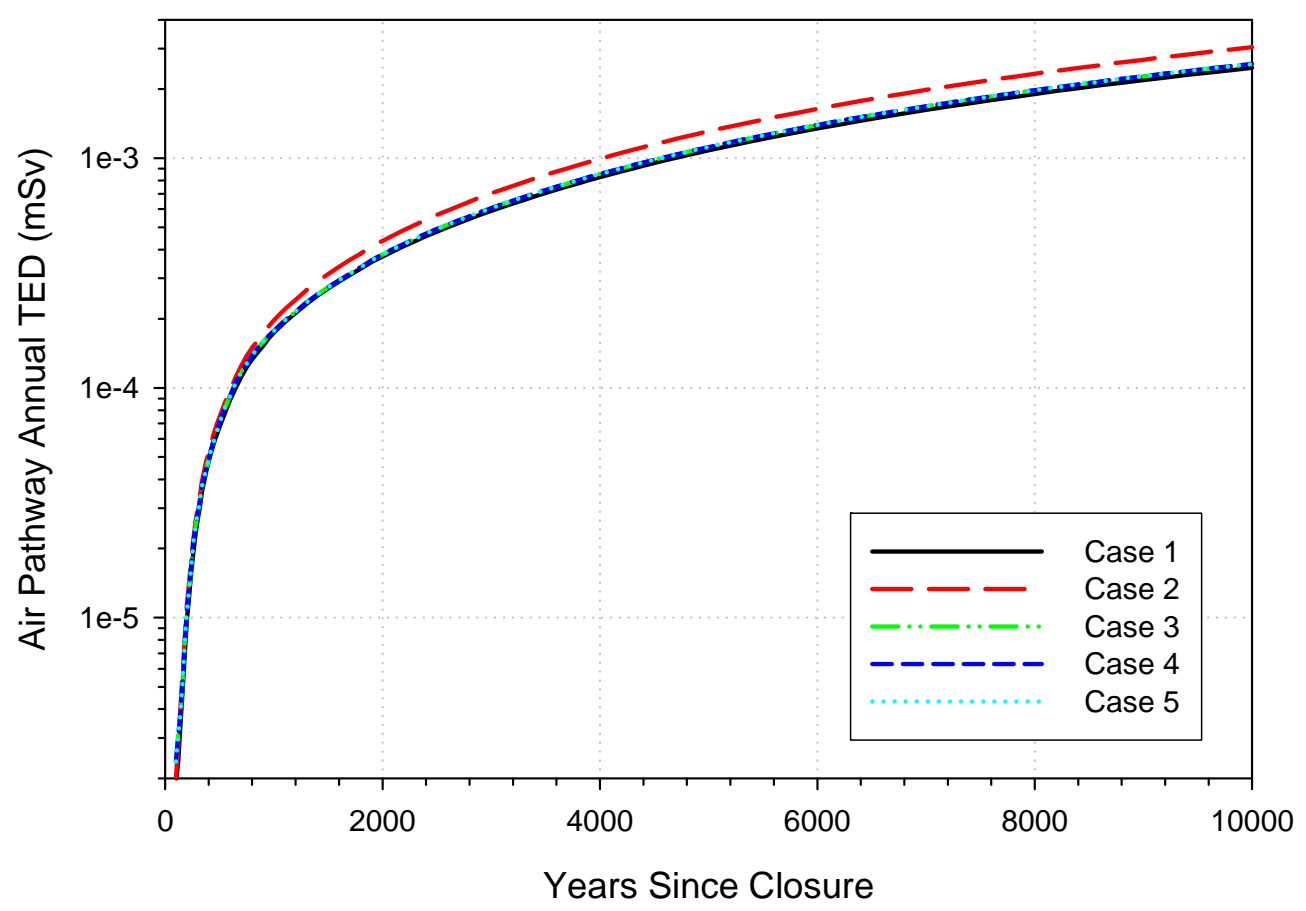

Figure 5.6 Comparison of resident air pathway annual TED time histories over 10,000 y for Cases 1 through 5 (see Table 3.3 for case definitions)

The time history for the resident all-pathways annual TED indicates that the different cases produce similar results over 10,000 y, except for Case 2, which produces slightly greater annual TED beyond 500 y (Figure 5.7). The relative increase for all-pathways exposure is less than observed for the air pathway. Again increasing the depth of burial produces results similar to Case 1 (no CEUSP ${ }^{233} U$ waste), indicating that increased depth of burial can reduce the all-pathways dose. 


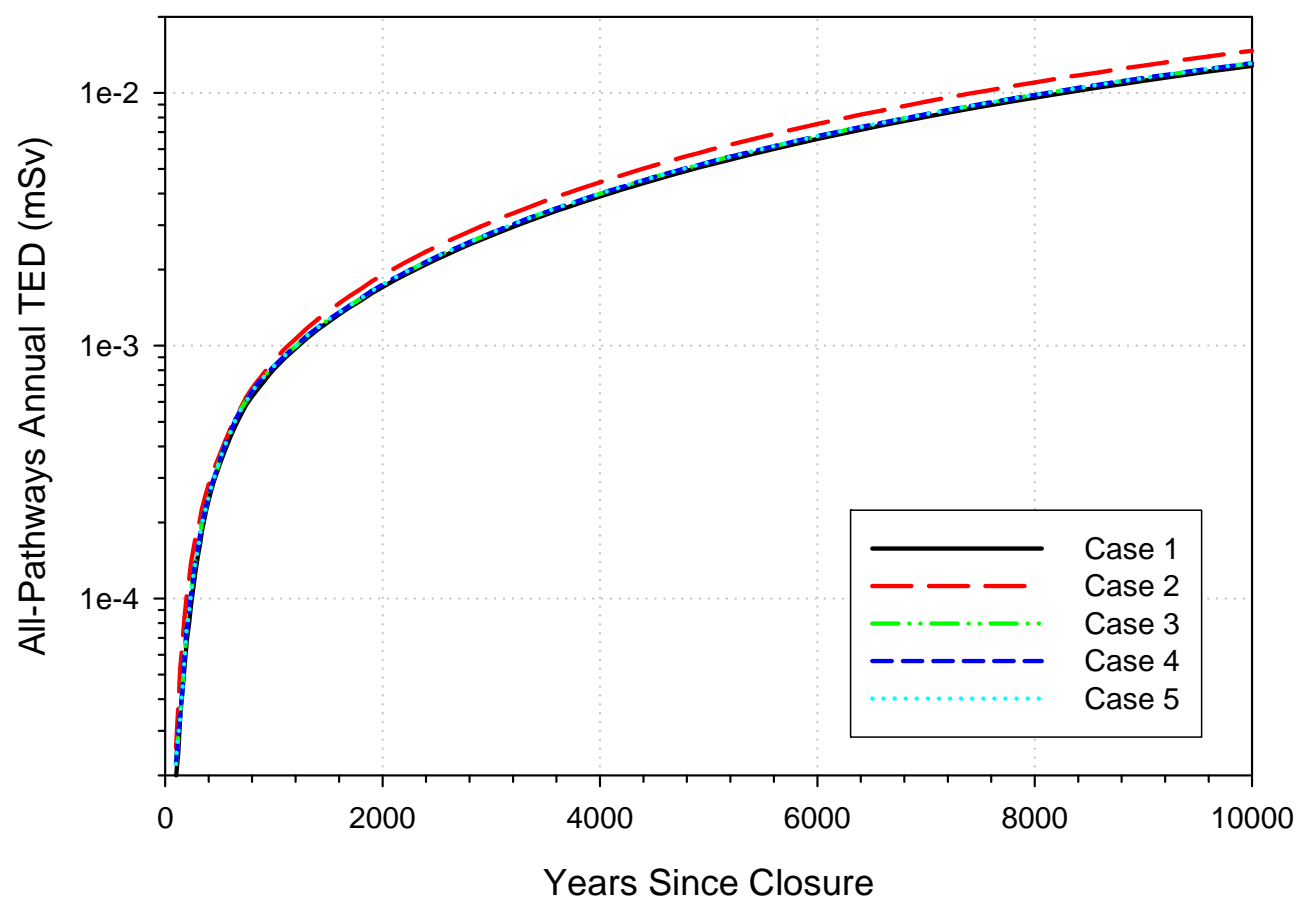

Figure 5.7 Comparison of resident all-pathways annual TED time histories over 10,000 y for Cases 1 through 5 (see Table 3.3 for case definitions)

The time history of the ${ }^{222} \mathrm{Rn}$ flux density over $10,000 \mathrm{y}$ indicates that the various cases have little effect on the flux (Figure 5.8). Addition of the CEUSP ${ }^{233} \mathrm{U}$ waste causes a very slight increase in the ${ }^{222} \mathrm{Rn}$ flux density. Increasing the depth of burial to the depth of at least Depth 1 eliminates the increase. 


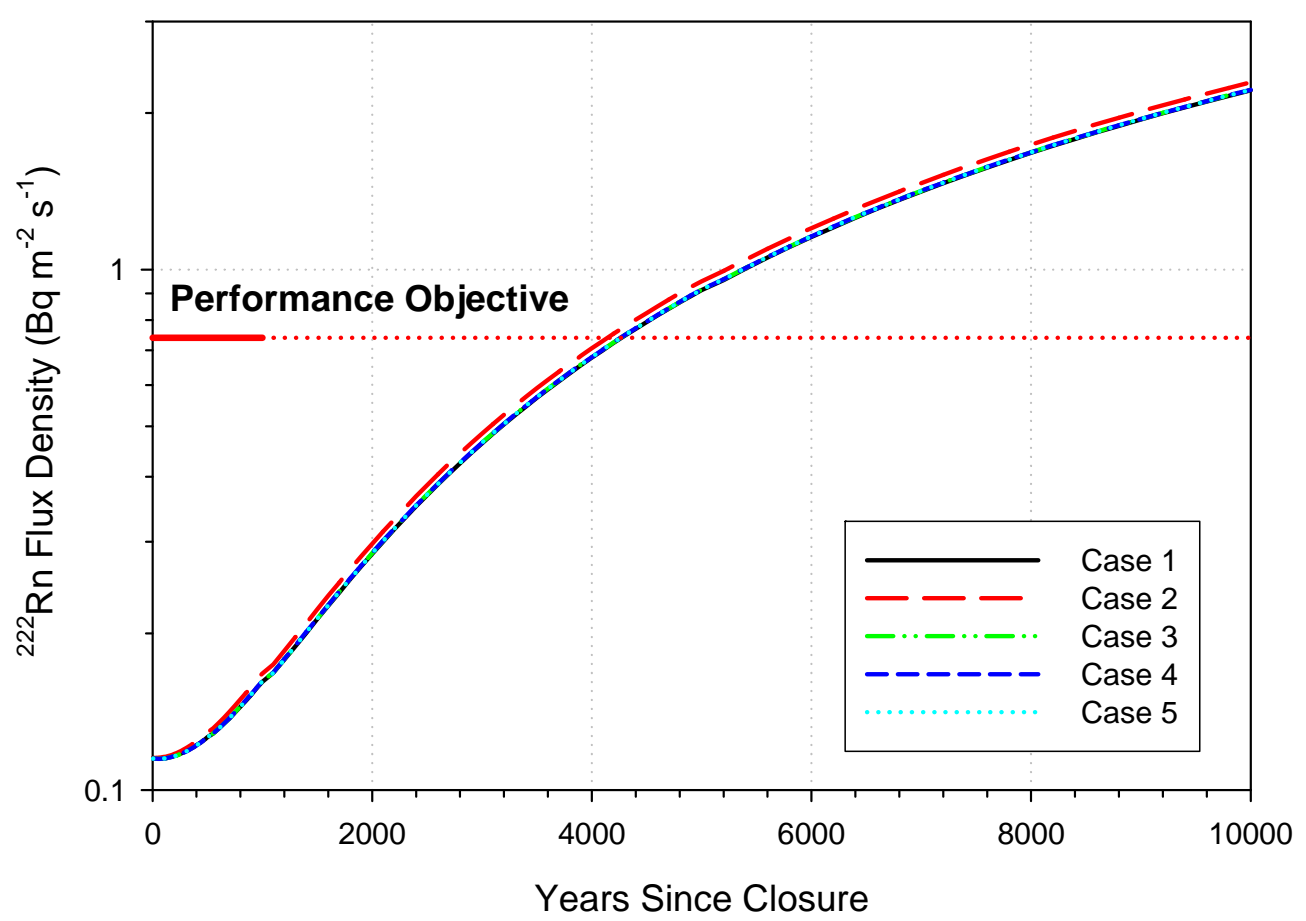

Figure 5.8 Time history of the ${ }^{222} \mathrm{Rn}$ flux density over 10,000 y for Cases 1 through 5 (see Table 3.3 for case definitions)

Comparison of the means at 1,000 y indicates that the cases produce similar results except for Case 2, which is higher (Table 5.7). This indicates that disposal of the CEUSP in a SLB trench without containers would slightly increase the resident all-pathways annual TED. Increased depth of burial reduces the CEUSP ${ }^{233} \mathrm{U}$ impacts so that it is indistinguishable from the effects without the CEUSP ${ }^{233} U$ waste. The lack of a difference between Cases 3 and 4 indicates that containers have minimal impact on performance at 1,000 y.

Table 5.7 Comparison of mean results for Cases 1 through 5 at 1,000 y (see Table 3.3 for case definitions)

\begin{tabular}{|c|c|c|c|c|c|}
\hline Pathwayl & \multicolumn{5}{|c|}{ Mean at 1,000 y } \\
\cline { 2 - 6 } $\begin{array}{c}\text { Scenario } \\
\text { Air Pathway/ } \\
\text { Resident }\end{array}$ & Case 1 & Case 2 & Case 3 & Case 4 & Case 5 \\
\hline $\begin{array}{c}\text { All-Pathways/ } \\
\text { Resident }\end{array}$ & $8.7 \mathrm{E}-4 \mathrm{mSv}-4 \mathrm{mSv}$ & $2.0 \mathrm{E}-4 \mathrm{mSv}$ & $1.8 \mathrm{E}-4 \mathrm{mSv}$ & $1.8 \mathrm{E}-4 \mathrm{mSv}$ & $1.8 \mathrm{E}-4 \mathrm{mSv}$ \\
\hline $\begin{array}{c}\text { 222 Rn Flux } \\
\text { Density/All Units }\end{array}$ & $0.16 \mathrm{~Bq} \mathrm{~m}^{-2} \mathrm{~s}^{-1}$ & $0.17 \mathrm{~Bq} \mathrm{~m}-4 \mathrm{mSv}$ & $8.3 \mathrm{E}-4 \mathrm{mSv}$ & $8.3 \mathrm{E}-4 \mathrm{mSv}$ & $8.3 \mathrm{E}-4 \mathrm{mSv}$ \\
\hline
\end{tabular}

The results at $10,000 \mathrm{y}$ increase relative to the $1,000 \mathrm{y}$ results (Table 5.8). The relative differences among model cases are similar to that observed at 1,000 y. The addition of the CEUSP ${ }^{233} U$ waste causes small increases in the air pathway and all-pathways annual TED, and a much smaller increase in the ${ }^{222} \mathrm{Rn}$ flux density. Increasing the depth of burial effectively eliminates any increase caused by disposal of the CEUSP ${ }^{233} \mathrm{U}$ waste. 
Table 5.8 Comparison of mean results for Cases 1 through 5 at 10,000 y

\begin{tabular}{|c|c|c|c|c|c|}
\hline Pathwayl & \multicolumn{5}{|c|}{ Mean at 10,000 y } \\
\cline { 2 - 6 } Scenario & Case 1 & Case 2 & Case 3 & Case 4 & Case 5 \\
\hline $\begin{array}{c}\text { Air Pathway/ } \\
\text { Resident }\end{array}$ & $2.5 \mathrm{E}-3 \mathrm{mSv}$ & $3.0 \mathrm{E}-3 \mathrm{mSv}$ & $2.6 \mathrm{E}-3 \mathrm{mSv}$ & $2.6 \mathrm{E}-3 \mathrm{mSv}$ & $2.6 \mathrm{E}-3 \mathrm{mSv}$ \\
\hline $\begin{array}{c}\text { All-Pathways/ } \\
\text { Resident }\end{array}$ & $1.3 \mathrm{E}-2 \mathrm{mSv}$ & $1.5 \mathrm{E}-2 \mathrm{mSv}$ & $1.3 \mathrm{E}-2 \mathrm{mSv}$ & $1.3 \mathrm{E}-2 \mathrm{mSv}$ & $1.3 \mathrm{E}-2 \mathrm{mSv}$ \\
\hline $\begin{array}{c}{ }^{222} \mathrm{Rn} \text { Flux } \\
\text { Density/All Units }\end{array}$ & $2.2 \mathrm{~Bq} \mathrm{~m}^{-2} \mathrm{~s}^{-1}$ & $2.3 \mathrm{~Bq} \mathrm{~m} \mathrm{~s}^{-1}$ & $2.2 \mathrm{~Bq} \mathrm{~m}^{-2} \mathrm{~s}^{-1}$ & $2.2 \mathrm{~Bq} \mathrm{~m}^{-2} \mathrm{~s}^{-1}$ & $2.2 \mathrm{~Bq} \mathrm{~m}^{-2} \mathrm{~s}^{-1}$ \\
\hline
\end{tabular}

Boxplots of the resident all-pathway annual TED at 10,000 y for all the cases indicates again that there is little difference between the five cases (Figure 5.9). Overlap in the notches in the boxplots indicates that there is no significant difference in the medians. Case 2 is the only case with a significantly different median. The quartiles and ranges of the data are all similar. Overall, these results indicate that addition of the CEUSP ${ }^{233} \mathrm{U}$ waste has minimal impact on the performance of the Area 5 RWMS over 10,000 y. Increasing the depth of burial to at least Depth 1 eliminates whatever small increase the CEUSP ${ }^{233} \mathrm{U}$ causes. The container degradation model has minimal impact on the long-term performance of the CEUSP ${ }^{233} U$ waste. The container degradation process, specifically pitting corrosion of stainless steel, is insufficiently characterized to support a conclusion that containers can persist long enough to impact the release of the CEUSP ${ }^{233} \mathrm{U}$ waste.

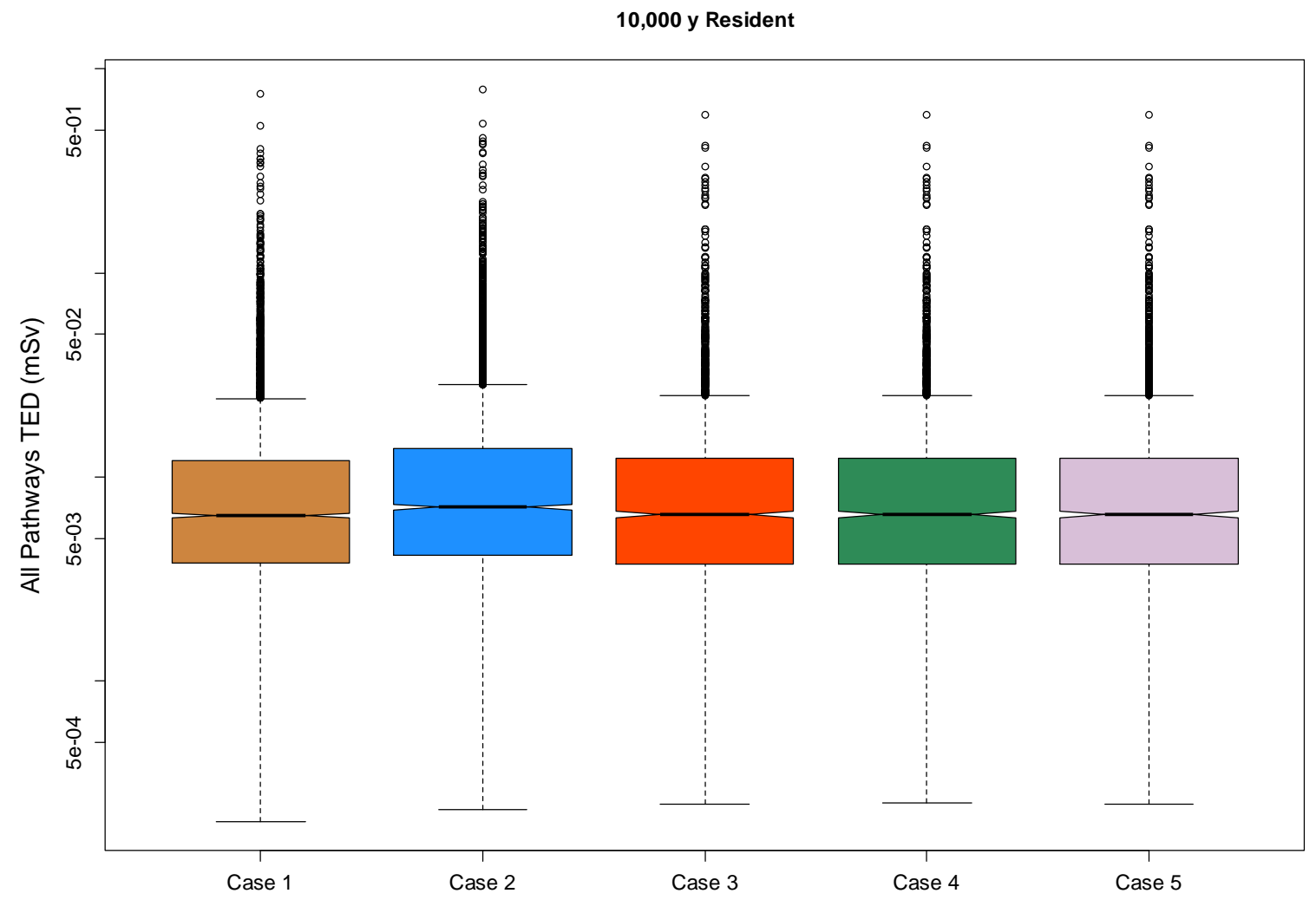

Figure 5.9 Boxplots of the resident all-pathways annual TED at 10,000 y for Cases 1 through 5 (see Table 3.3 for case definitions) 
This Page Intentionally Left Blank 


\subsection{Conclusions}

The results of the SA indicate that there is a reasonable expectation of compliance with all performance objectives with the OR CEUSP ${ }^{233} \mathrm{U}$ waste stream disposed in the Area 5 RWMS SLB disposal units. The maximum mean and $95^{\text {th }}$ percentile results are all less than their respective performance objectives for $1,000 \mathrm{y}$. Monte Carlo uncertainty analysis indicates that there is a high likelihood of compliance with all performance objectives for a period of 1,000 $\mathrm{y}$ after closure with the addition of the CEUSP ${ }^{233} \mathrm{U}$ waste.

The relative impact of the OR CEUSP ${ }^{233} \mathrm{U}$ waste stream can be evaluated by comparing the SA results with the results of the FY 2011 inventory without the CEUSP ${ }^{233} U$. The addition of the CEUSP waste stream increases the results for almost all SA results, but the increases are modest in absolute terms (Table 6.1). The largest relative increase, 18\%, occurs for the air pathway resident scenario, but the absolute result remains a small fraction $(0.2 \%)$ of the performance objective.

Table 6.1 Comparison of mean SA results with and without the OR CEUSP ${ }^{233} \mathrm{U}$ waste stream at 1,000 y

\begin{tabular}{|c|c|c|c|c|}
\hline Performance Objective & Limit & $\begin{array}{l}\text { Time of } \\
\text { Maximum }\end{array}$ & $\begin{array}{c}\text { Mean }^{\dagger} \text { without } \\
\text { CEUSP } \\
\text { (Case 1) }\end{array}$ & $\begin{array}{l}\text { Mean }^{\dagger} \text { with } \\
\text { CEUSP } \\
\text { (Case 2) }\end{array}$ \\
\hline Air Pathway/Transient Occupancy & $0.1 \mathrm{mSv}$ & 1,000 y & $8.9 E-5$ & $1.0 \mathrm{E}-4$ \\
\hline Air Pathway/Resident & $0.1 \mathrm{mSv}$ & $1,000 \mathrm{y}$ & $1.7 \mathrm{E}-4$ & $2.0 \mathrm{E}-4$ \\
\hline Air Pathway/Resident Farmer & $0.1 \mathrm{mSv}$ & $1,000 \mathrm{y}$ & $4.8 \mathrm{E}-4$ & $5.5 \mathrm{E}-4$ \\
\hline Air Pathway/Cane Spring & $0.1 \mathrm{mSv}$ & $1,000 \mathrm{y}$ & 4.7E-9 & $5.4 \mathrm{E}-9$ \\
\hline Air Pathway/NNSS Boundary & $0.1 \mathrm{mSv}$ & $1,000 y$ & 8.0E-8 & $9.1 \mathrm{E}-8$ \\
\hline All-Pathways/Transient Occupancy & $0.25 \mathrm{mSv}$ & $1,000 y$ & $4.8 \mathrm{E}-3$ & $5.0 \mathrm{E}-3$ \\
\hline All-Pathways/Resident & $0.25 \mathrm{mSv}$ & $1,000 \mathrm{y}$ & $8.1 \mathrm{E}-4$ & 8.7E-4 \\
\hline All-Pathways/Resident Farmer & $0.25 \mathrm{mSv}$ & $1,000 \mathrm{y}$ & $1.9 \mathrm{E}-2$ & 2.0E-2 \\
\hline All-Pathways/Cane Spring & $0.25 \mathrm{mSv}$ & $1,000 \mathrm{y}$ & $1.7 \mathrm{E}-3$ & $1.7 \mathrm{E}-3$ \\
\hline All-Pathways/NNSS Boundary & $0.25 \mathrm{mSv}$ & $1,000 \mathrm{y}$ & $1.9 \mathrm{E}-3$ & $1.9 \mathrm{E}-3$ \\
\hline Radon Flux Density & $0.74 \mathrm{~Bq} \mathrm{~m}^{-2} \mathrm{~s}^{-1}$ & 1,000 y & 0.16 & 0.17 \\
\hline Acute Drilling (All SLB) & $5.0 \mathrm{mSv}$ & $1,000 \mathrm{y}$ & $1.7 \mathrm{E}-3$ & $1.8 \mathrm{E}-3$ \\
\hline
\end{tabular}

${ }^{\dagger}$ - The mean is reported in the same units as the corresponding limit

The Area 5 RWMS has natural characteristics, engineered barriers, and administrative controls that enhance long-term stability and security. The Area 5 RWMS has limited potential for future residential or agricultural development due to its location in an extremely arid region with infertile soils and few attractive resources. Transport of contaminants to the uppermost aquifer is extremely unlikely under current climatic conditions. The national security mission of the NNSS and the presence of residual radioactive contamination require indefinite government ownership and control of land.

The long-term performance of the OR CEUSP ${ }^{233} \mathrm{U}$ waste stream for near-surface disposal was evaluated by performing long-term (i.e., 10,000 and 60,000 y) analyses. The mean and $95^{\text {th }}$ 
percentile for the resident air pathway annual TED, the resident all-pathways annual TED, and the acute drilling TED are less than their performance objectives for 10,000 y after closure. The peak dose from CEUSP key radionuclides is expected by 48,000 y. The resident all-pathways annual TED at 48,000 y, $0.03 \mathrm{mSv}$, is less than the $0.25 \mathrm{mSv}$ performance objective.

The ${ }^{222} \mathrm{Rn}$ flux density exceeds the performance objective at $4,200 \mathrm{y}$, but this is due to waste already disposed in the Area 5 RWMS. Disposal of the CEUSP ${ }^{233}$ U waste stream has minimal impacts on the ${ }^{222} \mathrm{Rn}$ flux density.

Increasing the depth of disposal of the OR CEUSP ${ }^{233} \mathrm{U}$ waste stream was found to reduce the small impacts of the waste stream. The two deepest disposal depths (Depths 1 and 2) were sufficient to make disposal of the OR CEUSP ${ }^{233} \mathrm{U}$ waste stream indistinguishable from baseline performance without the OR CEUSP ${ }^{233} \mathrm{U}$ waste stream. Containers could not be shown to have any significant impact on performance due to the long half-life of the waste stream and to a lack of data about pitting corrosion of stainless steel in soil.

The results of the SA indicate that all performance objectives can be met with disposal of the OR CEUSP ${ }^{233} \mathrm{U}$ waste stream in the SLB disposal units at the Area 5 RWMS. The long-term performance of the OR CEUSP ${ }^{233} \mathrm{U}$ waste stream from 1,000 y until the time of peak dose at $48,000 \mathrm{y}$ is protective of public health and the environment. The waste stream is recommended for disposal without conditions. 


\subsection{References}

Adler Flitton, K. M., C. W. Bishop, R. E. Mizia, L. L. Torres, and R. D. Rogers, 2001. Long-Term Corrosion/Degradation Test Third Year Results. Idaho Falls, ID: Idaho National Engineering and Environmental Laboratory, INEEL/EXT-01-00036-Rev 0.

Adler Flitton, K. M., C. W. Bishop, and R. E. Mizia, 2002.Underground Corrosion of Activated Metals in an Arid Vadose Zone Environment. Idaho Falls, ID: Idaho National Engineering and Environmental Laboratory, INEEL/CON-01-01450.

Adler Flitton, K. M.,and T. S. Yoder, 2006.Underground Corrosion of Activated Metals: 6-Year Exposure Analysis. Idaho Falls, ID: Idaho National Engineering and Environmental Laboratory, INEEL/CON-05-00761.

Adler Flitton, K. M., and T. S. Yoder, 2012.Twelve Year Study of Underground Corrosion of Activated Metals. Idaho Falls, ID: Idaho National Engineering and Environmental Laboratory, INL/CON-12-27603.

Andraski, B. J., 1997. Soil-Water Movement under Natural Site and Waste-Site Conditions: A Multiple-Year Field Study in the Mojave Desert, Nevada. Water Resources Res. 33(8): 1901-1916.

Bechtel Nevada, 2005. Data Report: Groundwater Monitoring Program Area 5 Radioactive Waste Management Site. Las Vegas, NV: Bechtel Nevada, DOE/NV/11718--1015.

Bechtel Nevada, 2006a. Addendum 2 to the Performance Assessment for the Area 5 Radioactive Waste Management Site at the Nevada Test Site, Nye County, Nevada: Update of Performance Assessment Methods and Results. Las Vegas, NV: Bechtel Nevada. DOE/NV/11718--176ADD2.

Bechtel Nevada, 2006b. A Hydrostratigraphic Model and Alternatives for the Groundwater Flow and Contaminant Transport Model of Corrective Action Unit 97: Yucca Flat-Climax Mine, Lincoln and Nye Counties, Nevada. Las Vegas, NV: Bechtel Nevada, DOE/NV/11718--1119.

Bechtel SAIC, see Bechtel Science Applications International Corporation.

Bechtel Science Applications International Corporation, 2004a. Future Climate Analysis. Las Vegas, NV: Bechtel SAIC, ANL-NBS-GS-000008 Rev. 1, September 2004.

Bechtel Science Applications International Corporation, 2004b. Technical Basis Document No. 1: Climate and Infiltration. Las Vegas, NV: Bechtel SAIC, Rev. 1, May 2004.

Black, P., K. Black, L. Stahl, M. Hooten, T. Stockton, and D. Neptune. 2001. Assessing the Probability of Inadvertent Human Intrusion at the Nevada Test Site Radioactive Waste Management Sites, Vols I and II. Las Vegas, NV: U.S. Department of Energy, Nevada Operations Office, DOE/NV--593-Vol. I, II. 
Blout, D. O., W. S. Birchfiel, D. P. Hammermeister, K. A. Zukosky, and K. D. Donnelson, 1995. Site Characterization Data from the Area 5 Science Boreholes, Nevada Test Site, Nye County, Nevada. Las Vegas, NV: Reynolds Electrical and Engineering Co. Inc. DOE/NV/11432--170.

BN, see Bechtel Nevada.

Carr, W. J., G. D. Bath, D. L. Healey, and R. M. Hazlewood. 1975. Geology of Northern Frenchman Flat, Nevada Test Site. Washington, D.C.: U.S. Geological Survey , USGS474-216.

Carr, W. J., 1984. Regional Structural Setting of Yucca Mountain, Southwestern Nevada, and Late Cenozoic Rates of Tectonic Activity in Parts of the Southwestern Great Basin, Nevada and California. U.S. Geological Survey Open-File Report 84-854.

Case, C., J. Davis, R. French, and S. Raker, 1984. Site Characterization in Connection with the Low Level Defense Waste Management Site in Area 5 of the Nevada Test Site, Nye County, Nevada, Final Report. Las Vegas, NV: Desert Research Institute, Publication No. 45034.

Castor, S. B., S. C. Feldman, and J. V. Tingley, 1990. Mineral Evaluation of the Yucca Mountain Addition, Nye County, Nevada. Reno, NV: Nevada Bureau of Mines and Geology, Open File Report 90-4.

CFR, see Code of Federal Regulations.

Cochran, J. R., W. E. Beyeler, D. A. Brosseau, L. H. Brush, T. J. Brown, B. Crowe, S. H. Conrad, P. A. Davis, T. Ehrhorn, T. Feeney, B. Fogleman, D. P. Gallegos, R. Haaker, E. Kalinina, L. L. Price, D. P. Thomas, and S. Wirth, 2001. Compliance Assessment Document for the Transuranic Wastes in the Greater Confinement Disposal Boreholes at the Nevada Test Site. Albuquerque, NM: Sandia National Laboratories, SAND2001-2977, September 2001.

Code of Federal Regulations, 1980. Title 40 CFR Part 265, Interim Status Standards for Owners and Operators of Hazardous Waste Treatment, Storage, and Disposal Facilities. Washington, D.C.: U.S. Government Printing Office.

Code of Federal Regulations, 1994. Title 40 CFR Part 191, Environmental Radiation Protection Standards for Management and Disposal of Spent Nuclear Fuel, High-Level and Transuranic Radioactive Wastes. Washington, D.C.: U.S. Government Printing Office.

Code of Federal Regulations, 2001. Title 40 CFR Part 197, Public Health and Environmental Radiation Protection Standards for Yucca Mountain, Nevada. Washington, D.C.: U.S. Government Printing Office.

Code of Federal Regulations, 2008. Title 10 CFR Part 61, Licensing Requirements for Land Disposal of Radioactive Waste. Washington, D.C.: U.S. Government Printing Office. 
Code of Federal Regulations, 2012. Title 40 CFR Part 141, National Primary Drinking Water Regulations. Washington, D.C.: U.S. Government Printing Office.

Connor, C. B., J. A. Stamatakos, D. A. Ferrill, B. E. Hill, G. I. Ofoegbu, F. M. Conway, B. Sagar, and J. Trapp, 2000. Geologic Factors Controlling Patterns of Small-Volume Basaltic Volcanism: Application to a Volcanic Hazards Assessment at Yucca Mountain, Nevada. J. of Geophysical Research 105: 417-432.

Crowe, B. M., 1990. Basaltic Volcanic Episodes of the Yucca Mountain Region. In Proceedings of the International Meeting on High-Level Radioactive Waste Management. 65-73. Las Vegas, Nevada: American Nuclear Society.

Crowe, B. M., P. Wallmann, and L. M. Bowker, 1998. Probabilistic Modeling of Volcanism Data: Final Volcanic Hazard Studies for the Yucca Mountain site. In Volcanism Studies: Final Report for the Yucca Mountain Project, ed. F. V. Perry, B. M. Crowe, G. A. Valentine, and L. M. Bowker. Los Alamos, NM: Los Alamos National Laboratory Report LA-13478.

DOE, see U.S. Department of Energy.

DOE/NV, see U.S. Department of Energy, Nevada Operations Office.

Duratek, 2012. CEUSP Waste Profile Sheet. Oak Ridge, TN: Energy Solutions/Duratek. August 9, 2012.

Federal Facility Agreement and Consent Order, 1996 (as amended March 2010). Agreed to by the State of Nevada; U.S. Department of Energy, Environmental Management; U.S. Department of Defense; and U.S. Department of Energy, Legacy Management. Appendix VI, Revision No. 4.

FFACO, see Federal Facility Agreement and Consent Order.

Fleck, R. J., B. D. Turrin, D. A. Sawyer, R. G. Warren, D. E. Champion, M. R. Hudson, and S. A. Minor, 1996. Age and Character of Basaltic Rocks of the Yucca Mountain Region. J. of Geophysical Research 101: 8205-8227.

Forester, R. M., J. P. Bradbury, C. Carter, A. B. Elvidge-Tuma, M. L. Hemphill, S. C. Lundstrom, B. D. Mahan, L. A. Neymark, J. B. Paces, S. E. Sharpe, J. F. Whelan, and P. E. Wigland, 1999. The Climatic and Hydrologic History of Southern Nevada During the Late Quaternary. Denver, CO: U.S. Geological Survey Open-File Report 98--635.

Garside, L. J., R. H. Hess, K. L. Fleming, and B. S. Weimer, 1988. Oil and Gas Developments in Nevada. Reno, NV: Nevada Bureau of Mines and Geology, Bulletin 104.

Gustafson, D. L., S. E. Rawlinson, and J. J. Miller, 2007. Summary of Natural Resources that Potentially Influence Human Intrusion at the Area 5 Radioactive Waste Management Site DOE/Nevada Test Site, Nye County, Nevada. Las Vegas, NV: National Security Technologies, LLC, DOE/NV/25946--198. 
Heizler, M. T., F. V. Perry, B. M. Crowe, L. Peters, and R. Appelt, 1999. The Age of the Lathrop Wells Volcanic Center: $\mathrm{An}{ }^{40} \mathrm{Ar} /{ }^{39} \mathrm{Ar}$ Dating Investigation. J. of Geophysical Research 104: 767-804.

International Atomic Energy Agency, 1999. Near Surface Disposal of Radioactive Waste Safety Requirements. Vienna, Austria: IAEA Safety Standards Series WS-R-1.

Isotek, 2012a. CEUSP Material Characteristics. Oak Ridge, TN: Isotek Systems LLC. ISO-SAF-WP-101, Rev. 0.

Isotek, 2012b. Nuclear Criticality Safety Evaluation: CEUSP Disposal at Nevada National Security Site. Oak Ridge, TN: Isotek Systems LLC, ISO-NCS-CSE-013, Rev. 1.

Istok, J. D., D. O. Blout, L. Barker, K. R. Johnejack, and D. P. Hammermeister, 1994. Spatial Variability in Alluvium Properties at a Low-Level Nuclear Waste Site. Soil Sci. Soc. Am. J. 58: 1040-1051.

Kemnitz, M., 1999. Seismic Evaluation of the U3ax/bl landfill in the Area 3 RWMS, Nevada Test Site, Nevada. Las Vegas, NV: University of Nevada, Las Vegas, Unpublished master's thesis.

Laczniak, R. J., J. C. Cole, D. A. Sawyer, and D. A. Trudeau, 1996. Summary of Hydrogeologic Controls on Groundwater Flow at the Nevada Test Site, Nye County, Nevada. Denver, CO: U.S. Geological Survey, Water-Resources Investigation Report 96-4109.

Mann, F. M., R. J. Puigh, S. H. Finfrock, R. Khaleel, and M. I. Wood, 2003. Integrated Disposal Facility Risk Assessment. Richland, WA: CH2M Hill Hanford Group, Inc, RPP-15834.

Mughabghab, S. F., and T. M. Sullivan, 1989. Evaluation of the Pitting Corrosion of Carbon Steels and other Ferrous Metals in Soil Systems. Waste Management 9: 239-251.

National Academy of Sciences, 1995. Ward Valley: An Examination of Seven Issues in Ecology and Earth Sciences. Washington, D.C.: National Academies Press.

National Security Technologies, LLC, 2007. Passive Barriers to Inadvertent Human Intrusion for Use at the Nevada Test Site. Las Vegas, NV: National Security Technologies, LLC, DOE/NV/25946--206.

National Security Technologies, LLC, 2008. Closure Plan for the Area 5 Radioactive Waste Management Sites at the Nevada Test Site. Las Vegas, NV: National Security Technologies, LLC, DOE/NV/25946--553.

National Security Technologies, LLC, 2012a. 2011 Annual Summary Report for the Area 3 and Area 5 Radioactive Waste Management Sites at the Nevada National Security Site, Nye County, Nevada. Las Vegas, NV: National Security Technologies, LLC.

DOE/NV/25946--1451. 
National Security Technologies, LLC, 2012b. Nevada National Security Site Environmental Report 2011. Las Vegas, NV: National Security Technologies, LLC.

DOE/NV/25946--1604.

Navarro-Intera, LLC, 2010. External Peer Review Team Report Underground Testing Area Subproject for Frenchman Flat. Las Vegas, NV: Navarro-Intera, Report N-I/28091-021.

NNSA/NSO, see U.S. Department of Energy, National Nuclear Security Administration Nevada Site Office.

NRC, see U.S. Nuclear Regulatory Commission.

NSTec, see National Security Technologies, LLC.

Ostler, K. W., D. J. Hansen, D. C. Anderson, and D. B. Hall, 2000. Classification of Vegetation of the Nevada Test Site. Las Vegas, NV: Bechtel Nevada, DOE/NV/11718--477.

Raytheon Services Nevada, 1994. Summary of Volcanic Activity at the Area 5 Radioactive Waste Management Site, Department of Energy, Nevada Test Site, Nye County, Nevada. Las Vegas, NV: Raytheon Services Nevada, Letter Report.

Reynolds Electrical and Engineering Company, 1993. Hydrogeologic Data for Science Trench Boreholes at the Area 5 Radioactive Waste Management Site, Nevada Test Site, Nye County, Nevada. Las Vegas, NV: Reynolds Electrical and Engineering Co. Inc., DE-AC08-NV11432--170.

Reynolds Electrical and Engineering Company, 1994. Site Characterization and Monitoring Data from Area 5 Pilot Wells, Nevada Test Site, Nye County, Nevada. Las Vegas, NV: Reynolds Electrical and Engineering Co. Inc., DOE/NV/11432--74.

Richard-Haggard, K., 1983. Economic Potential of Alternative Land and Natural Resources Uses at the Nevada Test Site, Nye County, Nevada. Las Vegas, NV: Desert Research Institute, Publication No. 45030.

Riley, R. G., and C. A. Lo Presti, 2004. Recommended Parameter Values for INEEL Subsurface Disposal Area Source Release Problem. Richland, WA: Pacific Northwest National Laboratories, PNNL-14742.

Romanoff, M., 1957. Underground Corrosion. Washington, D.C.: National Bureau of Standards, NBS Circular 579, PB-168350.

Sawyer, D. A., R. J. Fleck, M. A. Lanphere, R. G. Warren, D. E. Broxton, and M. R. Hudson, 1994. Episodic Caldera Volcanism in the Miocene Southwestern Nevada Volcanic Field: Revised Stratigraphic Framework, ${ }^{40} \mathrm{Ar} /{ }^{39} \mathrm{Ar}$ Geochronology, and Implications for Magmatism and Extension. Geological Society of America Bull.: 1304-1318.

Scanlon, B. R., R. P. Langford, and R. S. Goldsmith, 1999. Relationship Between Geomorphic Settings and Unsaturated Flow in an Arid Setting. Water Resources Research 35: 983-999. 
Scanlon, B. R., K. Keese, R. C. Reedy, J. Simunek, and B. J. Andraski, 2003. Variations in Flow and Transport in Thick Desert Vadose Zones in Response to Paleoclimatic Forcing (0-90 kyr): Field Measurements, Modeling, and Uncertainties. Water Resources Research 39: 1179-1197.

Shott, G. J., L. E. Barker, S. E. Rawlinson, M. J. Sully, and B. A. Moore, 1998. Performance Assessment for the Area 5 Radioactive Waste Management Site, Nye County, Nevada. Las Vegas, NV: Bechtel Nevada. DOE/NV/11718--176.

Shott, G. J., V. Yucel, and L. Desotell, 2008. Special Analysis of Transuranic Waste in Trench T04C at the Area 5 Radioactive Waste Management Site, Nevada Test Site, Nye County, Nevada, Revision 1. Las Vegas, NV: National Security Technologies, LLC. DOE/NV/25946--470.

State of Nevada Demographer, 2013. 2011 Estimates: Estimates by County, City, and Unincorporated Town. Available online at: http://nvdemography.org/data-andpublications/estimates/estimates-by-county-city-and-unincorporated-towns/. Accessed January 15, 2013.

Subramanian, K. H., 2007. Life Estimation of High Level Waste Tank Steel for F-Tank Farm Closure Performance Assessment, Rev. 1. Aiken, SC: Westinghouse Savannah River Company, WSRC-STI-2007-00061, Rev. 1.

Sullivan, T. M., 2003. Assessment of Release Rates for Radionuclides in Activated Concrete. Upton, NY: Brookhaven National Laboratory, BNL-71537-2003.

Tyler, S. W., J. B. Chapman, S. H. Conrad, D. P. Hammermeister, D. O. Blout, J. J. Miller, M. J. Sully, and J. M. Ginanni, 1996. Soil-Water Flux in the Southern Great Basin, United States: Temporal and Spatial Variation over the Last 120,000 Years. Water Resources Res. 32(6): 1481-1499.

U.S. Department of Energy, 1996. Land and Facility Use Planning. Washington, D.C.: U.S. Department of Energy, DOE P 430.1.

U.S. Department of Energy, 1997. Final Waste Management Programmatic Environmental Impact Statement for Managing, Treatment, Storage, and Disposal of Radioactive and Hazardous Waste, Vols. I-V. Washington, D.C.: U.S. Department of Energy, DOE/EIS-0200-F.

U.S. Department of Energy, 1998. Accelerating Cleanup: Paths to Closure. Washington, D.C.: U.S. Department of Energy, Office of Environmental Management, DOE/EM-0362, June 1998.

U.S. Department of Energy, 1999a. Radioactive Waste Management Manual. Washington, D.C.: U.S. Department of Energy, DOE M 435.1-1. 
U.S. Department of Energy. 1999b. From Cleanup to Stewardship, a Companion Report to Accelerating Cleanup: Paths to Closure. Washington, D.C.: U.S. Department of Energy, DOE/EM-0466, October 1999.

U.S. Department of Energy, 2001. Radioactive Waste Management. Washington, D.C.: U.S. Department of Energy, DOE O 435.1.

U.S. Department of Energy, 2003a. Environmental Protection Program. Washington, D.C.: U.S. Department of Energy, DOE O 450.1.

U.S. Department of Energy, 2003b. Use of Risk-Based End States. Washington, D.C.: U.S. Department of Energy, DOE P 455.1.

U.S. Department of Energy, 2008. Final Complex Transformation Programmatic Supplemental Environmental Impact Statement. Washington, D.C.: U.S. Department of Energy, DOE/EIS-0236-S4.

U.S. Department of Energy, 2011. Radiation Protection of the Public and the Environment. Washington, D.C.: U.S. Department of Energy, DOE O 458.1.

U.S. Department of Energy, National Nuclear Security Administration Nevada Operations Office, 2002. Performance Management Plan. Las Vegas, NV: DOE/NV--831, August 2002.

U.S. Department of Energy, National Nuclear Security Administration Nevada Site Office, 2006. Nevada Test Site Environmental Management End State Vision. Las Vegas, NV: DOE/NV--958, January 2006.

U.S. Department of Energy, National Nuclear Security Administration Nevada Site Office, 2008. Institutional Control of the Nevada Test Site. Las Vegas, NV: NSO P 454.X.

U.S. Department of Energy, National Nuclear Security Administration Nevada Site Office, 2011. Corrective Action Decision Document/Corrective Action Plan for Corrective Action Unit 98: Frenchman Flat, Nevada National Security Site, Nevada. Las Vegas, NV:

DOE/NV--1455, Rev. 1.

U.S. Department of Energy, Nevada Operations Office, 1996. Final Environmental Impact Statement for the Nevada Test Site and Off-Site Locations in the State of Nevada. Las Vegas, NV: U.S. Department of Energy, Nevada Operations Office, DOE/EIS 0243, August 1996.

U.S. Department of Energy, Nevada Operations Office, 1997. Focused Evaluation of Selected Remedial Alternatives for the Underground Test Area. Las Vegas, NV: DOE/NV--456.

U.S. Department of Energy, Nevada Operations Office, 1998a. Nevada Test Site Resource Management Plan. Las Vegas, NV: U.S. Department of Energy, Nevada Operations Office, DOE/NV--518. 
U.S. Department of Energy, Nevada Operations Office, 1998b. Accelerating Cleanup: Paths to Closure. Las Vegas, NV: U.S. Department of Energy, Nevada Operations Office, June 1998.

U.S. Department of Energy, Nevada Operations Office, 1998c. Consequences of Subsidence for the Area 3 and Area 5 Radioactive Waste Management Sites, Nevada Test Site. Las Vegas, NV: U.S. Department of Energy, Nevada Operations Office, DOE/NV--502.

U.S. Nuclear Regulatory Commission, 1981. Draft Environmental Impact Statement on 10 CFR Part 61 "Licensing Requirements for Land Disposal of Radioactive Waste." Washington, D.C.: U.S. Nuclear Regulatory Commission, NUREG-0782.

U.S. Nuclear Regulatory Commission, 1996. Regulatory Issues in Low-Level Radioactive Waste Performance Assessment. Washington, D.C.: U.S. Nuclear Regulatory Commission, SECY-96-103.

U.S. Nuclear Regulatory Commission, 2009. Staff Requirements - SECY-08-0147 - Response to Commission Order CLI-05-20 Regarding Depleted Uranium. Washington, D.C.: U.S. Nuclear Regulatory Commission, SECY-08-0147.

Virta, R. L., 2006. 2005 Minerals Yearbook, Zeolites. Washington, D.C.: U.S. Geological Survey, June 2006.

Walvoord, M. A., F. M. Phillips, S. W. Tyler, and P. C. Hartsough, 2002. Deep Arid System Hydrodynamics, 2. Application to Paleohydrologic Reconstruction Using Vadose Zone Profiles from the Northern Mojave Desert. Water Resources Res. 38(12): 271-276. 


\section{Distribution}

Jhon T. Carilli

Low-Level Waste Activities Lead

4 copies

U.S. Department of Energy

$1 \mathrm{CD}$

National Nuclear Security Administration

Nevada Site Office

P.O. Box 98518, M/S 505

Las Vegas, NV 89193-8518

Rob Boehlecke

Environmental Management Operations Manager

1 copy

U.S. Department of Energy

National Nuclear Security Administration

Nevada Site Office

P.O. Box 98518, M/S 505

Las Vegas, NV 89193-8518

U.S. Department of Energy

2 CDs

National Nuclear Security Administration

Nevada Site Office

Public Reading Facility

c/o Nuclear Testing Archive

P.O. Box 98521, M/S 400

Las Vegas, NV 89193-8521

U.S. Department of Energy

1 digital file

Office of Scientific and Technical Information

P.O. Box 62

Oak Ridge, TN 37831-0062

Bruce M. Crowe

1 copy

Navarro-Intera, LLC

P.O. Box 98592, M/S 505

Las Vegas, NV 89193-8518

Irene Farnham

1 copy

Navarro-Intera, LLC

P.O. Box 98592, M/S 505

Las Vegas, NV 89193-8518

Susan K. Krenzien

1 copy

Navarro-Intera, LLC

P.O. Box 98592, M/S 505

Las Vegas, NV 89193-8518 
Gregory J. Shott

1 сору

National Security Technologies, LLC

P.O. Box 98521, M/S NLV083

Las Vegas, NV 89193-8521

Vefa Yucel

1 copy

National Security Technologies, LLC

P.O. Box 98521, M/S NLV083

Las Vegas, NV 89193-8521 